UNIVERSIDADE ESTADUAL PAULISTA “JÚLIO DE MESQUITA FILHO” FACULDADE DE MEDICINA VETERINÁRIA E ZOOTECNIA CAMPUS DE BOTUCATU

\title{
EFEITO DOS ANTI-INFLAMATÓRIOS ESTERÓIDES NA REAÇÃO INFLAMATÓRIA E NA FERTILIDADE DE ÉGUAS NORMAIS E SUSCEPTÍVEIS À ENDOMETRITE PERSISTENTE APÓS INSEMINAÇÃO ARTIFICIAL
}

EDUARDO GORZONI FIORATTI

Botucatu - SP

Janeiro 2010 
UNIVERSIDADE ESTADUAL PAULISTA "JÚLIO DE MESQUITA FILHO” FACULDADE DE MEDICINA VETERINÁRIA E ZOOTECNIA CAMPUS DE BOTUCATU

\section{EFEITO DOS ANTI-INFLAMATÓRIOS ESTERÓIDES NA REAÇÃO INFLAMATÓRIA E NA FERTILIDADE DE ÉGUAS NORMAIS E SUSCEPTÍVEIS À ENDOMETRITE PERSISTENTE APÓS INSEMINAÇÃO ARTIFICIAL}

EDUARDO GORZONI FIORATTI

Dissertação apresentada junto ao Programa de Pós-Graduação em Medicina Veterinária para obtenção do título de Mestre em Reprodução Animal.

Orientador: Prof. Adj. Marco Antonio Alvarenga

Botucatu - SP

Janeiro 2010 
FICHA CATALOGRÁFICA ELABORADA PELA SEÇÃO TÉCNICA DE AQUISIÇÃO E TRATAMENTO DA INFORMAÇÃO

DIVISÃO TÉCNICA DE BIBLIOTECA E DOCUMENTAÇÃO - CAMPUS DE BOTUCATU - UNESP

BIBLIOTECÁRIA RESPONSÁVEL: Selma Maria de Jesus

Fioratti, Eduardo Gorzoni.

Efeito dos anti-inflamatórios esteróides na reação inflamatória e na fertilidade de éguas normais e susceptíveis à endometrite persistente após inseminação artificial / Eduardo Gorzoni Fioratti. - Botucatu : [s.n.], 2010

Dissertação (mestrado) - Universidade Estadual Paulista, Faculdade de Medicina Veterinária e Zootecnia, Botucatu, 2010

Orientador: Marco Antonio Alvarenga

Assunto CAPES: 50504002

$\begin{array}{lll}\text { 1. Eqüino - Reprodução } & \text { 2. Endometrite } \quad 3 . \text { Inseminação artificial }\end{array}$

CDD 636.10824

Palavras-chave: Antiinflamatório esteróide; Dexametasona; Égua; Endometrite 
Nome do autor: Eduardo Gorzoni Fioratti

Título: EFEITO DOS ANTI-INFLAMATÓRIOS ESTERÓIDES NA REAÇÃO INFLAMATÓRIA E NA FERTILIDADE DE ÉGUAS NORMAIS E SUSCEPTÍVEIS À ENDOMETRITE PERSISTENTE APÓS INSEMINAÇÃO ARTIFICIAL.

\section{COMISSÃO EXAMINADORA}

Prof. Adjunto Marco Antonio Alvarenga

Orientador

Departamento de Reprodução Animal e Radiologia Veterinária FMVZ - UNESP - Botucatu

Profa. Adjunto Maria Denise Lopes

Departamento de Reprodução Animal e Radiologia Veterinária FMVZ - UNESP - Botucatu

Prof. Doutor Rubens Paes de Arruda

Departamento de Reprodução Animal

FMVZ - USP - Pirassununga

Botucatu, 27 de janeiro de 2010 


\section{AGRADECIMENTOS}

Não tenho palavras para agradecer ao meu pai Eduardo (in memorian) e minha mãe Oneide que foram minha maior inspiração, que sempre acreditaram em mim e me deram força nos momentos em que precisei e me deram freio nos momentos em que extrapolei. Agradeço por minha educação e caráter.

Não consigo exprimir o quanto sou grato ao professor Marco Antonio Alvarenga, meu orientador, que contribuiu de maneira ímpar para minha qualificação profissional e sempre manteve a calma para me instruir em momentos de dúvida. Agradeço por compartilhar comigo suas experiências e conhecimentos.

Impossível não mencionar a atenção e ajuda sempre precisa do professor Frederico Ozanam Papa e da professora Maria Clara Caldas Bussiere.

Agradecimento especial deve ser dado aos veterinários Marcelo Pessoa, André e Gabriel, pois sem eles esse projeto jamais teria saído do papel.

Não posso esquecer de gratificar minha namorada Ana Izabel por estar sempre presente me dando apoio com seu sorriso, seu olhar, com seu carinho. Agradeço a nossa sintonia e cumplicidade.

Não se pode mensurar as amizades que aqui conquistei, por isso seria injusto de minha parte citar nomes. No processo de meu amadurecimento todos meus amigos têm enorme mérito, pois estiveram envolvidos em cada etapa. Agradeço-os por me deixar compartilhar de suas vidas e experiências.

Não posso deixar de dizer que cada professor foi, para mim, um novo pai, exercendo as funções de ensinar, reprimir, orientar e conduzir-me nos caminhos da qualificação e capacitação profissional. Agradeço a cada um de vocês, detentores do conhecimento por comigo compartilhá-lo. 
Não podemos esquecer dos animais, razão de nosso trabalho. Obrigado

Não se pode esquecer de agradecer a Deus pela minha família, minha saúde e meus amigos, pelo otimismo e crença na minha profissão. Obrigado.

À FAPESP, pelo apoio financeiro.

Agradeço a todos aqueles que por algum motivo tentaram me derrubar, atrasar e atrapalhar minha vida, a esses digo muito obrigado. Agradeço-os, pois na fraqueza de vocês é que me fortaleço.

A todos vocês muito OBRIGADO. 
"Pedi a Deus, para ser forte a fim de executar projetos grandiosos, e Ele me fez fraco para conservar-me humilde.

Pedi a Deus que me desse saúde para realizar grandes empreendimentos, e Ele deu-me a doença para compreendêe-lo melhor.

Pedi a Deus riqueza, para tudo possuir, e Ele deixou-me pobre para não ser egoísta.

Pedi a Deus poder, para que os homens precisassem de mim, e Ele deu-me a humildade para que $d$-Ele precisasse. Pedi a Deus tudo para gozar a vida, e Ele me deu a vida para gozar de tudo.

Senhor, não recebi nada do que pedi, mas deste-me tudo que eu precisava.

E, quase contra a minha vontade, as preces que não fiz foram ouvidas. Louvado seja ó meu Deus! entre todos os homens NISGUÉM TEM MAIS DO QUE EU! 


\section{LISTA DE TABELAS}

\section{TRABALHO 1}

TABELA 1. Valores de dose, $\mathrm{pH}$ e osmolaridade mensurados no diluidor de sêmen equino após adição de 15 anti-inflamatórios esteróides .....30

TABELA 2. Valores médios e desvios padrão das características de movimento espermático nos momentos 0 e 30 minutos após a diluição das amostras de sêmen equino com diluidor contendo corticóides e grupo controle $(n=20)$ 31

TABELA 3. Valores médios e desvios padrão das características de movimento espermático nos momentos 60 e 120 minutos após a diluição das amostras de sêmen equino com diluidor contendo corticóides e grupo controle $(n=20)$ 32

TABELA 4. Valores médios e desvios padrão para motilidade progressiva e porcentagem de espermatozóides rápidos nos momentos $0,30,60$ e 120 minutos após a diluição das amostras de sêmen equino em diluente controle e adicionado com dexametasona $(n=8)$ 33

\section{TRABALHO 2}

TABELA 1. Valores médios \pm desvios padrão da concentração de neutrófilos/ $\mathrm{mL}$ de fluído uterino recuperado de éguas resistentes e susceptíveis após a inseminação artificial .55 
TABELA 2. Porcentagem de redução de neutrófilos entre os momentos 8 e 24 horas após a inseminação artificial de éguas resistentes e susceptíveis a endometrite persistente pós cobertura .55

TABELA 3. Porcentagem de neutrófilos uterinos funcionais coletados 8 e 24 horas após a inseminação artificial de éguas resistentes e susceptíveis a endometrite persistente pós cobertura .57

TABELA 4. Valores médios $(\mathrm{mm})$ e porcentagem de redução (\%) da altura da coluna de líquido acumulado na região da bifurcação uterina de éguas susceptíveis a endometrite persistente pós cobertura 8 e 24 horas após a inseminação 58

\section{TRABALHO 3}

TABELA 1. Valores médios \pm desvio padrão da concentração de neutrófilos/ $\mathrm{mL}$ de fluído uterino recuperado de éguas resistentes e susceptíveis após a inseminação artificial .83

TABELA 2. Porcentagem de redução de neutrófilos entre os momentos 8 e 24 horas após a inseminação artificial de éguas resistentes e susceptíveis a endometrite persistente pós cobertura .84 


\section{LISTA DE FIGURAS}

\section{TRABALHO 2}

FIGURA 1. Porcentagem de neutrófilos observados em exame citológico ao longo do tempo analisado para as éguas resistentes a endometrite persistente pós cobertura .56

FIGURA 2. Porcentagem de neutrófilos observados em exame citológico ao longo do tempo analisado para as éguas susceptíveis a endometrite persistente pós cobertura .56

FIGURA 3. Média dos valores do volume de fluído uterino recuperado $(\mathrm{mL})$ pelo tampão de algodão as 8 e as 24 horas após a inseminação artificial de éguas resistentes e susceptíveis a endometrite persistente pós cobertura .59

FIGURA 4. Porcentagem de embriões recuperados de éguas resistentes e susceptíveis a endometrite persistente pós cobertura .59

\section{TRABALHO 3}

FIGURA 1. Valores médios para a concentração de óxido nítrico mensurada no fluído uterino livre de éguas resistentes e susceptíveis para os grupos controle $(C)$, tratado local (TL) e tratado sistêmico (TS) nos momentos 8 e 24 horas após a inseminação artificial .85 


\title{
LISTA DE ABREVIAÇÕES E SIGLAS
}

\author{
$\mathrm{ALH}=$ Deslocamento lateral da cabeça \\ ${ }^{\circ} \mathrm{C}=$ graus centígrados \\ $\mathrm{cm}=$ Centímetro \\ COX = Ciclooxigenase \\ eNOS = óxido nítrico-sintetase endotelial \\ EPPC $=$ Endometrite Persistente Pós -Cobertura
}

FITC-PSA = Glutinina de Psium sativum conjugada a fluoresceína isotiocianato

$g=$ gravidade

IA = Inseminação artificial

$\mathrm{IL}=$ interleucina

$\mathrm{IM}=$ Intramuscular

IMP = Integridade de membrana plasmática

iNOS = óxido nítrico-sintetase indutora

IP = lodeto de propídio

JC-1 = lodeto de 5,5',6,6'-tetracloro-1,1,3,3'-tetraetilbenzimidazolilcarbocianina

$\mathrm{Kg}=$ Quilograma

LIN = Linearidade

$\mathrm{M}=$ Molar

$\mathrm{mg}=$ Miligrama

$\mathrm{mm}=$ milímetros

$\mathrm{mL}=$ mililitros

$\mathrm{mOsm}=$ Miliosmol

$\mathrm{MP}=$ Motilidade progressiva

MT = Motilidade total

$\mathrm{nm}=$ Nanometro

$\mathrm{NO}_{2}^{-}=$nitrito

$\mathrm{NO}_{3}^{-}=$nitrato

NOS = óxido nítrico-sintetase 
nNOS = óxido nítrico-sintetase neuronal

$\mathrm{ON}=$ óxido nítrico

PBS = phosphate buffered saline

$\mathrm{PGF}_{2 \alpha}=$ prostaglandina $\mathrm{F} 2$ alfa

PMNs = neutrófilos polimorfonucleares

STR = Índice retilíneo

$\mathrm{TL}=$ tratado local

TS $=$ tratado sistêmico

VAP $=$ Velocidade espermática ao longo de uma trajetória média

$\mathrm{VCL}=$ Velocidade espermática ao longo da trajetória real

VSL = Velocidade ao longo de uma linha reta

$\mu \mathrm{L}=$ Microlitro

$\mu \mathrm{m}=$ Micrometro

$\mu \mathrm{M}=$ micromolar 


\section{SUMÁRIO}

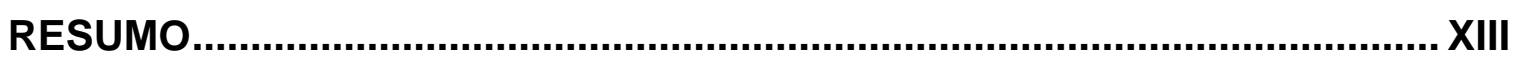

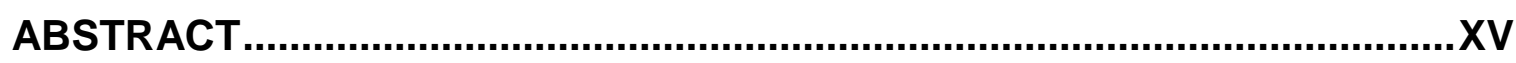

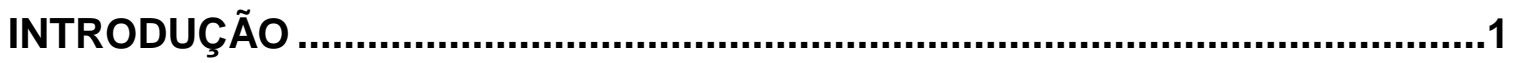

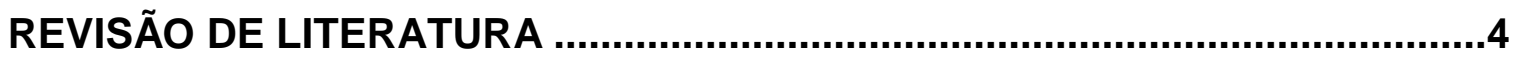

1. ETIOPATOGENIA DA ENDOMETRITE PERSISTENTE PÓS-COBERTURA...............................5

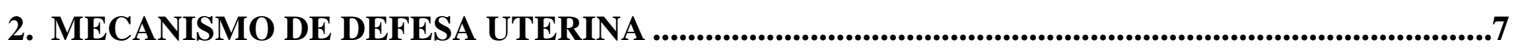

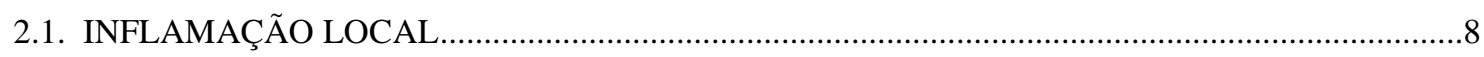

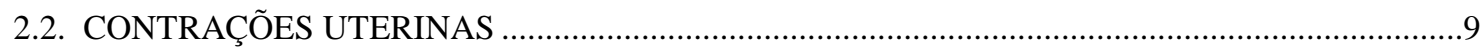

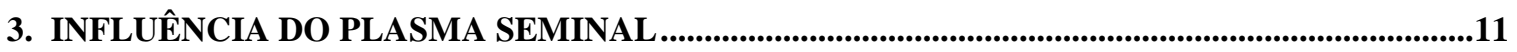

4. TERAPIA APLICADA A ENDOMETRITE PERSISTENTE PÓS-COBERTURA..........................13

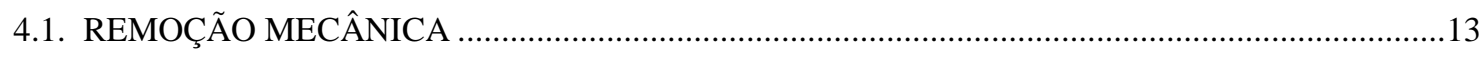

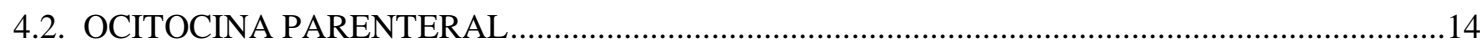

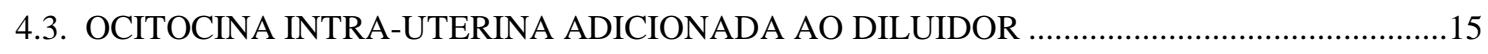

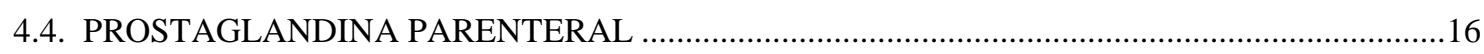

4.5. PROSTAGLANDINA INTRA-UTERINA ADICIONADA AO DILUIDOR …………………........17

4.6. ANTIINFLAMATÓRIOS NÃO ESTEROIDAIS SISTÊMICOS ….................................................18

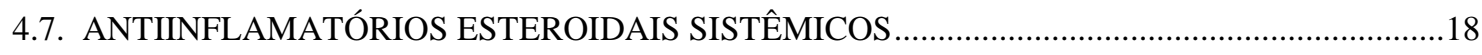

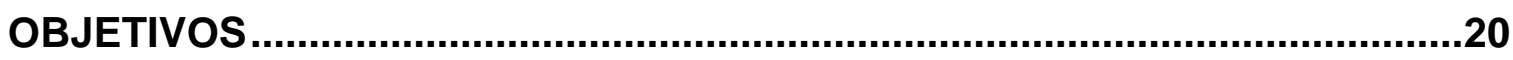

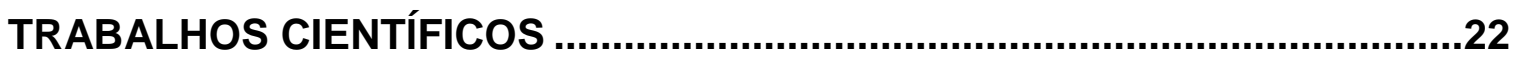

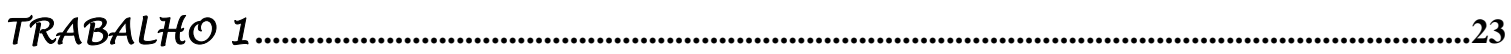

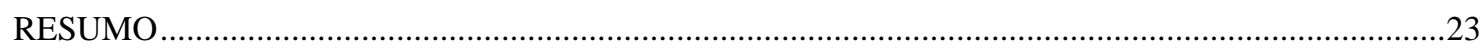

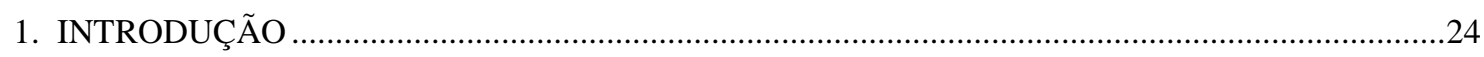

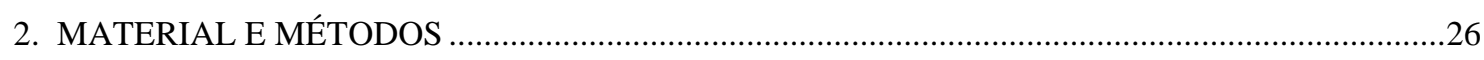

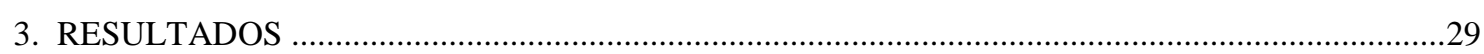




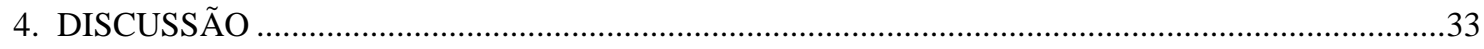

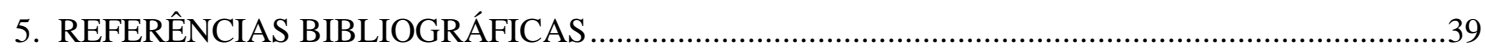

TRABALHO 2

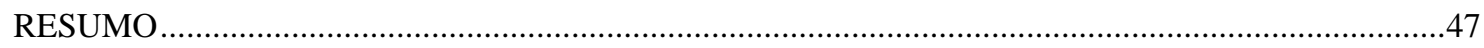

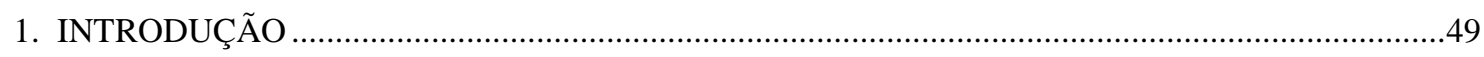

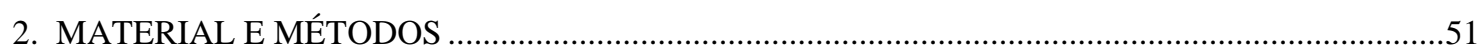

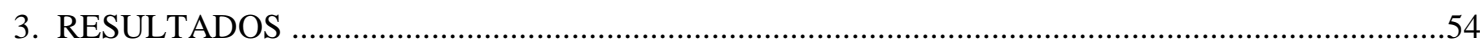

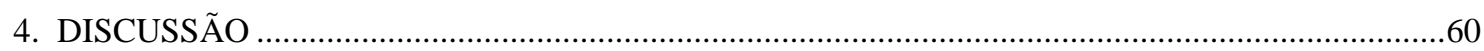

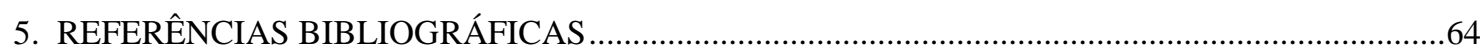

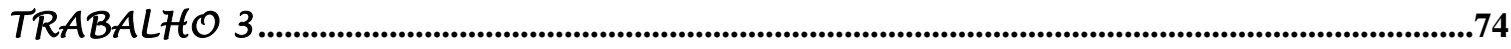

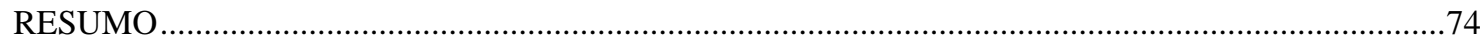

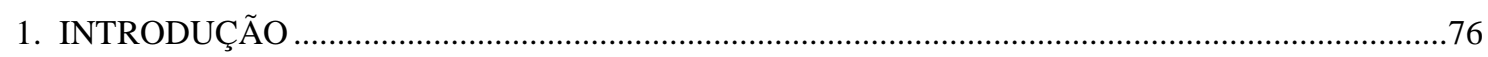

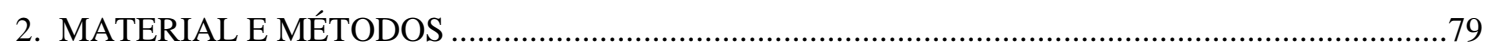

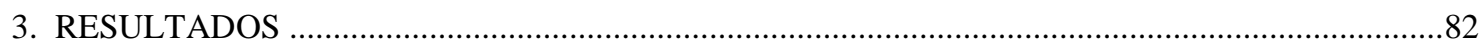

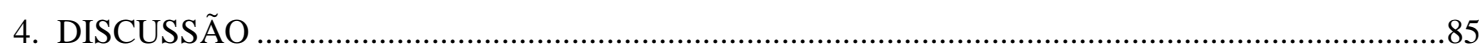

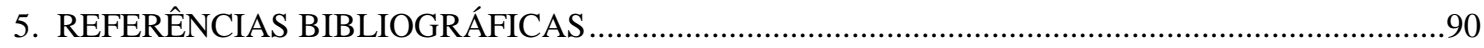

DISCUSSÃO GERAL.................................................................................. 98

CONCLUSÕES GERAIS ...........................................................................104

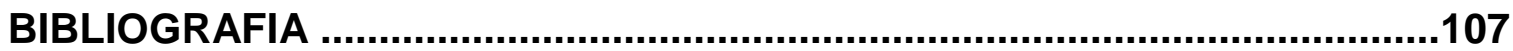




\section{RESUMO}

FIORATTI, EDUARDO GORZONI. Efeito dos antiinflamatórios esteróides na reação inflamatória e na fertilidade de éguas normais e susceptíveis à endometrite persistente após inseminação artificial. Botucatu, 2010. 118p. Dissertação de mestrado. Universidade Estadual Paulista "Júlio de Mesquita Filho", Faculdade de Medicina Veterinária e Zootecnia, Campus de Botucatu.

O objetivo deste estudo foi verificar a influência da adição de antiinflamatórios esteróides (AIES) ao diluidor seminal na motilidade e funcionalidade espermática e a eficiência da dexametasona na imunomodulação da resposta inflamatória após a cobertura. A dexametasona foi selecionada entre quinze diferentes AIES. Foram analisadas a motilidade (CASA), a integridade da membrana plasmática e acrossomal e o potencial da membrana mitocondrial dos espermatozóides nos momentos zero, 30, 60 e 120 minutos após a diluição. A intensidade da reação inflamatória provocada pelo sêmen foi mensurada em éguas resistentes e susceptíveis à endometrite persistente pós cobertura utilizando exame ultrassonográfico e citologia exfoliativa do útero, concentração de neutrófilos e de óxido nítrico do fluído uterino e taxa de recuperação embrionária. Dentre os AIES testados a dexametasona foi a que apresentou menor efeito deletério sobre as caracteísticas de motilidade e na morfofuncionalidade espermática. Quinze éguas resistentes e 15 susceptíveis à endometrite persistente após cobertura foram submetidas ao tratamento com dexametasona sistêmica e intra uterina adicionada ao diluidor de sêmen. As éguas susceptíveis apresentaram resposta inflamatória mais intensa durante as primeiras 8 horas após a inseminação artificial $(p<0,05)$, porém, após 24 horas as concentrações de óxido nítrico foram semelhantes entre as éguas resistentes e susceptíveis, apesar das éguas susceptíveis manterem a reação inflamatória mais intensa até esse momento $(p<0,05)$. As taxas de recuperação embrionária foram maiores para as éguas resistentes do que para as susceptíveis $(p<0,05)$. Os tratamentos com dexametasona não se mostraram eficazes na imunomodulação da resposta inflamatória induzida pela cobertura. 
Palavras-chave: égua, endometrite, anti-inflamatório esteróide, dexametasona. 


\begin{abstract}
FIORATTI, EDUARDO GORZONI. Effect of anti-inflammatory steroids on the inflammatory reaction and fertility of normal and susceptible post-breeding endometritis mares. Botucatu, 2010. 118p. Dissertação de mestrado. Universidade Estadual Paulista "Júlio de Mesquita Filho", Faculdade de Medicina Veterinária e Zootecnia, Campus de Botucatu.
\end{abstract}

The objective of this study was to assess the influence of the addition of anti-inflammatory steroids (AIS) in the seminal extender in sperm viability and functionality, and efficiency of dexamethasone on immune modulation of inflammatory response after mating. Dexamethasone was selected from fifteen different AIS. Motility, membrane and acrosomal integrity and mitochondrial membrane potential of spermatozoa in moments 0, 30, 60 e 120 minutes after dilution were analyzed. The intensity of the inflammatory reaction caused by sperm was measured in resistant and susceptible mares using ultrasound examination and exfoliative cytology of the uterus, concentration of neutrophils and nitric oxide in uterine fluid and rate of embryo recovery. Among the AIS tested dexamethasone maintained the sperm motility parameters and did not show any deleterious effects on sperm structure and function ( $p>0.05)$. Fifteen mares resistant and 15 susceptible to post-breeding endometritis were subjected to treatment with dexamethasone systemic and intra uterine added to the semen extender. Susceptible mares showed more severe inflammatory response during the first 8 hours after artificial insemination $(p<0.05)$, while 24 hours after mating the concentrations of nitric oxide were similar between resistant and susceptible mares, despite the fact that susceptible mares presented inflammatory reaction more intensive in this moment $(p<0.05)$. The embryo recovery rates were higher for mares resistant compared to susceptible $(p<0.05)$. Treatments with dexamethasone were not effective in the immunomodulation of the inflammatory response induced by mating.

Keywords: mare, endometritis, anti-inflammatory steroid, dexamethasone 
Jutrodusão 


\section{INTRODUÇÃO}

Visando a maximização da eficiência reprodutiva de um sistema de criação de eqüinos, é essencial trabalhar para a obtenção de um produto por ano de todas as éguas do rebanho. Para isso é necessária a integração entre os aspectos fisiológicos, nutricionais e de manejo. Contudo, apesar de toda a evolução que a reprodução animal tem alcançado nas últimas décadas, especialmente na área de biotecnologia, as desordens de origem uterina continuam causando grande prejuízo econômico. A maioria dessas desordens tem efeito deletério sobre a atividade ovariana, taxa de concepção, número de serviços por concepção e sobrevivência embrionária. As desordens uterinas também levam a um aumento no intervalo entre partos, nos gastos devido à necessidade de tratamentos muitas vezes insatisfatórios e no risco de descarte de animais de alto valor genético.

Dentre as desordens uterinas que acometem as éguas destaca-se a endometrite, condição que envolve inflamação e muitas vezes, por conseqüência, infecção do endométrio das éguas, sendo uma das causas mais importantes e freqüentes de infertilidade e de baixa eficiência reprodutiva (THOMASSIAN, 1996; CARD, 1997; NIKOLAKOPOULOS \& WATSON, 1999; TROEDSSON, 1999). Considerando-se o processo de endometrite, as éguas classificadas como susceptíveis são aquelas que apresentam falha no processo de limpeza uterina associada a uma migração exacerbada de polimorfonucleares (PMNs) para o útero. Essas alterações resultam em uma resposta inflamatória exacerbada, com contínua migração de neutrófilos atraídos pela quimiotaxia originada pela presença dos espermatozóides, desta forma, tornando o ambiente uterino incompatível com o desenvolvimento embrionário (TROEDSSON, 1999).

Atualmente a presença de mais de 2 centímetros de fluido uterino, durante a fase de estro, tem sido considerada como o fator principal para a detecção precoce daqueles animais considerados susceptíveis à endometrite persistente pós-cobertura (EPPC) (BUCCA et al., 2008). O fluido uterino pode estar livre no lúmen uterino ou encapsulado por um tecido cicatricial fibrótico, 
esse ponto de acúmulo de líquido torna o útero mais susceptível às infecções e impossibilita a implantação embrionária (LEFRANC \& ALLEN, 2008).

A luteólise prematura e o efeito tóxico desse conteúdo uterino sobre 0 embrião também são responsáveis pela baixa fertilidade nas éguas susceptíveis, que representam aproximadamente $15 \%$ dos animais em atividade reprodutiva (ZENT \& TROEDSSON, 1998). Os tratamentos empregados para a EPPC são geralmente ineficientes e podem resultar em agravamento dos sinais clínicos e baixas taxas de prenhes com substanciais perdas econômicas se não forem devidamente utilizados. 


\section{Revisão de literatura}




\section{REVISÃO DE LITERATURA}

\section{Etiopatogenia da endometrite persistente pós-cobertura}

A infecção do trato reprodutivo ocorre normalmente em processos como cobertura, parto e durante exames realizados pelo médico veterinário. No entanto, a mucosa do trato reprodutivo possui um sistema imune pelo qual bactérias, fungos, sêmen e contaminantes como fezes e urina são retirados do útero por uma combinação entre os fatores celulares e humorais. Além disso, mecanismos de drenagem física também atuam na limpeza do ambiente uterino. Quando existe falha ou incompetência em qualquer um desses mecanismos naturais de defesa, a endometrite pode se instalar levando à infertilidade (ASBURY, 1986; ASBURY, 1987; LEBLANC, 2003).

A monta natural e a inseminação artificial (IA) são consideradas como causa principal de endometrite. Devido à existência de uma pressão uterina negativa, responsável pela deposição do sêmen dentro do útero da égua, muitas bactérias da flora normal da vagina são deslocadas para o interior do útero no momento da cópula (HINRICHS et al., 1988). Com o advento da IA e com a utilização de diluentes para o sêmen contendo antibiótico, uma grande redução no número de éguas contaminadas foi observada. Contudo, apesar da menor quantidade de espermatozóides depositados no útero comparado à monta natural, após a IA um grande número de leucócitos ainda é observado, uma vez que a presença das células espermáticas é o principal fator para a indução da resposta inflamatória local (Dell'aqua Jr., 2004).

A EPPC é uma inflamação fisiológica e transitória que serve para limpeza do excesso de espermatozóides mortos e de outros contaminantes uterinos formados pela deposição do sêmen. A inflamação é causada pela presença das células espermáticas no útero e caracteriza-se por uma rápida infusão de neutrófilos uma hora após a inseminação artificial (CARD, 2005; TROEDSSON et al., 1998; TROEDSSON, 1999).

Nas éguas, tanto as células espermáticas quanto o plasma seminal no interior do útero são capazes de ativar o mecanismo inflamatório, em níveis 
diferentes de importância entre eles. Através da quimiotaxia, os espermatozóides promovem massiva invasão de PMNs no lúmen uterino, os quais desencadeiam um processo de inflamação e de fagocitose das células espermáticas. Essa inflamação leva a liberação de PGF2a causando contrações miometriais, que são essenciais para a limpeza uterina. Dessa forma, a inflamação induzida pela presença do espermatozóide pode ser considerada como a causa mais importante de infertilidade nas éguas susceptíveis a EPPC (TROEDSSON, 1997, TROEDSSON et al., 2001).

Após trinta minutos do contato do espermatozóide com o útero o sêmen é transportado em um processo rápido através de contrações miometriais do corpo e dos cornos uterinos até o sítio de fertilização. Após quatro horas da IA, a maioria dos espermatozóides no interior do lúmen uterino deve ser eliminada (CAMPBELL \& ENGLAND, 2006). Contudo, nas éguas susceptíveis, devido a uma diminuição da contratilidade uterina, há um maior acúmulo de líquido no interior do útero quando comparadas com as resistentes a EPPC que pode atuar como meio de cultura para agentes oportunistas agravando o quadro de endometrite. Normalmente, as éguas devem controlar essa inflamação dentro de 24 a 36 horas, uma vez que este ambiente uterino desfavorável pode levar a um comprometimento do desenvolvimento embrionário (TROEDSSON, 1999; LEBLANC, 2003). O embrião deixa a tuba uterina em torno do quinto dia pósovulação e, assim sendo, a inflamação uterina deve ser controlada até 96 horas pós-ovulação para não interferir com a sobrevivência do embrião (CARD, 2005).

Nas éguas susceptíveis há redução na freqüência, intensidade e duração da atividade miometrial, possivelmente devido a mudanças na liberação, sistêmica ou local, de uterotoninas, assim como prostaglandinas e ocitocinas; pela produção alterada de substâncias neuromusculares ou vasoativas que afetam a atividade miometrial ou por mudanças intrínsecas na musculatura uterina promovendo uma incapacidade de responder aos estímulos de contração (RIGBY et al., 2001).

A EPPC é, normalmente, causada por alterações degenerativas que ocorrem continuamente no útero de éguas em resposta à idade e ao número de partos. A perda do suporte estrutural do trato reprodutivo através do estiramento dos ligamentos largos em decorrência de prenhezes repetidas 
resultam no deslocamento cranial e ventral do útero para o abdome, desta forma dificultando a drenagem do fluído do lúmen uterino através da cérvix. Portanto, geralmente os animais afetados são fêmeas multíparas e com mais de 14 anos de idade. (LEBLANC, 2003). Outros fatores de predisposição à EPPC são o acúmulo de fluido endometrial antes da IA maior que 2 centímetros, a conformação perineal anormal e uma cérvix incompetente. Os animais acometidos pela EPPC podem apresentar histórico de repetição de cio, cultura endometrial positiva além do acúmulo de fluido endometrial persistente após a IA (BUCCA et al., 2008).

Mediante tantas variáveis, o diagnóstico definitivo da EPPC deve ser feito através de exame completo do trato reprodutivo. A palpação retal pode revelar um útero anormalmente flácido e com acúmulo de líquido. No exame utilizando o espéculo observam-se sinais de inflamação por toda a vagina. Adicionalmente, no exame de citologia uterina é comum o achado de grande número de neutrófilos e, normalmente, bactérias não são isoladas de swabs uterinos de éguas com EPPC (LEBLANC, 2003).

\section{Mecanismo de defesa uterina}

O ambiente uterino sadio oferece as condições ideais para que ocorra inicialmente o transporte espermático ao sítio de fecundação e, posteriormente, o desenvolvimento embrionário. O fluido uterino é composto por hormônios, prostaglandinas, enzimas, substratos energéticos, íons, vitaminas, aminoácidos, peptídeos e proteínas séricas, sendo formado pelo extravasamento de componentes do sangue pelo endométrio e por substâncias intra-uterinas (FISCHER \& BEIER, 1986; MCRAE, 1988). 


\subsection{Inflamação local}

O processo inflamatório agudo se caracteriza por ocorrer poucas horas após a agressão, apresentando cinco características básicas: calor, dor, tumor, rubor, e perda da função do local afetado. Imediatamente após a instalação da injúria, ocorre uma constrição das arteríolas e dilatação de todas as vênulas da região afetada, resultando num aumento de fluxo de sangue para o local. Poucas horas depois, ocorre uma diminuição gradual deste afluxo sangüíneo, retornando aos valores normais. Com a dilatação das vênulas há um aumento da permeabilidade vascular, fazendo com que um exsudato extravase para o tecido agredido, ocasionando um edema local. Com o início das alterações vasculares, células de defesa como neutrófilos, eosinófilos e monócitos se aderem ao endotélio dos vasos e se existirem danos vasculares as plaquetas irão se aglutinar nessa região lesada para conter a hemorragia. Após a aderência das células de defesa na parede dos vasos, os leucócitos começam a migrar para o tecido agredido, os neutrófilos e os eosinófilos são os primeiros a transpor a parede vascular, devido a sua maior mobilidade no sangue (COLLINS et al, 1999).

Uma intensa reação inflamatória ocorre entre 4 e 24 horas após 0 contato do sêmen com útero (CARD, 2005; RIGBY et al., 2001). Em fêmeas com um sistema de defesa funcional, a maioria dos produtos inflamatórios é removida do útero dentro de 24 a 36 horas após a contaminação (ASBURY, 1986; LEBLANC, 2003; THOMASSIAN, 1996; TROEDSSON, 1999).

O mecanismo celular é representado principalmente pelos neutrófilos, os quais constituem a primeira linha de defesa do organismo, e são atraídos por quimiotaxia por vários mediadores inflamatórios, atuando na eliminação de antígenos através de fagocitose (ASBURY, 1986; GALINDO et al., 2003). Adicionalmente, a segunda linha de defesa são os macrófagos que, ao contrário dos neutrófilos, são capazes de realizar atividade fagocítica prolongada e repetida, além de secretarem moléculas que amplificam a resposta imune, controlarem a inflamação e contribuírem diretamente para o reparo tecidual através da remoção do tecido danificado (TIZARD, 1998).

O útero responde rapidamente a presença de um antígeno com liberação de mediadores quiumiotáticos resultando em um rápido influxo de 
PMNs para o lúmen uterino, produtos inflamatórios complementares como o leucotrieno (LTB4), prostaglandina $E$, prostaglandina $F_{2} \alpha$ e interleucina (IL-8) são quimiotáticos para os PMNs. O sistema complemento é mediador de reações de defesa uterina atuando no aumento da permeabilidade vascular, quimiotaxia, opsonização pré fagocitose, ativação de lipases de membrana e lise do organismo alvo (TROEDSSON et al., 2008).

O processo inflamatório crônico ocorre muitas horas após os neutrófilos atingirem o foco da inflamação. Os monócitos são atraídos para o sítio da inflamação pela presença dos neutrófilos, colágeno, elastina, fibrinogênio e linfocinas. Enquanto os macrófagos fagocitam o tecido danificado, os neutrófilos e o fibrinogênio liberam as colagenases e elastases que atuam sobre o tecido conjuntivo. As interleucinas I, atraídas pelos macrófagos, ativam a síntese dos fibroblastos que produzem o colágeno responsável por reparar o tecido danificado, resultando em tecido cicatricial (COLLINS et al., 1999). As citocinas, proteínas secretadas pelos macrófagos, são responsáveis pela atração e potencialização de linfócitos, as células que mediam a resposta imune (TIZARD, 1998).

Muitas classes e subclasses de imunoglobulinas (IgGa, IgGb, IgGc, $\lg G T, \lg A, \lg M)$ já foram isoladas do útero eqüino, sendo a imunoglobulina predominante no muco cervicovaginal a $\lg A$ e no lúmen uterino a $\lg G$ (THRELFALL \& CARLETON, 1986; THRELFALL \& IMMEGART, 2000; TROEDSSON, 1999). A transudação passiva de imunoglobulinas para a luz uterina é mínima, sendo as $\lg G$ e $\lg A$ produzidas localmente pelo trato genital. Embora a defesa uterina mediada por anticorpos seja um fator importante na eliminação de contaminantes bacterianos do útero, a eficiência dessa defesa não depende somente desses fatores humorais (TROEDSSON, 1999), já que não há alteração na concentração de IgA após a IA o fator mais importante na defesa uterina é a resposta celular (DELL'AQUA Jr. et al., 2006).

\subsection{Contrações uterinas}

O papel das contrações uterinas é remover os produtos inflamatórios, que muitas vezes tornam-se nocivos para o endométrio, e expulsar debris 
resultantes da lesão tecidual e da morte celular (GALINDO et al., 2003; TROEDSSON, 1999).

A atividade contrátil uterina é conseqüência da despolarização e repolarização da membrana plasmática das células do músculo liso uterino. Há uma região do miométrio do corno uterino que inicia o pulso contrátil em direção a cérvix; essa região nas éguas susceptíveis aparece mais frequentemente no corpo uterino. Essa localização pode ser advinda de uma hipertrofia por seguidas prenhezes ou por um fator intrínseco dessas éguas. Em um estudo in vitro, foi observado que o útero de éguas susceptíveis exibe uma disfunção contrátil do miométrio. Um defeito na sinalização neuronal pode também contribuir para o mau funcionamento contrátil do miométrio (REITZENSTEIN et al., 2002).

Éguas não susceptíveis apresentam contrações uterinas em maior número, mais prolongadas e com maior intensidade comparadas às éguas susceptíveis, uma vez que apresentam um padrão de propagação contrátil do corno ao corpo do útero, ao contrário das éguas susceptíveis que exibem um padrão de propagação da contração invertido ou simultâneo (REITZENSTEIN et al., 2002).

Contrações uterinas durante e após o coito são, provavelmente, responsáveis pela movimentação passiva do espermatozóide até o oviduto, não estando este mecanismo bem esclarecido na espécie eqüina (TROEDSSON et al., 1998). Campbell \& England (2004) sugerem que o estímulo mecânico da vagina e da cérvix, assim como o volume de fluido depositado no útero podem ser fatores determinantes. Nikolakopoulos et al. (2000) relataram que a cobertura, o estímulo mecânico da vagina e da cérvix e a distensão uterina geralmente causam aumento na concentração plasmática de ocitocina e, portanto, um aumento nas contrações miometriais, sem necessariamente afetar as concentrações plasmáticas dos metabólitos da prostaglandina (PGF2 $\alpha$ ).

Por medições ultrassonográficas constatou-se que o número total, a amplitude média e a duração média das contrações dos cornos uterinos não dependem do lado onde ocorre a ovulação, no entanto, a monta natural pode aumentá-los significativamente em todas as regiões do útero sem alterar a direção dessas contrações, com aproximadamente metade sendo no sentido 
cervico-tubárico e a outra metade no sentido contrário (Campbell \& England, 2006).

Em contrapartida, o óxido nítrico $(\mathrm{ON})$, um subproduto do processo inflamatório produzido por macrófagos, neutrófilos, células epiteliais e endoteliais, é encontrado no fluido uterino após a cobertura causando relaxamento do miométrio. $\mathrm{O} \mathrm{ON}$ tem sido identificado como um importante mensageiro intra e intercelular que controla vários processos, como o tônus vascular, a neurotransmissão, produção de hormônios, diferenciação celular, expressão gênica, a ativação de células do sistema imune e na fisiologia ovariana (MOIRA et al., 1998). A concentração de ON não difere com a utilização de sêmen fresco ou congelado e encontra-se em menor concentração nas éguas resistentes a EPPC do que nas susceptíveis (ALGHAMDI \& TROEDSSON, 2002).

Alghamdi et al. (2005) propõe ainda, que o óxido nítrico como mediador do relaxamento da musculatura lisa é responsável por manter a atividade mioelétrica abaixo da linha basal entre 7 e 19 horas do início do processo inflamatório nas éguas susceptíveis a EPPC.

\section{Influência do plasma seminal}

A influência do volume inseminante e, portanto, da quantidade de plasma seminal introduzido no útero sobre as contrações uterinas permanece como fonte de contradição entre diversos autores. Troedsson et al. (1998) constataram um aumento no número total, na amplitude e na duração das contrações uterinas ao compararem o volume inseminante de 80 e de $10 \mathrm{~mL}$. Em contrapartida, Sinnemaa et al. (2005) e Campbell \& England (2006) não encontraram diferença nas IA realizadas com 2 ou $100 \mathrm{~mL}$. A redução nas contrações, observada com o volume de $10 \mathrm{~mL}$, pode ser resultante da menor quantidade de PGF2 $\alpha$ (BIELANSKI et al., 1982) e ocitocina (WATSON et al., 1999) presentes no sêmen.

A ocitocina, detectada em todas as frações do ejaculado de garanhões, apresenta maiores concentrações na fração gel, a qual é removida para a realização da IA. O plasma seminal é também rico em prostaglandinas, 
responsáveis por induzir contrações uterinas e, por conseqüência, minimizar o processo inflamatório após a IA. No plasma seminal de garanhões encontra-se $14,5 \mathrm{ng} / \mathrm{ml}$ de PGF2 $\alpha$ sendo responsável por induzir contrações uterinas e por conseqüência minimizar o processo inflamatório após a cobertura (CLAUS et al., 1992; O'Bert et al., 2006).

Observações sugerem que enquanto o sêmen de determinados garanhões provoca uma reação inflamatório exacerbada, o sêmen de outros é responsável por uma resposta inflamatória mais branda independente da égua ser ou não susceptível à EPPC (TROEDSSON et al., 2000, TROEDSSON et al., 2002).

O plasma seminal tem sido considerado como agente supressor da atividade do sistema complemento, e por sua vez da quimiotaxia pelos PMNs e fagocitose, atuando como inibidor ou modulador da inflamação uterina (TROEDSSON et al., 2000). A duração dessa inflamação é reduzida quando o plasma seminal está presente na dose inseminante do que quando ele é removido ou substituído por extensor (TROEDSSON et al., 2002). O número de PMNs encontrado no útero 24 horas após a IA foi significativamente menor quando o plasma seminal foi mantido na inseminação. Ao se realizar uma IA somente com plasma seminal foi detectada uma grande infiltração de PMNs no estrato compacto do endométrio, porém a limpeza uterina foi superior quando o plasma seminal estava presente (TROEDSSON et al., 2008).

Outra aparente função do plasma seminal seria proteger 0 espermatozóide de ser fagocitado e destruído pelos PMNs. Quando as éguas são inseminadas duas vezes consecutivas no intervalo de 24 horas, a segunda IA é realizada em um ambiente inflamado que se torna deletério a motilidade dos espermatozóides. Dados sugerem que o plasma seminal protege seletivamente os espermatozóides viáveis, mas não os mortos, de se ligarem e serem fagocitados pelo PMNs (TROEDSSON et al., 2008).

O plasma seminal não contribui para a redução no processo inflamatório após IA, uma vez que um aumento no número de leucócitos no fluido uterino foi observado na sua presença, não podendo, desta forma, ser considerado um agente supressor (DELL'AQUA Jr. et al., 2006; TROEDSSON, 1999). Entretanto, Palm et al. (2006) e Card (2005) observaram uma menor reação inflamatória quando utilizou-se sêmen acrescido de plasma seminal, com uma 
diferença visível apenas 24 horas da IA. De acordo com Portus et al. (2005), a presença do plasma seminal na amostra inseminada, apesar de provocar maior reação inflamatória, leva a uma redução na duração do processo inflamatório e maior freqüência de contrações uterinas.

\section{Terapia aplicada a endometrite persistente pós-cobertura}

Para as éguas susceptíveis a EPPC, a terapia que visa minimizar o processo inflamatório é baseada em cuidados como diminuição do número de espermatozóides a ser inseminado bem como um menor número de inseminações por ciclo com intuito de reduzir a resposta inflamatória. Adicionalmente, uma rápida remoção dos fluidos inflamatórios acumulados no útero poucas horas após a cobertura ou IA se faz necessário. Essa remoção pode ser feito através de lavagem uterina visando à remoção de debris e/ou pela administração de drogas que estimulem a contração da musculatura uterina, sendo que ambos os procedimentos devem ser realizados entre 6 e 8 horas após IA (LEBLANC, 2003).

\subsection{Remoção mecânica}

Devido ao transporte espermático para o oviduto se completar dentro de 4 horas após a introdução do sêmen no corpo do útero, o lavado uterino deve ser realizado apenas após este período, evitando assim interferência no transporte espermático e consequente queda nas taxas de fertilidade. A lavagem do útero pode ser realizada com Ringer Lactato ou solução salina aquecidos com volume compatível a capacidade uterina (LEBLANC, 2003). Outro procedimento para favorecer a drenagem do conteúdo uterino é a dilatação manual da cérvix ou a administração local de PGE em éguas com dilatação cervical insuficiente por tornar o processo de retirada do fluido uterino mais eficiente (TROEDSSON et al., 2008). 


\subsection{Ocitocina parenteral}

No garanhão, fatores como aumento nas concentrações de ocitocina circulantes durante a atividade sexual e após a ejaculação e a presença de ocitocina nas glândulas sexuais acessórias e no sêmen indicam um importante papel das ocitocinas no transporte dos espermatozóides pelo trato reprodutivo da fêmea (WATSON et al, 1999).

Os receptores de ocitocina no endométrio e no oviduto das éguas, ovelhas e vacas estão presentes em maior número durante o fim do diestro e no estro. A administração de ocitocina exógena estimula a contração uterina e do oviduto das éguas, é possível que ela possa aumentar (por facilitar movimentos unidirecionais do útero para o oviduto) ou retardar (por evacuação do conteúdo uterino antes da colonização espermática do oviduto) o movimento do espermatozóide para o oviduto (GUTJAHR et al, 2000; RIGBY et al, 1999). O padrão de propagação e a intensidade das contrações são importantes fatores para promover o esvaziamento do conteúdo uterino, especialmente em éguas pluríparas onde o corpo do útero está localizado ventral à pelve (Reitzenstein et al, 2002).

A ocitocina tem duas formas de atuar no útero da égua, estimulando as contrações uterinas, atuando diretamente em receptores miometriais e liberando a PGF2 $\alpha$ do endométrio. Macrófagos, linfócitos e neutrófilos também têm potencial para liberar prostaglandinas e citocinas (interleucina I e fator de necrose tumoral) (CADARIO et al, 1999b). A utilização de PGF2a exógena, de 12 a 24 horas após a cobertura, induz contrações uterinas de menor intensidade quando comparadas com as contrações provocadas pela ocitocina (BRENDEMUEHL, 2002; LEBLANC, 2003).

A ocitocina, por ser um agente uterotônico, vem sendo utilizada rotineiramente no tratamento das éguas susceptíveis à EPPC, auxiliando na limpeza uterina (LEBLANC et al., 1994). A administração de ocitocina exógena, por estimular a contração uterina e do oviduto nas éguas pode também levar a um aumento no transporte espermático (RIGBY et al., 1999). Porém, o uso de ocitocina imediatamente ou 30 minutos após a IA não resulta em aumento na taxa de prenhês quando o número de espermatozóides é limitado. 
A eficácia do tratamento com ocitocina pode ser influenciada pela razão entre estrógeno e progesterona na hora de sua administração. A ocitocina atua na contração uterina por ligação com receptores miometriais, os quais variam em número durante o ciclo estral, sendo maior na fase estrogênica e menor no período pós-ovulatório, no momento em que a progesterona se encontra aumentada (RIGBY et al., 1999; GUTJAHR et al., 2000; VERONESI et al., 2006). Porém, Goddard \& Allen (1985) demonstraram que a ocitocina causa um rápido aumento na pressão intra-uterina de éguas por 20 minutos e sua atividade não foi consistentemente alterada pelo status reprodutivo do animal.

A ocitocina é o agente uterotônico de escolha para ajudar na limpeza uterina das éguas susceptíveis. Múltiplas doses de ocitocina, no dia da ovulação e no dia seguinte, não têm efeito no processo de formação do corpo lúteo e, portanto na produção de progesterona ou na taxa de prenhês (BRENDEMUEHL, 2002).

A completa limpeza uterina ocorre em 24 horas após o tratamento com ocitocina, o que confirma a eficácia dos hormônios ecbólicos exógenos no útero. Há uma maior sensibilidade do endométrio inflamado à ocitocina em éguas susceptíveis do que em éguas normais (CADARIO et al., 1999b; VERONESI et al., 2006).

A dose clínica de ocitocina mais usada é a de $20 \mathrm{UI}$, via intravenosa (IV) ou intramuscular (IM), podendo variar de 5 a $25 \mathrm{UI}$, sendo que as doses utilizadas dentro desse intervalo resultam no mesmo efeito, aumento nas contrações miometriais (MADILL et al., 2002). Quando existe a necessidade de tratamento com ocitocina após a ovulação, é recomendada a utilização da dose mais alta (25 UI) (GUTJAHR et al., 2000). Porém, Cadario et al. (1999a) relataram que altas doses de ocitocina ( $25 \mathrm{UI}$, IV) podem induzir uma contração tetânica em algumas éguas, resultando em retenção de fluido uterino.

\subsection{Ocitocina intra-uterina adicionada ao diluidor}

O uso de ocitocina parenteral em éguas que acumulam líquido intrauterino após a IA está estabelecido, porém relatos de seu uso intra-uterino são escassos. Uma dose de $30 \mathrm{UI}$ de ocitocina num tratamento intra-uterino 
demonstrou ter uma ação ecbólica maior comparado ao seu uso por via parenteral, aumentando o número de contrações nos cornos uterinos (CAMPBELL \& ENGLAND, 2002).

$A$ adição de ocitocina ao sêmen pode promover contrações uterinas e aumentar a fertilidade nas éguas que apresentam atraso na limpeza uterina. A adição de ocitocina ao sêmen não tem efeito na motilidade espermática de touros ou garanhões, o efeito principal da ocitocina no sêmen diluído não é sobre o espermatozóide, mas sim promovendo maior número de contrações uterinas, já que o útero inflamado das éguas susceptíveis possui maior sensibilidade à ocitocina (CLOUGH et al., 2006; CADARIO et al., 1999b).

Gallagher e Senger (1989) relataram que o uso de ocitocina adicionada ao diluidor de sêmen para congelação não afetou a porcentagem de acrossomos intactos ou a motilidade de espermatozóides bovinos.

\subsection{Prostaglandina parenteral}

Um importante papel da PGF2 $\alpha$ na limpeza física do útero é como promotor de contrações miometriais. A administração de ocitocina ou prostaglandina é comum no tratamento da EPPC buscando ajudar o útero a eliminar os fluidos inflamatórios (VERONESI et al, 2006).

Quando utilizada antes da ovulação, não se observa efeito sobre a formação do corpo lúteo ou na produção de progesterona. Em contrapartida, a administração da PGF2 a após a ovulação é capaz de interferir na formação luteal, resultando em diminuição da produção de progesterona e conseqüente redução da taxa de prenhez. Uma vantagem da PGF2a é a maior duração da atividade miometrial (5 horas) quando comparado com a ocitocina (45 minutos) (BRENDEMUEHL, 2002; LEBLANC, 2003).

Goddard \& Allen (1985) demonstraram que a PGF2a proporciona um aumento na pressão intra-uterina das éguas 10 minutos após sua administração declinando após 40 minutos e sua atividade não se altera pelo status reprodutivo do animal. 


\subsection{Prostaglandina intra-uterina adicionada ao diluidor}

A PGF2 $\alpha$ no sêmen tem se mostrando como indutora de contrações uterinas, facilitando o transporte espermático durante a fertilização no trato reprodutivo de suínos (Cheng et al., 2001; Cheng et al., 2006; HOVART \& BILKEI, 2003). a suplementação do sêmen diluído com PGF2a promove alterações benéficas na taxa de concepção e no retorno regular ao estro, entretanto, o tamanho da ninhada, o total de nascidos vivos e o intervalo entre desmama e parto não foram afetados (HOVART \& BILKEI, 2003; KOS \& BILKEI, 2004). Kozumplik e Martinek (1986) relataram que a PGF2 $\alpha$ não influencia as taxas de prenhês e o tamanho das crias em porcas, mas influencia negativamente a motilidade do espermatozóide suíno. A adição de pequenas quantidades de PGF2 $\alpha$ (125 e $250 \mu \mathrm{g}$ ) em sêmen diluído bovino que contém 100 milhões de espermatozóides $/ \mathrm{ml}$ é efetiva para aumentar a motilidade espermática (KARAHAN et al., 2006). Porém, a adição de PGF2 $\alpha$ ao diluidor de sêmen de cachaço nas concentrações de 2,5, 5 ou $10 \mathrm{mg}$ de PGF2 $\alpha$ por dose inseminante não aumenta a motilidade do espermatozóide (MAES et al, 2003).

A adição de estrógeno (11,5microg), PGF2a (5mg de lutalyse), ou ocitocina (4UI) ao sêmen suíno aumenta o número de fetos e o número de espermatozóides no segmento anterior do útero, fato este que pode ser considerado como decorrente de uma diminuição do refluxo espontâneo de sêmen e perda de espermatozóides após a IA. Portanto, em situações de baixa fertilidade, a adição desses componentes pode ser uma estratégia contra a infertilidade em suínos (WILLENBURG et al, 2003).

A concentração de PGF2 $\alpha$ exógena no diluidor de sêmen de cachaço não difere após 72 horas, o que indica que ela não é metabolizada durante esse período de tempo (Cheng et al., 2001; Cheng et al., 2006). Em eqüinos a concentração de PGF2a no sêmen diluído de garanhões após 24 horas de resfriamento permanece igual, essa estabilidade sugere que ela pode ser incorporada no momento do processamento do sêmen sem sofrer danos com o processo de resfriamento e pelo tempo de armazenagem (O'Bert et al., 2006). Dessa forma, a adição de PGF2a na dose de $125 \mu \mathrm{g} / \mathrm{ml}$ no sêmen diluído de eqüinos não promove alterações na motilidade espermática e mostra efeito 
benéfico na fertilidade, pois a PGF2 $\alpha$ atua no miométrio das éguas da mesma forma como atua nas outras espécies promovendo contração da musculatura uterina expulsando o fluido inflamatório e levando o espermatozóide até a junção útero tubária (PENROD et al., 2006).

A concentração média de PGF2a nos ejaculados de garanhões é de 260ng (CLAUS et al, 1992). O garanhão tratado com PGF2a (10mg, IM) uma hora antes da coleta de sêmen apresenta ejaculado com aumento do volume seminal livre de gel e diminuição na concentração espermática, já que o número de espermatozóides e a motilidade e não foram afetados (KREIDER et al. 1981).

\subsection{Antiinflamatórios não esteroidais sistêmicos}

Os antiinflamatórios não esteróides mostraram-se menos eficazes na minimização da reação inflamatória uterina após IA. A restrição do uso de antiinflamatórios não esteróides foi devido ao modo pelo qual este atua no processo inflamatório, inibindo somente a ação da enzima ciclooxigenase, desta forma limitando sua efetividade, já que o principal problema da EPPC é a intensa diapedese ocorrida no útero. De acordo com Leblanc (1997), a utilização de um antiinflamatório não esteróide como a fenilbutazona inibe a síntese de prostaglandinas (principalmente a PGF2 $\alpha$ ) atrasando a limpeza uterina das éguas, concordando com os achados de Reilas et al. (2006) os quais observaram que o flunixin meglumine aumenta a magnitude da reação inflamatória à presença do espermatozóide.

\subsection{Antiinflamatórios esteroidais sistêmicos}

Os AIES exercem sua função influenciando os eventos celulares, vasculares e o metabolismo de mediadores inflamatórios diminuindo a migração dos neutrófilos para o sítio de injúria, ao mesmo tempo em que estimula sua liberação pela medula óssea. A incapacidade de penetrar no local da lesão se deve a mudanças de conformação da superfície celular com 
estabilização da integridade microvascular via supressão das ações dos neutrófilos e pela inibição da síntese de mediadores inflamatórios e de agentes vasoativos ou trombogênicos, não permitindo a exsudação de fluidos (ANDRADE, 2002).

Levando o exposto em consideração, outra forma de tratamento recentemente proposta visa a imunomodulação da resposta inflamatória póscobertura através da utilização parenteral de antiinflamatórios esteróides. A administração sistêmica de antiinflamatórios esteróides (AIES) $(0,1 \mathrm{mg} / \mathrm{kg}$ de acetato de prednisolona) antes da IA levou a uma redução na função neutrofílica, diminuição do fluido uterino e contribuiu para uma limpeza mais adequada do útero. Neste mesmo experimento foi observada uma melhora significativa da fertilidade de éguas susceptíveis a EPPC. Contudo, o uso de AIES sistêmico deve ser feito com cautela por apresentar efeitos colaterais indesejáveis como imunossupressão e laminite (DELL'AQUA Jr. et al., 2006).

Outra proposta para prevenir a EPPC é o uso de dexametasona $(0,1 \mathrm{mg} / \mathrm{k})$. A administração em dose única dessa droga no momento da $I A$ reduz significativamente a turbidez do líquido intra-uterino acumulado após a IA nas éguas. O número de PMNs, que aumenta na presença do sêmen, não sofre alterações em sua contagem quando o tratamento com dexametasona é utilizado. Por sua vez, a quantidade de debris celulares independe se a égua foi tratada ou não. Não foi encontrada nenhuma relação entre o grau de fibrose estabelecido por biópsia (classificação de Kenney-Doig, 1986) e a turbidez do fluido, número de PMNs, desenvolvimento de edema endometrial e acúmulo de fluido uterino após a IA. Apesar de não apresentar diferença nos parâmetros acima citados a taxa de prenhes/ciclo aumentou significativamente quando 0 tratamento foi empregado nos animais que apresentavam uma coluna de fluido intra-uterino após a IA maior do que 2 centímetros combinado a sua persistência no útero por um período superior a 36 horas (BUCCA et al., 2008). 
Objetivos 


\section{OBJETIVOS}

O objetivo principal deste estudo foi verificar o efeito dos antiinflamatórios esteróides na reação inflamatória e na fertilidade de éguas resistentes e susceptíveis à endometrite persistente após a inseminação artificial.

Para constatação da influência da terapia com corticóide na imunomodulação da inflamação uterina foram avaliados:

- A influência da adição de anti-inflamatórios esteróides nas características do sêmen equino.

- O efeito da dexametasona na imunomodulação da reação inflamatória pós cobertura em éguas.

- Efeito da dexametasona na concentração de neutrófilos e óxido nítrico no fluído uterino de éguas. 
Trabalhos Científicos 


\title{
TRABALFO 1
}

\section{INFLUÊNCIA DA ADIÇÃO DE ANTI-INFLAMATÓRIOS ESTERÓIDES NAS CARACTERÍSTICAS DO SÊMEN EQUINO}

\author{
E.G. Fioratti, M.A. Alvarenga
}

\section{RESUMO}

Nas éguas, a endometrite persistente pós-cobertura, uma das causas mais freqüentes de infertilidade, é caracterizada por ser um processo inflamatório estimulado pelo contato dos espermatozóides com a mucosa uterina. Com a eficiência demonstrada pelas drogas antiinflamatórias esteróides na imunomodulação da inflamação e a possibilidade de utiliza-lás pela via intra uterina; o presente estudo objetivou avaliar a interação dos antiinflamatórios esteróides (AIES) adicionados ao diluidor de sêmen eqüino com a viabilidade espermática. Quinze AIES foram adicionados ao diluente seminal a base de leite desnatado (Botu-sêmen, Biotech, Botucatu) e o pH e osmolaridade foram mensurados. Vinte ejaculados de quatro garanhões de raças distintas $(n=20)$ foram coletados utilizando vagina artificial. Após avaliação da concentração e motilidade espermáticas, alíquotas com $800 \times 10^{6}$ de espermatozóides móveis cada foram diluídas em Botu-Semen ${ }^{\circledR}$ até 0 volume de $15 \mathrm{~mL}$. Posteriormente, uma alíquota foi novamente diluída com 15 $\mathrm{mL}$ de Botu-semen ${ }^{\circledR}$ (grupo controle) e as outras com $15 \mathrm{~mL}$ de Botu-semen ${ }^{\circledR}$ suplementado com um dos AIES (grupo tratado), resultando num volume final de $30 \mathrm{~mL}$ para ambos os grupos. As amostras foram incubadas em banho seco a $37^{\circ} \mathrm{C}$, apenas a dexametasona e a betametasona não provocaram queda acentuada da motilidade espermática nos primeiros 30 minutos de incubação. Pela potência anti-inflamatória e tempo de ação a dexametasona foi a droga de eleição para o estudo. Novas coletas de sêmen foram realizadas $(n=8)$ e as análises espermáticas foram realizadas para os grupos controle e suplementado com dexametasona nos instantes 0, 30, 60 e 120 minutos 
seguidos a diluição e após o período de 24 horas de refrigeração utilizando CASA e uma combinação de sondas fluorescentes para mensuração da integridade da membrana plasmática (lodeto de Propídeo) e acrossomal (FITCPSA) e potencial mitocondrial (JC-1). Não foi verificada diferença no $\mathrm{pH}$ e osmolaridade entre os meios suplementados com AIES. Comparando o grupo tratado e controle, os valores de motilidade progressiva e porcentagem de espermatozóides rápidos foram maiores no grupo controle $(p<0,05)$. $O$ grupo tratado mostrou menores valores $(p<0,05)$ para VAP em 30 e 60 minutos e integridade de membrana acrosomal em 60 minutos de incubação a $37^{\circ} \mathrm{C}$. Os resultados obtidos após 24 horas de refrigeração não mostraram diferença estatística entre os dois grupos $(p<0,05)$ para todas as análises realizadas, exceto para VAP, que foi menor $(p<0,05)$ para o grupo tratado. Com base nestes resultados, a dexametasona poderá ser adicionada ao sêmen de eqüinos no momento da inseminação ou antes da refrigeração por até 24 horas com o objetivo de minimizar a reação inflamatória advinda da presença dos espermatozóides no útero com mínima redução da qualidade espermática.

Palavras-chave: Sêmen refrigerado, dexametasona, endometrite persistente pós-cobertura

\section{INTRODUÇÃO}


A resposta uterina a presença de qualquer antígeno se traduz em uma reação inflamatória caracterizada pela liberação de mediadores quimiotáticos, presença de componentes da resposta imune celular e pela ativação do sistema complemento (Asbury et al., 1982, Watson et al., 1987, Troedsson et al., 1993a). O primeiro tipo celular a se deslocar atraído pelos fatores de quimiotaxia para o útero são os polimorfonucleares (PMNs), com intensa migração ocorrendo após a cobertura (Kotilainem et al., 1994; Troedsson, 1997; Katila, 1995), pois na fêmea equina, a deposição intra uterina do sêmen provoca uma reação inflamatória que é resultante do seu contato com o endométrio (Kotilainen et al., 1994, Troedsson et al., 1995).

A inflamação induzida pela cobertura é um processo fisiológico pelo qual o excesso de espermatozóides e possíveis contaminações bacterianas são eliminados do útero das éguas (Troedsson et al., 1998; Troedsson, 1999). No passado, se acreditava que a endometrite era exclusivamente resultante da contaminação bacteriana do útero e, dessa forma, as estratégias de tratamento permaneciam focadas na prevenção contra o acesso bacteriano ao interior do útero e administração de antibióticos. Mas com a evolução nas pesquisas foi constatado o fato de que algumas éguas possuem a capacidade de limpeza uterina comprometida e acabam por desenvolver uma endometrite persistente após a cobertura (EPPC) decorrente apenas da presença do espermatozóide no útero.

Essa resposta inflamatória transitória é um processo necessário à fertilidade, dessa forma, o tratamento das éguas normais não aumentará as taxas de fertilidade e pode ainda facilitar o estabelecimento de infecções por desbalancear a flora normal do trato reprodutivo (Troedsson et al., 2008). Atenção especial deve ser dada na identificação dessas éguas e no seu manejo reprodutivo para não agravar o quadro e favorecer possíveis infecções (Troedsson et al., 1995, Troedsson 1999, Troedsson et al., 2008).

A inseminação artificial (IA) com quantidade reduzida de espermatozóides e o uso de drogas ecbólicas associadas ao lavado uterino são os principais métodos de prevenção e de tratamento das éguas susceptíveis a EPPC. O sucesso do uso de antiinflamatórios esteroidais (AIES) na modulação da resposta inflamatória foi recentemente constatado por 
Dell'aqua et al. (2006) e Bucca et al. (2008), que observaram redução da intensidade da resposta inflamatória uterina ao espermatozóide e aumento na taxa de recuperação embrionária dessas éguas.

Uma vez que os AIES foram utilizados com sucesso para minimizar a resposta inflamatória no interior do útero, seu uso pela via intra uterina em dose reduzida pode controlar a reação inflamatória e aumentar as taxas de recuperação embrionária nas éguas susceptíveis a EPPC. Não foi encontrado na literatura informações referentes a interação dessas drogas com espermatozóides. Em função do exposto o presente estudo foi conduzido para verificar a influência da adição de vários AIES ao diluente de sêmen sobre a viabilidade espermática.

\section{MATERIAL E MÉTODOS}

2.1. EXPERIMENTO 1: efeito de diferentes AIES no $\mathrm{pH}$, osmolaridade e características espermáticas.

\subsubsection{Mensuração do pH e osmolaridade do diluidor de sêmen equino após adição de anti-inflamatórios esteróides.}

Quinze AIES foram adicionados ao diluente seminal a base de leite desnatado (Botu-sêmen, Biotech, Botucatu) nas quantidades demonstradas na tabela 1. De todas as amostras suplementadas o $\mathrm{pH}$ (pH-metro B374 Micronal) e osmolaridade (Osmette A - Precision System) foram mensurados. Os valores foram anotados e essas amostras foram descartadas, uma vez que não ocorre variações desses parâmetros decorrentes de partidas diferentes dos produtos utilizados.

\subsubsection{Colheita de sêmen e efeitos dos AIES nas características de motilidade espermática.}

Após verificação do $\mathrm{pH}$ e osmolaridade do extensor acrescido com AIES, foi realizada colheita de sêmen, com auxílio de uma vagina artificial modelo 
Botucatu, de cinco garanhões de diferentes raças e fertilidade conhecida, obtendo um total de 20 ejaculados (4 ejaculados/garanhão).

Imediatamente após a obtenção do sêmen e a retirada da fração gel por filtração foi realizada uma diluição desse na proporção de 1:1, sempre foi utilizado o mesmo diluidor para todas as amostras de sêmen coletadas. Após essa diluição prévia, a concentração foi mensurada com uso da câmara de Neubauer. Realizado esse processo foi separada uma dose contendo $800 \mathrm{x}$ $10^{6}$ de espermatozóides móveis. A motilidade espermática foi mensurada com uma gota de $10 \mu \mathrm{L}$ de sêmen diluído colocada em câmara de Makler pré aquecida (10 $\mu \mathrm{m}$ de profundidade) a $38^{\circ} \mathrm{C}$ e avaliada por análise computadorizada (CASA, HTM - IVOS 12; Hamilton Thorne Research, Beverly, $M A)$ no modo ajustado para eqüinos.

\subsubsection{Processamento das amostras seminais}

Cinco alíquotas iguais contendo $800 \times 10^{6}$ de espermatozóides móveis foram diluídas em diluidor comercial a base de leite até alcançar o volume de $15 \mathrm{~mL}$. Uma alíquota foi re-diluída com $15 \mathrm{~mL}$ do mesmo diluidor e as outras quatro amostras com $15 \mathrm{~mL}$ desse extensor suplementado com algum dos AIES que estão apresentados na tabela 1 de forma aleatória, alcançando, dessa forma, um volume final de $30 \mathrm{~mL}$. Essas cinco amostras foram então incubadas em um "dry block" a uma temperatura de $37^{\circ} \mathrm{C}$ por 2 horas. As análises das características espermáticas foram realizadas nos momentos da diluição (momento zero), 30, 60 e 120 minutos após a diluição.

Esse primeiro experimento foi responsável pela identificação de quais AIES seriam possíveis de serem adicionados ao diluidor de sêmen com mínima interferência nas características da motilidade dos espermatozóides. Uma vez feita a seleção, estudos mais aprofundados foram realizados para mensurar a interação entre essa droga e os espermatozóides. Devido aos resultados obtidos no presente experimento a dexametasona foi escolhida para ser adicionada ao diluidor seminal.

2.2 EXPERIMENTO 2: efeito da adição da dexametasona nas caracteríticas de motilidade e integridade espermática. 


\subsubsection{Colheita de sêmen e análise da motilidade espermática}

Quatro garanhões de diferentes raças e fertilidade conhecida tiveram o sêmen coletado duas vezes por vagina artificial modelo Botucatu, obtendo um total de 8 ejaculados. Imediatamente após a obtenção do sêmen e a retirada da fração gel por filtração foi realizada uma diluição na proporção de 1:1 sempre com o mesmo diluidor. A motilidade espermática foi medida com uma gota de $10 \mu \mathrm{L}$ de sêmen diluído colocada em uma câmara de Makler pré aquecida (10 $\mu \mathrm{m}$ de profundidade) a uma temperatura de $38^{\circ} \mathrm{C}$ e avaliada pelo CASA no modo ajustado para eqüino e a concentração foi mensurada em câmera de Neubauer.

\subsubsection{Processamento das amostras seminais}

Após analisar a motilidade e concentração espermática, duas alíquotas contendo $800 \times 10^{6}$ de espermatozóides móveis foram diluídas até alcançarem um volume de $15 \mathrm{~mL}$. Cada amostra foi re-diluída até um volume final de 30 $\mathrm{mL}$, uma com diluidor não suplementado e a segunda com diluidor suplementado com $2 \mathrm{mg}$ de dexametasona, o que garantiu uma concentração de $0,067 \mathrm{mg} / \mathrm{mL}$. Ambas as amostras foram divididas em duas partes iguais, a primeira metade foi refrigerada a $5^{\circ} \mathrm{C}$ por 24 horas em caixa de transporte de sêmen eqüino e a outra parte foi incubada em um "dry block" em temperatura de $37^{\circ} \mathrm{C}$ durante 2 horas. As análises dos parâmetros espermáticos foram realizadas nos momentos $0,30,60$ e 120 minutos após a diluição e após 24 horas de refrigeração usando CASA.

\subsubsection{Análise das características morfológicas e funcionais dos espermatozóides.}

As análises morfofuncionais dos espermatozóides foram realizadas nos momentos 0, 30, 60 e 120 minutos após a diluição e após 24 horas de refrigeração utilizando uma combinação de sondas fluorescentes para se 
mensurar a integridade das membranas plasmática e acrossomal e o potencial da membrana mitocondrial.

O protocolo para avaliação simultânea da integridade das membranas plasmática e acrossomal e do potencial da membrana mitocondrial foi adaptado de Celeghini et al (2004). Dessa forma, para essas avaliações foram utilizados $20 \mu \mathrm{L}$ de sêmen que foram adicionados a uma solução feita previamente contendo as 3 sondas fluorescentes; lodeto de propídeo $(0,8 \mu \mathrm{L}, 28,707-5$; Sigma), FITC-PSA (20 $\mu \mathrm{L}$, L-0770, Sigma) e JC-1 (2,5 $\mu \mathrm{L}$, T3168, Molecular Probes). Para cada amostra, 200 células foram contadas usando um microscópio de epifluorescência (NIKON, Episcopic Fluorescence Attachment "EFA" HalogenLamp Set).

\subsection{Análise estatística}

Para todas as análises das características de motilidade espermática e da morfuncionalidade dos espermatozóides foram realizados os testes ANOVA e Tukey com nível de significância de $5 \%(p<0,05)$. Os dados foram expressos como média \pm desvio padrão.

\section{RESULTADOS}

\subsection{Experimento 1}

Os resultados referentes à dose, ao $\mathrm{pH}$ e a osmolaridade dos AIES utilizados no presente trabalho foram apresentados na tabela $1 . \mathrm{O} \mathrm{pH} \mathrm{e} \mathrm{a}$ osmolaridade do diluidor utilizado para todas as amostras seminais avaliadas (Botu-sêmen) foram mensurados em 6,77 e $368 \mathrm{mOsm}$, respectivamente. $\mathrm{O}$ produto comercial não apresenta variação significativa dos parâmetros acima citados capazes de interferir nas mensurações realizadas ou na qualidade das amostras seminais. 
Tabela 1. Valores de dose, $\mathrm{pH}$ e osmolaridade mensurados no diluidor de sêmen equino após adição de 15 anti-inflamatórios esteróides.

\begin{tabular}{|c|c|c|c|}
\hline DROGAS & Dose $^{*}$ & $\mathrm{pH}$ & Osmolaridade ${ }^{\star *}$ \\
\hline Succinato sódico de hidrocortisona & 100 & 6,95 & 380 \\
\hline Succinato de hidrocortisona & 100 & 6,88 & 384 \\
\hline Fosfato dissódico de betametasona & 1 & 6,73 & 374 \\
\hline Acetato de betametasona & 1 & 6,63 & 354 \\
\hline Dipropionato de betametasona & 1 & 6,77 & 382 \\
\hline Fosfato de betametasona & 1 & 6,7 & 364 \\
\hline Acetato e fosfato dissódico de betametasona & 1 & 6,76 & 356 \\
\hline Dipropionato e fosfato dissódico de betametasona & 1 & 6,87 & 381 \\
\hline Dipropionato e fosfato de Betametasona & 1 & 6,77 & 364 \\
\hline Dexametasona & 2 & 6,87 & 351 \\
\hline Triancinolona acetonida & 20 & 6,71 & 380 \\
\hline Fosfato dissódico de prednisolona & 40 & 6,81 & 392 \\
\hline Acetato de 9-alpha-prednisolona & 40 & 6,77 & 384 \\
\hline Acetato de metilprednisolona & 40 & 6,83 & 387 \\
\hline Succinato sódico de metilprednisolona & 40 & 6,71 & 379 \\
\hline
\end{tabular}

Entre as 15 variações de AIES testadas no presente estudo, 13 dessas drogas provocaram injúrias que resultaram em pronunciada perda de motilidade espermática dentro de 30 minutos de incubação após a diluição. Apenas duas drogas que durante os 120 minutos de incubação não exibiram diferenças quando comparadas ao grupo controle, exceto por uma pequena diminuição nos valores das velocidades dos espermatozóides (tabela 2 e 3). As 
amostras suplementadas com a associação dos sais dipropionato e fosfato de Betametasona $(0,13 \mathrm{mg} / \mathrm{mL})$ e com a dexametasona $(0,067 \mathrm{mg} / \mathrm{mL})$ foram aquelas que mantiveram valores similares das características de motilidade espermática ao grupo controle.

Como a betametasona selecionada possui uma apresentação composta pelos sais dipropionato e fosfato, que têm por característica uma combinação de um sal de baixa e um sal de alta solubilidade, e por conseqüência, uma ação curta e uma longa, se optou por excluir esse possível tratamento, assim sendo, a dexametasona foi escolhida por se apresentar de forma mais pura e também por sua potência e tempo de ação.

Tabela 2. Valores médios e desvios padrão das características de movimento espermático nos momentos 0 e 30 minutos após a diluição das amostras de sêmen equino com diluidor contendo coticóide e grupo controle $(n=20)$.

\begin{tabular}{|c|c|c|c|c|c|c|}
\hline & \multicolumn{3}{|c|}{0} & \multicolumn{3}{|c|}{$30 \mathrm{~min}$} \\
\hline & C & DF & D & C & DF & D \\
\hline TM & $75,7 \pm 8,8^{a}$ & $66,0 \pm 12,7^{\mathrm{a}}$ & $69,2 \pm 8,1^{\mathrm{a}}$ & $76,5 \pm 8,3^{\mathrm{a}}$ & $67,2 \pm 9,2^{\mathrm{a}}$ & $61,0 \pm 13,5^{\mathrm{a}}$ \\
\hline PM & $36,0 \pm 3,4^{\mathrm{a}}$ & $30,7 \pm 9,0^{\mathrm{a}}$ & $33,2 \pm 8,4^{\mathrm{a}}$ & $40,0 \pm 13,4^{\mathrm{a}}$ & $41,5 \pm 13,0^{a}$ & $30,5 \pm 17,7^{\mathrm{a}}$ \\
\hline VAP & $133,7 \pm 7,3^{\mathrm{a}}$ & $119,2 \pm 7,6^{b}$ & $114,0 \pm 9,8^{b}$ & $124,5 \pm 9,5^{a}$ & $105,5 \pm 7,5^{b}$ & $72,2 \pm 12,9^{b}$ \\
\hline VSL & $99,2 \pm 9,5^{a}$ & $89,5 \pm 6,3^{b}$ & $88,5 \pm 10,5^{b}$ & $97,5 \pm 12,5^{\mathrm{a}}$ & $84,7 \pm 11,9^{b}$ & $77,7 \pm 10,4^{b}$ \\
\hline VCL & $244,2 \pm 8,3^{\mathrm{a}}$ & $230,0 \pm 17,2^{\mathrm{b}}$ & $222,2 \pm 5,9^{b}$ & $225,2 \pm 9,3^{\mathrm{a}}$ & $215,7 \pm 12,7^{b}$ & $191,0 \pm 15,1^{b}$ \\
\hline \multicolumn{7}{|c|}{$\begin{array}{l}\text { Média } \pm \text { desvio padrão. Letras diferentes na mesma linha indicam diferença estatística entre os } \\
\text { grupos no mesmo momento }(\mathrm{P}<0.05) \text {. C (grupo controle); DF (dipropionato e fosfato de } \\
\text { betametasona); D (dexametasona); TM (motilidade total); PM (motilidade progressiva); VAP } \\
\text { (velocidade ao longo de uma trajetória média); VSL (velocidade ao longo de uma linha reta); } \\
\text { VCL (velocidade ao longo de uma trajetória real). }\end{array}$} \\
\hline
\end{tabular}


Tabela 3. Valores médios e desvios padrão das características de movimento espermático nos momentos 60 e 120 minutos após a diluição das amostras de sêmen equino com diluidor contendo corticóide e grupo controle $(n=20)$.

\begin{tabular}{|c|c|c|c|c|c|c|}
\hline & \multicolumn{3}{|c|}{$60 \mathrm{~min}$} & \multicolumn{3}{|c|}{$120 \mathrm{~min}$} \\
\hline & C & DF & D & C & DF & D \\
\hline TM & $72,5 \pm 6,1^{\mathrm{a}}$ & $64,5 \pm 15,7^{\mathrm{a}}$ & $59,0 \pm 12,0^{\mathrm{a}}$ & $63,7 \pm 11,7^{\mathrm{a}}$ & $46,7 \pm 11,7^{\mathrm{a}}$ & $42,0 \pm 20,1^{\mathrm{a}}$ \\
\hline PM & $41,7 \pm 12,5^{\mathrm{a}}$ & $40,0 \pm 19,5^{\mathrm{a}}$ & $29,7 \pm 9,0^{\mathrm{a}}$ & $32,0 \pm 14,3^{\mathrm{a}}$ & $22,0 \pm 11,0^{\mathrm{a}}$ & $17,2 \pm 14,2^{\mathrm{a}}$ \\
\hline VAP & $112,5 \pm 8,5^{a}$ & $105,5 \pm 9,1^{b}$ & $96,25 \pm 4,5^{\mathrm{b}}$ & $90,0 \pm 8,4^{\mathrm{a}}$ & $77,7 \pm 5,6^{b}$ & $75,0 \pm 8,1^{b}$ \\
\hline VSL & $90,7 \pm 7,6^{\mathrm{a}}$ & $77,7 \pm 7,6^{\mathrm{b}}$ & $77,0 \pm 3,4^{b}$ & $74,7 \pm 7,1^{\mathrm{a}}$ & $69,5 \pm 10,7^{b}$ & $63,5 \pm 10,3^{b}$ \\
\hline VCL & $209,2 \pm 11,3^{\mathrm{a}}$ & $199,0 \pm 16,1^{b}$ & $193,7 \pm 11,8^{b}$ & $172,7 \pm 15,1^{\mathrm{a}}$ & $182,0 \pm 12,7^{b}$ & $157,5 \pm 6,9^{b}$ \\
\hline \multicolumn{7}{|c|}{$\begin{array}{l}\text { Média } \pm \text { desvio padrão. Letras diferentes na mesma linha indicam diferença estatística entre os } \\
\text { grupos no mesmo momento ( } \mathrm{P}<0.05) \text {. C (grupo controle); DF (dipropionato e fosfato de } \\
\text { betametasona); D (dexametasona); TM (motilidade total); PM (motilidade progressiva); VAP } \\
\text { (velocidade ao longo de uma trajetória média); VSL (velocidade ao longo de uma linha reta); } \\
\text { VCL (velocidade ao longo de uma trajetória real). }\end{array}$} \\
\hline
\end{tabular}

\subsection{Experimento 2}

Ao se comparar o grupo controle com o grupo tratado com dexametasona, em todos os momentos de incubação, não foi verificada diferença estatística significativa $(p<0,05)$ para os parâmetros motilidade total, integridade de membrana plasmática e potencial de membrana mitocondrial. Porém, os valores encontrados para motilidade progressiva e a porcentagem de espermatozóides rápidos foram maiores $(p<0,05)$ no grupo controle do que no tratado (tabela 4). $O$ grupo tratado mostrou menores $(p<0,05)$ valores para VAP após $30(72,25 \pm 42,91$ vs $124,5 \pm 13,5)$ e 60 minutos $(96,25 \pm 4,5$ vs 
$112,5 \pm 8,50)$, maiores $(p<0,05)$ valores para porcentagem de espermatozóides com a membrana acrossomal íntegra no momento 0 ( $72 \pm 3,24 \%$ vs $56 \pm 4,09 \%)$ e menores valores $(p<0,05)$ após 60 minutos $(28 \pm 2,97 \%$ vs $48 \pm 3,46 \%)$ de incubação quando comparado ao grupo controle. Os resultados obtidos após 24 horas de refrigeração não demonstraram diferença $(p<0,05)$ entre os grupos para todos os parâmetros mencionados acima, exceto para VAP, o qual se apresentou inferior $(p<0,05)$ no grupo tratado $(77,38 \pm 19,65$ vs $106,75 \pm 28,06)$ em comparação ao grupo controle.

Tabela 4. Valores médios e desvios padrão para motilidade progressiva e porcentagem de espermatozóides rápidos nos momentos $0,30,60$ e 120 minutos após a diluição das amostras de sêmen equino em diluente controle e adicionado com dexametasona $(n=8)$.

\begin{tabular}{|c|c|c|c|c|c|c|c|c|}
\hline \multirow{2}{*}{$\begin{array}{l}\text { Tempo } \\
\text { AIES }\end{array}$} & \multicolumn{2}{|c|}{ Após diluição } & \multicolumn{2}{|c|}{$30 \mathrm{~min}}$. & \multicolumn{2}{|c|}{$60 \mathrm{~min}}$. & \multicolumn{2}{|c|}{$120 \mathrm{~min}}$. \\
\hline & PM & RAP & PM & RAP & PM & RAP & PM & RAP \\
\hline C & $32,2 \pm 3,6^{a}$ & $59,4 \pm 3,2^{\mathrm{a}}$ & $34,4 \pm 2,8^{\mathrm{a}}$ & $58,0 \pm 4,4^{a}$ & $33,6 \pm 6,3^{\mathrm{a}}$ & $50,8 \pm 6,5^{\mathrm{a}}$ & $25,6 \pm 3,3^{\mathrm{a}}$ & $34,2 \pm 6,1^{a}$ \\
\hline D & $27,4 \pm 4,6^{b}$ & $45,0 \pm 2,4^{b}$ & $24,4 \pm 2,0^{b}$ & $38,0 \pm 4,8^{b}$ & $23,8 \pm 3,7^{b}$ & $37,0 \pm 5,4^{b}$ & $13,8 \pm 4,6^{b}$ & $28,2 \pm 7,3^{b}$ \\
\hline
\end{tabular}

\section{DISCUSSÃO}

De acordo com Makler et al. (1981) a acidez no ambiente uterino pode ser responsabilizada pela imobilização dos espermatozóides, mas com sua correção a motilidade espermática retorna ao normal, porém, em uma condição alcalina, a perda de motilidade se apresenta de forma irreversível. Além disso, a hiposmolaridade é mais deletéria a motilidade espermática de humanos do 
que a hiperosmolaridade, e qualquer redução da motilidade está relacionada com alterações osmóticas que são consideradas irreversíveis. Segundo Crinch e Jequier (1978) o pH uterino pode afetar a motilidade espermática, mas mudanças na osmolaridade são muito mais prejudiciais levando a imobilidade total das células.

Estudos anteriores relataram que os valores de osmolaridade e $\mathrm{pH}$ do sêmen de garanhões varia entre 280 a $300 \mathrm{mOsm} / \mathrm{kg}$ e 7,4 a 7,6, respectivamente (Macedo et al., 2003) e que as amostras espermáticas obtidas de diferentes garanhões ao longo de 12 meses não apresentaram variação desses parâmetros, pois o valor médio obtido para a osmolaridade foi de 292,9 $\mathrm{mOsm} / \mathrm{kg}$ e para o $\mathrm{pH}$ foi de 7,37 (Zahn et al., 2001).

O espermatozóide equino apresenta baixa tolerância às variações de osmolaridade (Ball e Vo, 2001), e por essa razão, o diluidor para o sêmen deve apresentar uma pressão osmótica compatível a apresentada pelo ejaculado e o valor do $\mathrm{pH}$ deve ficar ao redor da neutralidade. Para os diluidores de sêmen equino é desejável que a osmolaridade permaneça entre 250 e $400 \mathrm{mOsm} / \mathrm{kg}$ para sua melhor utilização (Katila, 1997), uma vez que as variações na osmolaridade podem levar a perda acentuada das características de motilidade da célula espermática (Ball e Vo, 2001).

Com conhecimento dessa interferência na qualidade seminal foi realizada uma triagem e os valores obtidos para o extensor utilizado no estudo foram os seguintes, 6,77 para o $\mathrm{pH}$ e $368 \mathrm{mOsm} / \mathrm{kg}$ para a osmolaridade. A partir da definição dos valores do $\mathrm{pH}$ e da osmolaridade para o meio base, foram realizadas as suplementações com diversos AIES e mensuradas as variações nesses dois parâmetros, assim sendo, o pH dos diversos meios extensores variou entre 6,63 a 6,95 e, a osmolaridade permaneceu entre 351 e $392 \mathrm{mOsm} / \mathrm{Kg}$. Os resultados obtidos após a suplementação não demonstraram variações além daquelas estabelecidas como fisiológicas por Macedo et al. (2003) e por Zahn et al (2001) e a suplementação com AIES manteve a osmolaridade do diluuidor seminal no intervalo de interesse estabelecido por Katila (1997).

Considerando os resultados acima apresentados, a marcante redução na motilidade espermática observada após a adição dos AIES, com exceção da dexametasona e de uma associação entre sais de betametasona, não pode ser 
atribuída as variações nos valores no $\mathrm{pH}$ e osmolaridade do diluidor de sêmen.

A diminuição na motilidade espermática pode ter sido resultado de alterações nas propriedades físico-químicas do diluidor após adição dos AIES causadas por algum tipo de interação entre os componentes do diluente e os sais que compõem a formulação desses. Além disso, uma vez que os corticóides utilizados tem diferenças na hidrosolubilidade, interações deles com a membrana do espermatozóide e sua consequente penetração no interior celular pode ter induzido a modificações estruturais e funcionais, no metabolismo espermático e nas interações que ocorrem entre os espermatozóides e o meio diluidor que resultaram em diminuição da motilidade.

A motilidade é considerada um dos fatores mais importantes associados com a capacidade de fertilização do espermatozóide, pois a expressão dessa característica está diretamente relacionada à viabilidade e integridade estrutural da célula espermática (Verstegen et al., 2002). Outra prova de sua importância é que as taxas de fertilização "in vitro" de oócitos de várias espécies animais têm se mostrado positivamente correlacionadas com a motilidade espermática (Amman, 1989).

Mediante a importância das características do movimento espermático, a sua avaliação pelo CASA oferece maior confiabilidade e repetibilidade na mensuração dos diversos parâmetros espermáticos e ainda mensurações impossíveis de serem realizadas com a análise subjetiva. Esse conjunto de fatores permite uma determinação objetiva de todos os parâmetros relacionados ao movimento dos espermatozóides (Amann \& Katz, 2004). Um bom exemplo da importância da análise computadorizada é a descoberta que em espermatozóides humanos, por exemplo, é possível fazer a distinção entre os inférteis e os férteis baseado na mensuração da velocidade espermática (Milligan et al., 1980). Em touros, a motilidade e velocidade quando combinadas demonstraram estar altamente correlacionadas com fertilidade (Farrel et al., 1998). Uma correlação positiva entre o número total de espermatozóides móveis inseminados, $\mathrm{VCL}$ e fecundidade foram observados (Gerris e Khan, 1987; Byrd et al., 1990), uma vez que os valores de VCL estão fortemente correlacionados com as taxas de fertilização "in vitro" (Holt at al., 1994). 
De acordo com os resultados obtidos no presente experimento, foi constatada uma diminuição nos valores referentes a velocidade espermática (VCL, VSL e VAP) quando comparados ao grupo controle, dessa forma, este fato pode interferir nas taxas de fertilidade conforme citado acima. A capacidade fertilizante dos espermatozóides relacionada as características do movimento não sofreu influência da suplementação com AIES, pois o movimento característico da hiperativação que é indicado por um significativo aumento da VCL e ALH e uma diminuição no STR (Verstegen et al., 2002) não foi observado nos espermatozóides após incubação ou refrigeração em diluidor adicionado com dexametasona.

Entretanto, a capacidade fertilizante do espermatozóide também está vinculada com sua integridade física e funcional. A integridade da membrana plasmática é fator de extrema necessidade para a sobrevivência do espermatozóide no trato reprodutivo feminino e para manutenção de sua capacidade fertilizante (Parks \& Graham, 1992).

A relação entre a avaliação in vitro de espermatozóides e a fertilidade in vivo dos garanhões permanece obscura, apesar de diversos métodos terem sido desenvolvidos para avaliar a viabilidade ou o estado acrossomal de espermatozóides em preparações coradas. A integridade da membrana plasmática pode ser considerada um indicador indireto da viabilidade espermática (Magistrini et al., 1997).

É possível avaliar a integridade da membrana plasmática dos espermatozóides com 0 uso do iodeto de propídeo, pois as células espermáticas que apresentarem danos a integridade da membrana celular permitem a passagem do corante através dela e sua ligação com o DNA nuclear emitindo fluorescência (Garner et al., 1986, Garner et al., 1988, Harrison and Vickers, 1990, Maxwell et al., 1997).

O contato direto entre a membrana dos espermatozóides e a dexametasona poderia provocar uma marcante estabilização dessa membrana plasmática impedindo, dessa forma, as modificações necessárias para a capacidade fertilizante. Porém, a habilidade de estabilizar membranas, e com isso imperdir a liberação de mediadores químicos pró inflamatórios, só pode ser observada em exposição a doses supra-farmacológicas de AIES, não se reproduzindo em doses terapêuticas convencionais. Dessa forma, dados 
obtidos nesse experimento demonstraram que a integridade da membrana espermática não foi alterada pelo contato com a dexametasona.

A avaliação do estado acrossomal pode ser utilizada para monitorar o dano após o congelamento, já que este processo pode afetar a incidência de acrossomos intactos (Cross e Hanks, 1991), mas também pode ser utilizado para acompanhar as lesões causadas pela incubação e ainda verificar a ocorrência da reação acrossomal, pois o acrossomo do espermatozóide deve permanecer intacto durante o carreamento desse pelo útero até o sítio de fertilização, pois a perda do acrossomo ou uma reação acrossomal espontânea os torna incapazes de exercer sua função de fertilização por não conseguirem se ligar a zona pelúcida e fertilizar o oócito (Silva \& Gadella, 2006). No espermatozóide equino o PSA se liga a matriz glicoprotéica do acrossomo (Cheng et al., 1998, Flesch et al., 1998). Uma vez que o PSA não consegue penetrar na membrana acrossomal intacta ele só pode corar aqueles espermatozóides que apresentarem o acrossomo reagido ou danificado.

No presente experimento foi utilizada a associação FITC-PSA para verificar a integridade da membrana acrossomal e determinar se a suplementação com AIES seria capaz de induzir alguma modificação estrutural nela. Assim como na membrana plasmática, os resultados obtidos para a mensuração da integridade da membrana acrossomal demonstram que as interações com a dexametasona não produzem danos ao acrossomo.

Como citado anteriormente, as característica do movimento espermático são fundamentais para a fertilização, mas esse movimento está intimamente ligado ao funcionamento das mitocôndrias, uma vez que a porcentagem de mitocôndrias que se apresentam com funcionalidade normal está altamente correlacionada com a porcentagem de espermatozóides móveis e viáveis (Garner et al., 1997; Thomas et al., 1998). Em garanhões, uma relação entre função mitocondrial, motilidade e as características das velocidades têm sido observada (Papaioannou et al., 1997; Love et al., 2003).

Foi verificado em citometria de fluxo usando as sondas fluorescentes SYBR-14, iodeto de propídeo e JC-1 que o potencial de membrana mitocondrial está correlacionado com os parâmetros espermáticos ALH, STR e LIN (Love et al., 2003). A funcionalidade e integridade da mitocôndria parecem ser importantes para a sobrevivência do espermatozóide no trato genital 
feminino. Assim sendo, o JC-1 pode ser usado para verificar a despolarização da membrana mitocondrial interna e reportar a funcionalidade mitocondrial (Silva and Gadella, 2006). O JC-1 permite a indentificação dos espermatozóides em graus variados de funcionalidade mitocondrial, ele é internalizado por todas mitocôndrias funcionais e naquelas que apresentam funcionalidade, a alta concentração de JC-1 forma agregados que fluorescem na cor laranja. Dessa forma, se torna possível uma classificação de subpopulações de espermatozóides com alto, moderado e baixo potencial de membrana mitocondrial por microscopia de fluorescência.

Nesse estrabalho foi considerada como ativada qualquer amostra que respondeu ao estímulo, não fazendo diferenciação entre as intensidades de resposta ou uma classificação dos espermatozóides baseada nesse parâmetro.

A associação entre as sondas fluorescentes permitiu a avaliação simultânea das células espermáticas para os parâmetros de integridade de membrana plasmática e acrossomal e potencial de membrana mitocondrial. No presente estudo não foi verificada diferença significativa entre o grupo tratado com dexametasona e o controle. Dessa forma, a integridade estrutural e funcional dos espermatozóides foi mantida indicando que sua capacidade fertilizante sob esse aspecto permanece intacta.

Assim como o tratamento com antiinflamatórios intra articulares visa maior segurança em minimizar os efeitos sistêmicos das drogas utilizadas, sua utilização pela via intra uterina pode propiciar uma alternativa para seu uso em dose reduzida e aplicação única. Mas, uma vez que a utilização de antibióticos intra uterinos permitem maior resistência bacteriana, irritação do endométrio e podem interferir com o mecanismo de defesa uterino por reduzir a atividade fagocítica dos neutrófilos (Davis et al., 1987), para apresentar efetividade na imunomodulação da resposta inflamatória no útero após a cobertura o tratamento local com dexametasona deve ser melhor explorado.

A partir das informações obtidas no presente trabalho foi constatado que a integridade, funcionalidade, viabilidade e longevidade dos espermatozóides durante o período de incubação e refrigeração foram similares a daqueles que não tiveram contato com o diluidor que passou por adição de dexametasona. Dessa forma, estudos futuros são necessários para constatar o efeito da adição de AIES no diluidor sobre a fertilidade e o controle da inflamação uterina após 
cobertura, pois a concentração de dexametasona foi ajustada para provocar menor prejuízo as características seminais, o que pode não garantir sua eficácia na prevenção dos efeitos inflamatórios provocados pelo contato do sêmen com o útero.

\section{REFERÊNCIAS BIBLIOGRÁFICAS}

Alghamdi, A., Troedsson, M.H.T., Lasckewitsch, T., Xue, J.L. 2001. Uterine secretion from mares with post-breeding endometritis alters sperm motion characteristics in vitro. Theriogenology. 55, 1019-1028.

Amann, R.P. 1989. Can the fertility potential of seminal sample be predicted accurately? J. Androl. 10, 89-98.

Amann, R.P.; Katz, D.F. 2004. Reflections on CASA after 25 years. J. Androl. 25, 317.

Asbury, A.C., Halliwell, R.E., Foster, G.W., Longino, S.J. 1980. Immunoglobulins in uterine secretions of mares with differing resistance to endometritis. Theriogenology. 14, 299-308.

Asbury, A.C.; Schultz, K.T.; Klesius, P.H.; Foster, G.N.; Washburn, S.M. 1982. Factors affecting phagocytosis of bacteria and neutrophils in the mare uterus. J. Reprod. Fert. Suppl. 32, 151-159.

Asbury, A.C.; Lyle, S.K.. 1993. Infectious causes of infertility. In: McKinnon, A.O.; Voss, J.L. (ED). Equine reproduction. Philadelphia: Lea \& Febiger, pp. 381-391.

Bader H. 1982. An investigation of sperm migration into the oviducts of the mare. J. Reprod. Fert. (Suppl). 32, 59-64. 
Ball, B.A., Vo; A. 2001. Osmotic tolerance of equine spermatozoa and the effects of soluble cryoprotectants on equine sperm motility, viability, and mitochondrial membrane potential. J. Androl. 22, 1061-1069.

Brinsko, S.P.; Varner, D.D.; Blanchard, T.L. 1991. The effect of uterine lavage performed four hours post-insemination on pregnancy rates in mares. Theriogenology. 35, 1111-1191.

Bucca, S.; Carli, A.; Buckley; T.; Dolci, G., Fogarty, U. 2008. The use of dexamethasone administered to mares at breeding time in the modulation of persistent mating induced endometritis. Theriogenology. 70, 1093-1100.

Byrd, W., Bradshaw, K. Carr, B., Edman, C., Odom, J., Ackerman, G. 1990. A prospective randomized study of pregnancy rates following intrauterine and intracervical insemination using frozen donor semen. Fertil. Steril. 53, 521-527.

Celeghini, E.C.C., Arruda, R.P., Andrade, A.F.C., Raphael, C.F., Nascimento, J. 2004. Simultaneous evaluation of the plasma, acrosomal and mitochondrial membranes in equine spermatozoa. Proceedings of the 15th International Congress Animal Reproduction. 15, 511.

Cheng, F.P., Gadella, B.M., Voorhout, W.F., Fazeli, A., Bevers, M.M., Colenbrander, B. 1998. Progesterone-induced acrosome reaction in stallion spermatozoa is mediated by a plasma membrane progesterone receptor. Biol Reprod. 59, 733-42.

Crinch, J.P.; Jequier, A.M. 1978. Infertility in man with retrograde ejaculation: the action of purine on sperm motility, and a simple method for achieving antegrade ejaculation. Fertil. Steril. 30, 572-576.

Cross, N.L.; Hanks, S.E. 1991. Effects of cryopreservation on human sperm acrosomes. Human Reprod. 6, 1279-1283. 
Dell'Aqua Jr., J.A.; Papa, F.O.; Lopes, M.D., Alvarenga, M.A.; Macedo, L.P.; Neves Neto, J.R.; Melo, C.M.; Duarte, M.P.; Duarte, M.C.G. 2004. Fertility rates with equine frozen semen after modulation of inflammatory uterine response. Proceedings of the 15th International Congress Animal Reproduction. 391.

Davis, J.L.; Lock, T.F.; Dipietro, J.A. 1987. The effect of antibiotics on metabolic activity of equine neutrophils. Proceedings of the Annual Meeting of the Society for Theriogenology. 363.

Dell'Aqua Jr., J.A.; Papa, F.O.; Lopes, M.D., Alvarenga, M.A.; Macedo, L.P.; Melo, C.M. 2006. Modulation of acute uterine inflamatory response after artificial insemination with equine frozen semen. Anim. Reprod. Sci. 94, 270273.

Farrel, P.B. Presicce, G.A., Brockett, C.C., Foote, R.H. 1998. Quantification of Bull sperm characteristics measured by computer-assisted sperm analysis (CASA) and the relationship to fertility. Theriogenology. 49,871-879.

Flesch, F.M., Voorhout, W.F., Colenbrander, B., van Golde, L.M., Gadella, B.M. 1998. Use of lectins to characterize plasma membrane preparations from boar spermatozoa: a novel technique for monitoring membrane purity and quantity. Biol. Reprod. 59,1530-1539.

Garner, D.L., Pinkel, D.P., Johnson, L.A., Pace, M.M. 1986. Assesment of spermatozoal function using fluorescent staining and flow cytometric analysis. Biol. Reprod. 34, 127-138.

Garner, D.L., Johnson, L.A., Allen, C.h. 1988. Fluorimetric evalution of criopreserved bovine apermatozoa extended in egg yolk and milk. Theriogenology. 30, 369-378.

Garner, D.L., Thomas, C.A., Joerg, H.W., Delarnette, M., Marshall, C.E. 1997. Fluorometric Assessments of Mitochondrial Function and Viability in Cryopreserved Bovine Spermatozoa. Biol. Reprod. 57, 1401-1406. 
Gerris, J., Khan, I. 1987. Correlation between in vitro fertilization and human sperm density and motility. J. Androl. 8, 48-54.

Harrison, R.A.P., Vickers, S.E. 1990. Use of fluorescent probes to asses membrane integrity in mammalian spermatozoa. J. Reprod. Fertil. 88, 343-352.

Heuer, J.A., King, S.S., Gardiner, C.S., Ferreira-Dias, G., Nequin, L. 1993. Uterine secretions from different endometrial classifications affect the viability of early murine embryos cultured in vitro. J. Eq. Vet. Sci. 13, 494-497.

Holt, W.; Watson, P.; Curry, M.; Holt, C. 1994. Reproducibility of computersided semen analysis: comparison of five different systems used in a practical workshop. Fertil. Steril. 62, 1277-1282.

Katila, T. 1995. Onset and duration of the uterine inflammatory response of mares after insemination with fresh semen. Biol. Reprod. Monograph. Series 1: Equine reproduction $\mathrm{VI}, 515-517$.

Katila, T. 1997. Procedures for handling fresh stallion semen. Theriogenology. 46, 1217-1227.

Katila, T.; Sankari, S.; Mäkelä, O. 2000. Transport of spermatozoa in the reproductive tracts of mares. J. Reprod. Fert. 56 (suppl), 571-8.

Kirk, E.S.; Squires, E.L.; Graham, J.K. 2005. Comparison of in vitro laboratory analyses with the fertility of cryopreserved stallion spermatozoa. Theriogenology. 64, 1422.

Kotilainen, T.; Huhtintn, M.; Katila, T. 1994. Sperm induced leukocytosis in the equine uterus. Theriogenology. 41, 629-636.

Love, C.C., Thompson, J.A., Brinsko, S.P., Rigby, S.L., Blanchard, T.L., Lowry, V.K., Varner, D.D. 2003. Relationship between stallion sperm motility and 
viability as detected by two fluorescence staining techniques using flow cytometry. Theriogenology. 60(6), 1127-1138.

Macedo, L.P., Papa, F.O., Melo, C.M., Dell'Aqua Jr, J.A., 2003. Efeitoda sazonalidade sobre os parâmetros espermáticos de garanhões de diferentes raças na região de clima subtropical úmido (Botucatu, SP/ Brasil). Acta Scientiae Veterinariae. 31, 436.

Magistrini, M.; Guitton, E.; Levern, Y.; Nicolle, J.C.; Vidament, M.; Kerboeuf, D.; Palmer, E. 1997. New staining methods for sperm evaluation estimated by microscopy and flow cytometry. Theriogenology. 48, 1229-1235.

Makler, A.; David, R.; Blumenfeld, Z.; Better, O.S. 1981. Factors affecting sperm motility. VII Sperm viability as affected by change of $\mathrm{pH}$ and osmolarity of semen and urine specimen. Fertil. Steril. 36, 507-511.

Maxwell, W.M.C.; Welch, G.R.; Johnson, L.A. 1997. Viability and membrane integrity of spermatozoa after dilution and flow cytometric sorting in the presence or absence of seminal plasma. Reprod. Fertil. Develop. 8, 1165-1178.

Melo, C.M.; Villaverde, A.I.S.B.; De Vita, B.; Alvarenga, M.A.; Dell'aqua Jr., J.A.; Crespilho, A.M.; Papa, F.O. 2008. Interactions between uterine fluid and equine frozen-thawed sêmen. In: 5th International Conference on Equine Reproductive Medicine. Leipzig...Pferdeheilkunde 5. Internationale Konferenz Equine, 2008.

Milligan, M.P.; Harris, S.; Dennis, K.J. 1980. Comparison of sperm velocity in fertile and infertile groups measured by time-lapse photography. Fertil. Steril. 34, 509-551.

Overstreet, J.W.; Cooper, G.W. 1978. Sperm transport in the reproductive tract of the female rabbit: I. The rapid transit phase of transport. Biol. Reprod. 19, 101-114. 
Papaioannou, K.Z.; Murphy, R.P.; Monks, R.S.; Hynes, N.; Ryan, M.P.; Boalnd, M.P.; Roche, J.F. 1997. Assessment of viability and mitochondrial function of equine spermatozoa using double staining and flow cytometry. Theriogenology. 48, 299-312.

Parks, E.J.; Graham, J.K. 1992. Effects of criopreservation procedures on sperm membranes. Theriogenology. 38, 209-222.

Silva, P.N.F.; Gadella, B.M. 2006. Detection of damage in mammalian sperm cells. Theriogenology. 65 , 958-978.

Scott, M.A.; Liu, I.K.M.; Overstreet, J.W. 1995. Sperm transport to the oviducts: Abnormality and their clinical implications. Proc. Am. Assoc. Eq. Pract. 41, 1-2.

Thomas, C.A.; Garner, D.I.; Dejarnette, J.K.; Marshall, C.E. 1998. Effect of Cryopreservation on Bovine Sperm Organelle Function and Viability as Determined by Flow Cytometry. Biol. Reprod. 58, 786-793.

Troedsson, M.H.T.; deMoraes, M.J.; Liu, I.K.M. 1993a. Correlations between histologic endometrial lesions in mares and clinical response to intra-uterine exposure to Streptococcus zooepidemicus. Am. J. Vet. Res. 54, 570-2.

Troedsson, M.H.T.; Liu, I.K.M.; Ing, M.; Pascoe, J.; Thurmond M. 1993b. Multiple site electromyography recordings of uterine activity following an intrauterine bacterial challenge in mares susceptible and resistant to chronic uterine infection. J. Reprod. Fertil. 99, 307-13.

Troedsson, M.H.T. 1995. Uterine response to semen deposition on the mare. In: Proceedings. Annual Meeting of the Society for Theriogenology. 130-135.

Troedsson, M.H.T; Steiger, B.N.; Ibrahim, N.M.; Foster, D.N.; Crabo, G. 1995. Mechanisms of sperm induced endometritis in the mare. Biol. Reprod. (suppl.) 52, 307. 
Troedsson, M.H.T. Diseases of the uterus. In: ROBINSON, N.E. (ED). Current therapy in equine medicine. 4.ed. Philadelphia: W.B Saunders, 1997. pp. 517524.

Troedsson, M.H.T; Liu, I.K.M.; Crabo, B.G. 1998. Sperm transport and survival in the mare: a review. Theriogenology. 50, 807-818.

Troedsson, M.H.T. 1999. Uterine clearance and resistance to persistent endometritis in the mare. Theriogenology. 52, 461-471.

Troedsson, M.H.T.; Alghamdi, A.S.; Desvousges, A.; Dahms, B.; Dow, C.A.; Hayna, J.; Valesco, R., Collahan, P.T.; Macpherson, M.L.; Pozor, M.; Buhi, W.C. 2005. Components in seminal plasma regulating sperm transport and elimination. Anim. Reprod. Sci. 89, 171-186.

Troedsson, M.H.T.; Desvousges, A.; Hansen, P.J.; Buhi, W.C. 2006. Equine seminal plasma protect live spermatozoa from PMN-binding and phagocytosis, while providing a mechanism for selective sperm elimination of apoptotic and dead spermatozoa. Anim. Reprod. Sci. 94, 60-61.

Troedsson, M.H.T.; Desvousges, A.; Macpherson, M.L., Pozor, M.P. 2008. Persistent breeding-induced endometritis. Pferdeheilkunde. 24, 56-60.

Tunnon, A.M.; Rodrigues-Martinez, H.; Hultén, C.; Magnusson, U. 1998. Concentration of total protein, albumin and immunoglobulins in undiluted uterine fluid from gynaecologically healty mares. Theriogenology. 50, 821-831.

Watson, E.D.; Stokes, C.R.; Bourne, F.J. 1987. Cellular and humoral mechanisms in mares susceptible and resistant to persistent endometritis. Vet. Immunol. Immunopath. 6, 107-121.

Verstegen, J., Iguer-Ouada, M., Onclin, K. 2002. Computer assisted semen analysers in andrology research and veterinary practice. Theriogenology. 57, 149-179. 
Zahn, F.S.; Papa, F.O.; Dell'aqua Jr, J.A.; Ferreira, J.C.P. 2001. Avaliação da variação sazonal de volume, motilidade, vigor, concentração, número total de espermatozóides, $\mathrm{pH}$ e osmolaridade do sêmen de garanhões na região e Botucatu. Rev. Bras. Reprod. Anim. 25, 201-203.

Zent, W.W.; Troedsson, M.H.T. 1998. Post breeding uterine fluid accumulation in a normal population of Thoroughbred mares: A field study. In: Proc. Am. Assoc. Eq. Practic. 44, 64-65. 


\title{
TRABALFO 2
}

\section{EFEITO DA DEXAMETASONA NA IMUNOMODULAÇÃO DA REAÇÃO INFLAMATÓRIA PÓS-COBERTURA EM ÉGUAS}

\author{
E.G. Fioratti, M.A. Alvarenga
}

\section{RESUMO}

A endometrite induzida pela cobertura é uma inflamação fisiológica responsável pela eliminação do excesso de espermatozóides e contaminantes do útero. Devido a poucas informações referentes a modulação da resposta inflamatória, o presente trabalho objetivou mensurar o efeito da dexametasona sobre a concentração de neutrófilos e sua funcionalidade no fluído uterino, achados de ultrassonografia, citologia e fertilidade nas éguas resistentes e susceptíveis a endometrite pós cobertura. Foram utilizados 3 ciclos estrais consecutivos de 15 éguas resistentes e 15 susceptíveis a endometrite persistente pós cobertura, essas foram inseminadas apenas uma vez por ciclo com $800 \times 10^{6}$ de espermatozóides viáveis. O grupo tratado local teve a dose inseminante suplementada com dexametasona, o tratado sistêmico sofreu aplicação de dexametasona venosa entre 1 e 2 horas anteriores à inseminação artificial e o grupo controle não sofreu influência medicamentosa. No momento da inseminação artificial, 8 e 24 horas após, foram realizadas imagens ultrassonográficas do útero e coletadas amostras de citologia endometrial exfoliativa. Oito e 24 horas após a cobertura foram colhidas amostras do fluído acumulado no lúmen uterino para análise. As éguas susceptíveis acumularam quantidade de líquido no lúmen uterino visualizado por ultrassonografia 2 vezes maior $(p<0,05)$, maior concentração de neutrófilos dispersos nesse líquido $(p<0,05)$ e menor recuperação embrionária quando comparadas as resistentes, porém essa diferença não ficou evidente nas amostras citológicas colhidas nos 
três momentos avaliados $(p>0,05)$ e não foi verificada diferença na funcionalidade dos neutrófilos uterinos das éguas resistentes e susceptíveis a endometrite persistente após cobertura. Os tratamentos com dexametasona não foram capazes de interferir na intensidade da resposta inflamatória, mas para as éguas susceptíveis, o tratamento com dexametasona local possibilitou um aumento de $40 \%$ na taxa de recuperção embrionária e o tratamento sistêmico duplicou o número de embriões recuperados por ciclo em comparação ao grupo controle. Mais estudos devem ser realizados utilizando um grupo maior de animais para que os resultados do presente trabalho sejam melhor compreendidos. 


\section{INTRODUÇÃO}

A resposta primária do útero a um agente exógeno se traduz em um processo inflamatório que atua delimitando a ação desse agente agressor. A inflamação aguda tem duração relativamente curta variando de minutos até 2 dias e suas características principais são a exsudação de líquido e proteínas plasmáticas (edema) e a migração de leucócitos, predominantemente neutrófilos. A proteção do organismo conferida pela reação inflamatória é representada pelo exsudato, devido ao aumento da permeabilidade capilar, e pela fagocitose (Cotran et al., 1991).

A endometrite induzida pela cobertura, ou seja, exposição ao sêmen, é uma inflamação fisiológica responsável pela eliminação do excesso de espermatozóides do trato reprodutivo feminino com o objetivo de preparar o útero para receber o embrião e torná-lo capaz de manter a gestação (Troedsson et al., 1995a; Troedsson, 1999).

Uma intensa reação inflamatória ocorre entre 4 e 24 horas após 0 contato do sêmen com útero (Rigby et al., 2001). Em fêmeas com um sistema de defesa funcional, a maioria dos produtos inflamatórios é removida do útero dentro de 24 a 36 horas após o início do processo (Asbury, 1986; LeBlanc, 2003; Troedsson, 1999). Assim sendo, enquanto muitas éguas conseguem efetivamente limpar esse excesso de células espermáticas e de subprodutos inflamatórios (éguas resitentes), outras apresentam como característica principal o processo de limpeza uterina atrasado (éguas susceptíveis) (Troedsson et al., 1993b).

Éguas susceptíveis a endometrite persistente após a cobertura (EPPC) geralmente são animais mais velhos e multíparos que apresentam o útero projetado na cavidade abdominal (LeBlanc et al., 1994), alterações inflamatórias crônicas no endométrio (Troedsson et al.,1993a), presença de fluído no lúmen uterino no diestro (Troedsson, 1995), conformação perineal ruim, cérvix anormal, processo de limpeza uterina atrasado decorrente de contrações miometriais sub-ótimas e falhas no sistema de drenagem linfática (Troedsson et al.,1993c) e uma concentração aumentada de óxido nítrico no fluído uterino luminal (Alghamdi e Troedsson, 2002). Recentemente foi 
demonstrado que a presença de mais de $2 \mathrm{~cm}$ de fluído no útero durante o estro é fator de predisposição a endometrite após a cobertura (Bucca et al., 2008).

A resposta inflamatória uterina induz à liberação de fatores de quimiotaxia e esses uma rápida migração de neutrófilos polimorfunucleares (PMNs) para o interior do lúmen uterino em um intervalo que pode variar de 30 (Kotilainem et al., 1994; Troedsson, 1997) a 60 minutos após o contato do sêmen com o útero (Katila, 1995). Esse processo inflamatório é caracterizado pela presença das células imunes e pela ativação do sistema complemento (Asbury et al., 1982; Troedsson et al., 1993a, Watson et al., 1987).

Essa condição inflamatória persistente pode favorecer a infecção do endométrio das éguas, sendo uma das causas mais importantes e freqüentes de infertilidade e de baixa eficiência reprodutiva na criação equina (Card, 1997; Nikolakopoulos \& Watson, 1999; Troedsson, 1999). A luteólise prematura e o efeito tóxico desse conteúdo uterino sobre o embrião também são responsáveis pela baixa fertilidade nas éguas susceptíveis, podendo afetar $15 \%$ dos animais em atividade reprodutiva (Zent \& Troedsson, 1998).

Os tratamentos empregados para a EPPC são baseados no uso de agentes ecbólicos e remoção mecânica do conteúdo uterino; em algumas situações além de serem pouco eficientes podem resultar em agravamento dos sinais clínicos e baixas taxas de prenhez com substanciais perdas econômicas se não forem devidamente utilizados. Vários protocolos de tratamento são atualmente utilizados visando controlar a EPPC em éguas susceptíveis, mas nenhum deles têm sido completamente eficaz. Fumuso et al (2003) demonstram a diferença na expressão de interleucinas (IL) entre éguas resistentes e susceptíveis a EPPC, posteriormente Fumuso et al (2006) encontraram um método de imunomodular a resposta inflamatória em éguas susceptíveis a EPPC diminuindo a expressão de interleucinas próinflamatórias. Trabalhos recentes demonstraram o potencial preventivo dos corticóides na imunomodulação desse processo inflamatório e na melhora das taxas de prenhez em éguas sub-férteis (Dell'aqua et al. 2006; Bucca et al., 2008). 
Devido a poucas informações referentes a modulação da resposta inflamatória, o presente trabalho objetivou mensurar o efeito da dexametasona sobre a concentração de neutrófilos e sua funcionalidade no fluído uterino livre, achados de ultrassonografia, citologia e fertilidade nas éguas resistentes e susceptíveis a EPPC.

\section{MATERIAL E MÉTODOS}

\subsection{Seleção dos animais}

Foram selecionadas 15 éguas entre 14 e 18 anos de idade, com histórico de acúmulo de fluído intra uterino após a cobertura determinado por ultrassonografia, baixa taxa de fertilidade, pobre conformação perineal e útero projetado na cavidade abdominal. As éguas selecionadas para compor o grupo das resistentes $(n=15)$ variavam entre 4 e 8 anos de idade, não apresentavam histórico de acúmulo de líquido, queda na taxa de fertilidade ou alterações anatômicas acima citadas. A característica principal das éguas resistentes foi a de não apresentar acúmulo de líquido no lúmen uterino passadas 48 horas da cobertura e histórico de queda nos índices de fertilidade.

\subsection{Colheita de sêmen e preparo das doses inseminantes}

Foi realizada colheita de sêmen com auxílio de uma vagina artificial (modelo Botucatu), regulada individualmente para cada garanhão no momento da colheita. Imediatamente após a obtenção do sêmen e a retirada da fração gel por filtração foi realizada uma diluição com produto comercial a base de leite desnatado (Botu-semen ${ }^{\circledR}$ ) na proporção de 1:1, sempre foi utilizado o mesmo diluidor para todas as amostras de sêmen utilizadas. Após essa diluição prévia, a motilidade subjetiva foi obtida por microcopia óptica em aumento de 200 vezes e a concentração foi mensurada com uso da câmara de Neubauer, realizado esse processo foi separada uma dose contendo $800 \times 10^{6}$ de espermatozóides móveis. Essa dose inseminante foi rediluída até um 
volume fixo final de $30 \mathrm{~mL}$ para os grupo controle (C) e tratado sistêmico (TS), para o grupo tratado local (TL) o diluidor da segunda diluição foi suplementado com $2 \mathrm{mg}$ de dexametasona e essa amostra foi ressuspendida até o volume de $30 \mathrm{~mL}$ para garantir uma concentração final constante de $0,067 \mathrm{mg} / \mathrm{mL}$ de dexametasona conforme descrito por Fioratti et al. (2008).

\subsection{Inseminações artificiais}

Tanto as éguas resistentes como as susceptíveis foram inseminadas em ciclos estrais consecutivos com o mesmo garanhão. O primeiro ciclo não sofreu nenhuma influência medicamentosa, sendo por isso considerado como ciclo controle; no segundo ciclo foi adicionado ao sêmen $2 \mathrm{mg}$ de dexametasona (TL) e no terceiro ciclo, no intervalo entre 1 e 2 horas previamente a inseminação artificial foi aplicado por via endovenosa $40 \mathrm{mg}$ de dexametasona (TS).

Ao se detectar um folículo de $35 \mathrm{~mm}$ e um edema uterino compatível as éguas tiveram as ovulações induzidas com $1 \mathrm{mg}$ de acetato de deslorelina (I.M.) e cada animal foi então inseminado apenas uma vez por ciclo com o número de espermatazóides e o volume total previamente estabelecido, nos ciclos em que a ovulação não ocorria dentro do período desejado as colheitas eram descartadas e o ciclo estral desconsiderado.

\subsection{Colheita e processamento do material uterino}

Após a higienização da região perineal foi realizada uma citologia uterina exfoliativa imediatamente anterior, 8 e 24 horas após, a inseminação artificial. As coletas eram feitas com auxílio de um aparelho para coleta de citologia uterina equina que tinha a função de proteger a escova ginecológica do contato com o ambiente vaginal e cervical da fêmea e facilitar sua entrada no útero conforme descrito por Alvarenga e Iwana de Matos (1990). As lâminas confeccionadas dessas coletas foram secadas em temperatura ambiente e coradas com a utilização do corante Panótico Rápido (Laborclin, Brasil). A leitura das amostras foi feita em microscopia óptica em aumento de 1000x 
(imersão) considerando a porcentagem de neutrófilos/100 células de forma aleatória.

Oito e 24 horas após a inseminação artificial, foram realizados exames ultrassonográficos para se detectar a presença de fluído acumulado no lúmem uterino na região da bifurcação dos cornos uterinos. Nesses mesmos momentos, a secreção uterina foi coletada através de um tampão de algodão (absorvente feminino modelo mini da marca $\mathrm{OB}^{\circledR}$ - Johnson \& Johnson), utilizando um aplicador especialmente preparado de aço inox. Afim de facilitar a remoção desse tampão de algodão, o mesmo teve seu puxador aumentado com fio cordonê grosso estéril, permanecendo $5 \mathrm{~cm}$ abaixo da comissura ventral da vulva, todo esse material foi manipulado sobre pano cirúrgico esterelizado com luvas cirúrgicas.

A retirada do tampão foi realizada após 30 minutos através da introdução da mão enluvada via vaginal e da tração do fio cordonê, mantendo-o protegido contra o contato com o canal vaginal da égua. Imediatamente após a retirada do tampão do interior do útero ele foi colocado em seringa estéril e pressionado até liberar o líquido absorvido em um tubo estéril graduado. A partir dessa amostra, uma alíquota foi separada para obtenção da concentração de neutrófilos $/ \mathrm{mL}$ em câmara de Neubauer e microscopia óptica, outra amostra foi separada para realização dos testes estimulado e não estimulado do NBT (tetrazolium nitroblue, Sigma-Aldrich) e verificar a capacidade de fagocitose dos neutrófilos.

\subsection{Teste de fertilidade}

A colheita de embrião foi realizada 8 dias após a verificação da ovulação e o resultado foi considerado positivo quando constatada a recuperação embrionária após lavados uterinos com ringer lactato (Halexstar, Brasil).

\subsection{Análise estatística}

Para os parâmetros medição da coluna de líquido acumulado na área da 
bifurcação uterina, volume recuperado e concentração de neutrófilos nesse fluído foram realizadas análises de covariância para as resposta no tempo 24 horas para estudar o efeito do tratamento e da classe das éguas (resistentes e susceptíveis), considerando a resposta no tempo 8 horas como variável auxiliar. Devido a grande dispersão dos valores obtidos para a concentração de neutrófilos no fluído uterino, esses tiveram que ser transformados em escala logarítmica para tornar os dados mais homogêneos. O teste do NBT teve seus valores transformados em arcoseno da raiz quadrada da proporção neutrófilos positivos para a presença de formazan (depósito do corante no citoplasma) num total de 100 neutrófilos. Para se analisar os dados obtidos a partir do exame citológico foi usada a análise de covariância, utilizando as medidas do tempo zero como variável auxiliar. Para os dados de prenhez foi utilizada a análise de regressão logística para investigar o efeito do tratamento e classe dessas éguas.

Todos os parâmetros foram analisados com nível de significância de 5\%.

\section{RESULTADOS}

A concentração de neutrófilos no fluído uterino das éguas resistentes foi significativamente menor do que a das éguas susceptíveis $(p<0,0001)$ nos dois momentos avaliados, independente dos tratamentos empregados. Realizando uma comparação entre os grupos controle, tratado local e tratado sistêmico não foi encontrada diferença $(p>0,05)$ na concentração de neutrófilos as 8 e as 24 horas após a inseminação artificial para as éguas resistentes e susceptíveis a EPPC (tabela 1). Porém, ao longo do tempo, nas resistentes a diminuição da concentração de neutrófilos foi menor para aquelas éguas submetidas ao tratamento local $(p<0,05)$ e nas susceptíveis foi observado que o tratamento sistêmico propiciou uma menor redução na concentração de neutrófilos ao longo do tempo $(p<0,05)$ (tabela 2$)$. 
Tabela 1. Valores médios \pm desvios padrão da concentração de neutrófilos/ $\mathrm{mL}$ de fluído uterino recuperado de éguas resistentes e susceptíveis após a inseminação artificial.

\begin{tabular}{ccccc}
\hline \multicolumn{4}{c}{ Concentração $(\mathrm{PMNs} / \mathrm{mL})$} \\
\hline & \multicolumn{2}{c}{ Resistentes } & \multicolumn{2}{c}{ Susceptíveis } \\
\hline 8 hs & $\mathbf{2 4}$ hs & $\mathbf{8}$ hs & 24 hs \\
\hline C & $22,56 \pm 22,73^{\mathrm{a}}$ & $2,62 \pm 1,5^{\mathrm{a}}$ & $7228,17 \pm 13692,65^{\mathrm{b}}$ & $1718,67 \pm 1860,19^{\mathrm{b}}$ \\
TL & $22,73 \pm 12,71^{\mathrm{a}}$ & $12,28 \pm 21,2^{\mathrm{a}}$ & $4548,20 \pm 5413,19^{\mathrm{b}}$ & $2488,27 \pm 3343,36^{\mathrm{b}}$ \\
& & & & \\
TS & $13,82 \pm 9,46^{\mathrm{a}}$ & $3,53 \pm 2,22^{\mathrm{a}}$ & $5846,5 \pm 6115,77^{\mathrm{b}}$ & $4992,5 \pm 3891,23^{\mathrm{b}}$ \\
\hline
\end{tabular}

a,b Letras diferentes na mesma linha indicam diferença estatística $(p>0,05)$. C, controle; TL, tratado local; TS, tratado sistêmico. PMNs*, milhões de neutrófilos.

Tabela 2. Porcentagem de redução de neutrófilos entre os momentos 8 e 24 horas após a inseminação artificial de éguas resistentes e susceptíveis a EPPC.

\begin{tabular}{|c|c|c|}
\hline & \multicolumn{2}{|c|}{ \% de Redução de PMNs } \\
\hline & Resistentes & Susceptíveis \\
\hline C & $88,4^{\mathrm{a}}$ & $76,2^{\mathrm{a}}$ \\
\hline TL & $46,0^{b}$ & $45,3^{\mathrm{a}}$ \\
\hline TS & $74,5^{\mathrm{a}, \mathrm{b}}$ & $14,6^{b}$ \\
\hline
\end{tabular}


A maior concentração de neutrófilos livres no fluído uterino foi observado para as éguas susceptíveis, contudo a presença deles nas amostras de citologia exfoliativa uterina não demonstrou diferença na resposta inflamatória entre as éguas resistentes e susceptíveis a EPPC ( $p>0,05)$. Ainda, não foi observado $(p>0,05)$ efeito dos tratamentos nos resultados obtidos pela citologia uterina colhida das éguas resistentes e susceptíveis durante as primeiras 24 horas após a cobertura (figura 1 e 2 ).

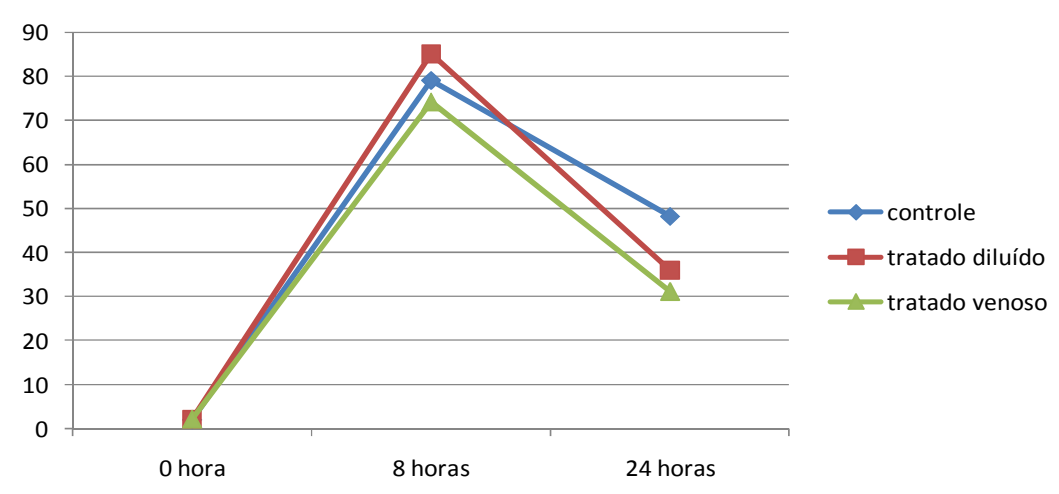

Figura 1. Porcentagem de neutrófilos observados em exame citológico ao longo do tempo analisado para as éguas resistentes a EPPC.

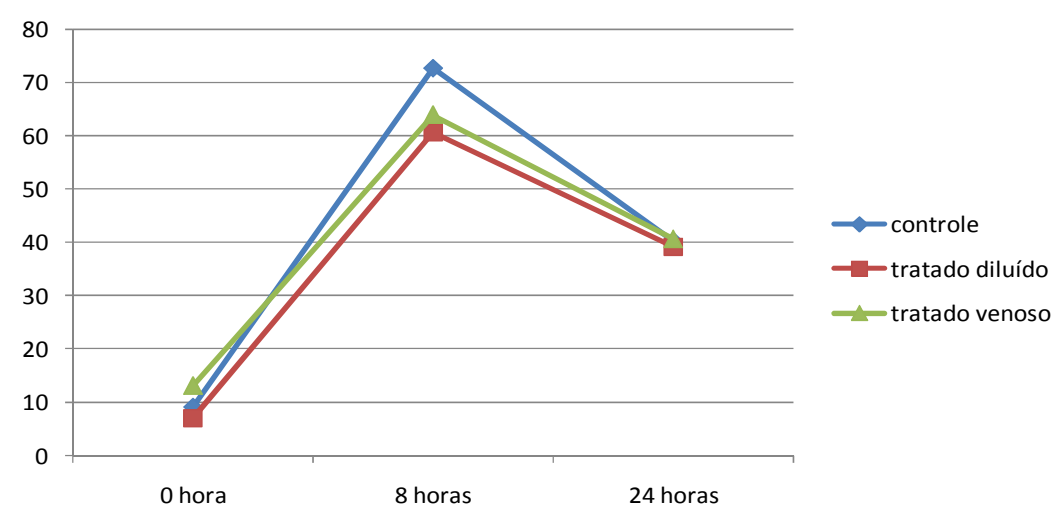

Figura 2. Porcentagem de neutrófilos observados em exame citológico ao longo do tempo analisado para as éguas susceptíveis a EPPC. 
Nenhuma diferença de funcionalidade foi constatada $(p>0,05)$ quando os neutrófilos retirados do útero de éguas resistentes e susceptíveis, tratadas oou não com dexametasona, foram submetidos aos testes estimulado e não estimulado do NBT nos momentos 8 e 24 horas após a cobertura (Tabela 3).

Tabela 3. Porcentagem de neutrófilos uterinos funcionais colhidos 8 e 24 horas após a inseminação artificial de éguas resistentes e susceptíveis a endometrite persistente pós cobertura.

\begin{tabular}{lllll}
\hline \multicolumn{2}{c}{8 horas } & \multicolumn{2}{c}{24 horas } \\
\hline NE & E & NE & E \\
\hline Resistentes & $81,8 \pm 8,8^{\mathrm{a}}$ & $68,0 \pm 11,4^{\mathrm{a}}$ & $79,8 \pm 9,7^{\mathrm{a}}$ & $69,3 \pm 10,7^{\mathrm{a}}$ \\
& & & & \\
Susceptíveis & $82,4 \pm 10,1^{\mathrm{a}}$ & $70,0 \pm 11,5^{\mathrm{a}}$ & $81,5 \pm 9,8^{\mathrm{a}}$ & $71,4 \pm 11,8^{\mathrm{a}}$ \\
\hline
\end{tabular}

${ }^{a}$ Letras diferentes na mesma linha indicam diferença estatística $(p>0,05)$. NE; teste não estimulado do NBT. E; teste estimulado do NBT.

$\mathrm{Na}$ avaliação do conteúdo uterino por ultrassonografia foi constatado que as éguas resistentes apresentavam diferença significativa quando comparadas as susceptíveis $(p<0,0003)$ em relação a presença e quantidade de líquido acumulado na região da bifurcação dos cornos uterinos, onde as éguas susceptíveis sempre apresentavam maior acúmulo de líquido do que as resistentes.

Nas éguas susceptíveis que foram submetidas ao tratamento sistêmico foi verificado que com o passar do tempo a redução de líquido acumulado foi maior quando comparado aos grupos controle $(p<0,002)$ e tratado diluído $(\mathrm{p}<0,05)$, dados apresentados na tabela 4.

Para o parâmetro volume de líquido recuperado, as éguas susceptíveis apresentaram maior coleção de exsudato $(p<0,0002)$ no lúmen uterino (figura 3) nos dois momentos de avaliação. Os tratamentos com dexametasona não foram suficientes para provocar diminuição desse volume recuperado, 
entretanto, o tratamento com dexametasona local proporcionou uma tendência em diminuir o volume de fluído recuperado nas éguas susceptíveis $(p=0,0585)$.

Tabela 4. Valores médios ( $\mathrm{mm}$ ) e porcentagem de redução (\%) da altura da coluna de líquido acumulado na região da bifurcação uterina de éguas susceptíveis a endometrite persistente pós cobertura 8 e 24 horas após a inseminação artificial.

\begin{tabular}{llll}
\hline \multicolumn{3}{c}{ Susceptíveis } \\
\hline & C & TL & TS \\
\hline $\mathbf{8}$ & $20,36 \pm 5,87^{\mathrm{a}}$ & $18,4 \pm 8,73^{\mathrm{a}}$ & $13,41 \pm 11,87^{\mathrm{a}}$ \\
\hline $\mathbf{2 4}$ & $17,98 \pm 7,62^{\mathrm{a}}$ & $16,14 \pm 7,48^{\mathrm{a}}$ & $8,98 \pm 6,67^{\mathrm{a}}$ \\
\hline Redução & $11,69 \%^{\mathrm{A}}$ & $12,28 \%^{\mathrm{A}}$ & $33,04 \%^{\mathrm{B}}$ \\
\hline
\end{tabular}

$\overline{a, A, B}$ Letras diferentes na mesma linha indicam diferença estatística significativa $(P<0.05)$. C, grupo controle; TL, grupo tratado local; TS, grupo tratado sistêmico.

A fertilidade foi aferida pela taxa de recuperação embrionária no oitavo dia após a ovulação, somente foram utilizados para o experimento os ciclos estrais com uma inseminação artificial. As taxas de recuperação embrionária não diferiram entre as éguas resistentes e suceptíveis independente dos tratamentos empregados $(p>0,05)$. Os dados da recuperação embrionária estão expostos na figura 4.

Para a classe de éguas resistentes a EPPC foram realizados 45 lavados onde se recuperou 33 embriões, que correpondem a $76,74 \%$ de resultado positivo. Em contrapartida, para as éguas susceptíveis foram recuperados 21 embriões de 43 lavados, que representam uma produtividade de $48,83 \%$. 


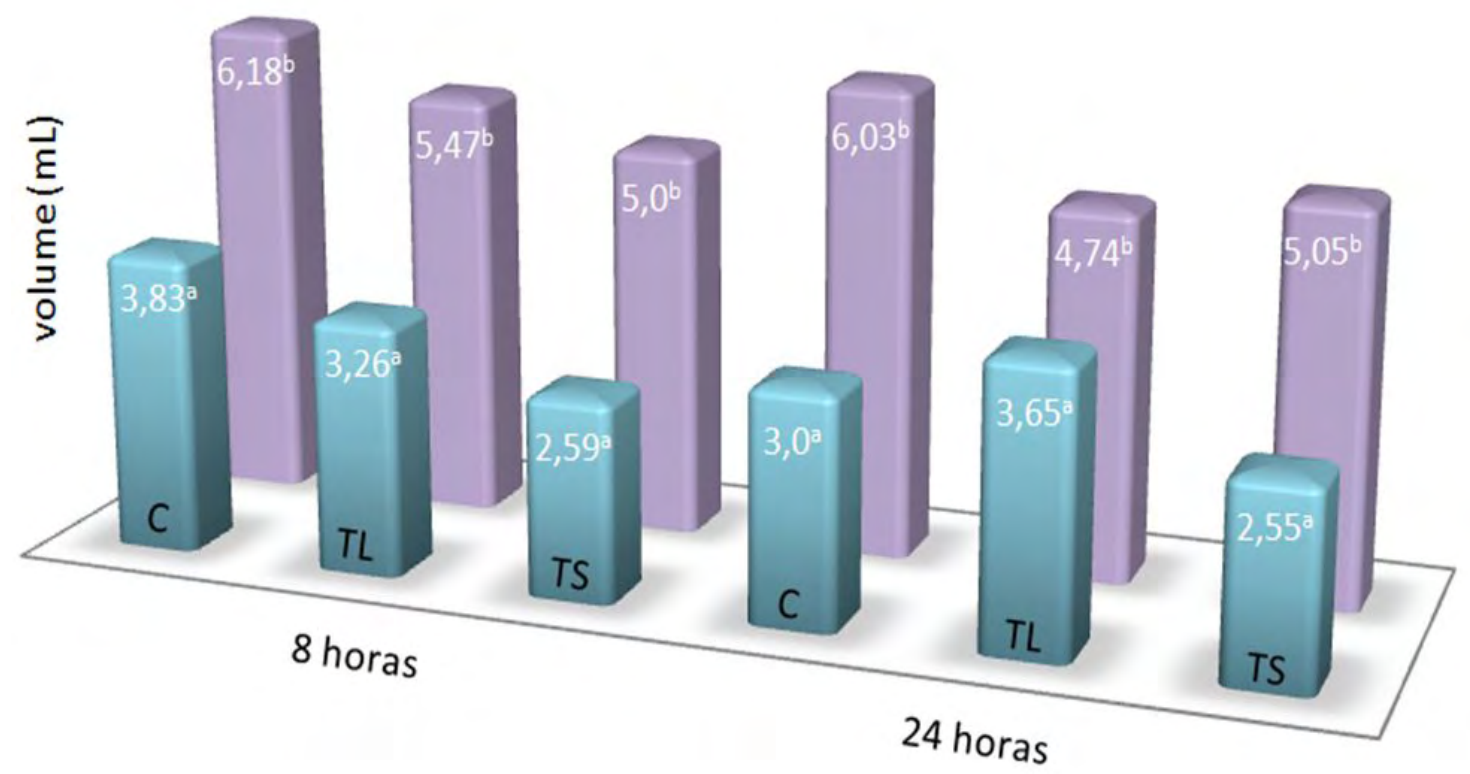

Figura 3. Média dos valores do volume de fluído uterino recuperado $(\mathrm{mL})$ pelo tampão de algodão as 8 e as 24 horas após a inseminação artificial de éguas resistentes e susceptíveis a endometrite persistente pós cobertura. C, grupo controle; TL, grupo tratado local; TS, grupo tratado sistêmico.

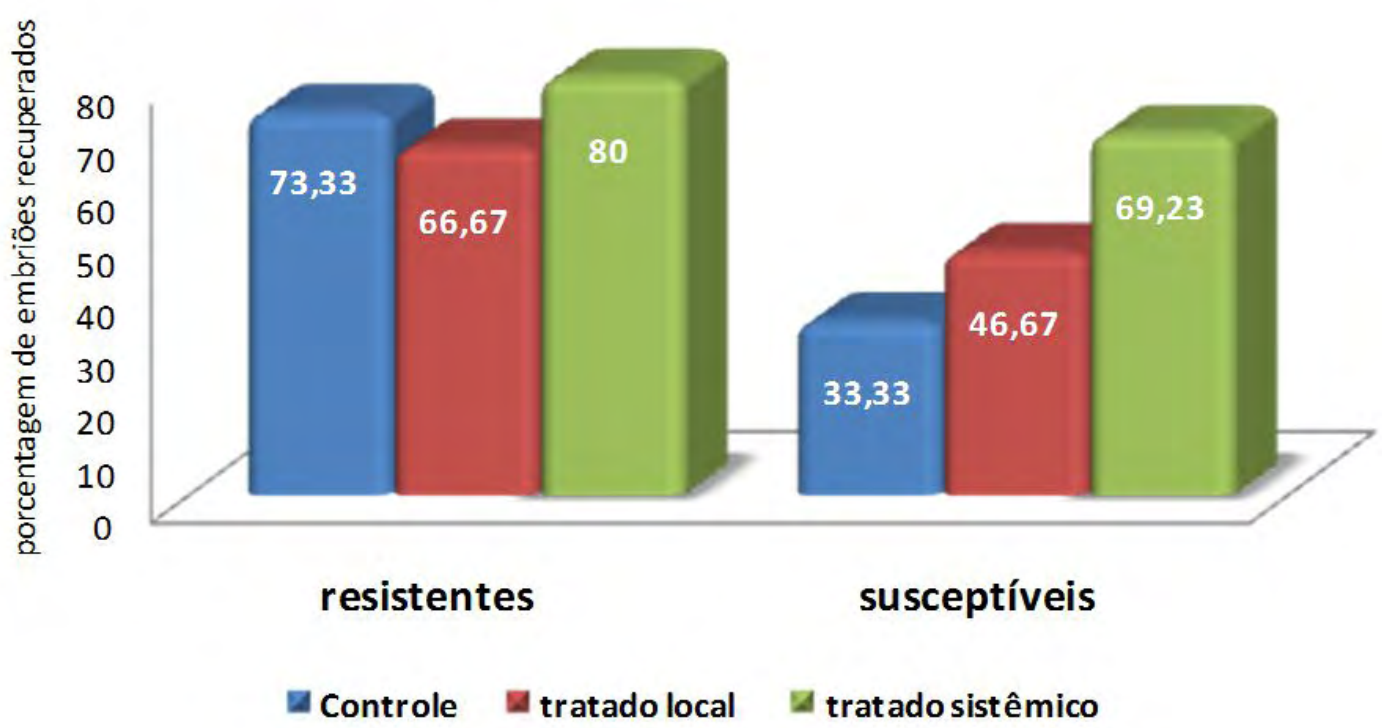

Figura 4. Porcentagem de embriões recuperados de éguas resistentes e susceptíveis a endometrite persistente pós cobertura $(p>0,05)$. 


\section{DISCUSSÃO}

No presente experimento foi observado no exame ultrassonográfico que as éguas susceptíveis acumulam praticamente o dobro da quantidade de líquido no interior do útero quando comparadas as éguas resistentes, tanto as 8 como as 24 horas após a inseminação artificial, dados que diferem dos encontrados por Troedsson \& Liu (1992) que verificaram que ao passar por um desafio bacteriano as éguas susceptíveis apresentaram acúmulo de fluído no útero 6 vezes maior do que as éguas resistentes, talvez porque esse tipo de desafio seja capaz de provocar uma exsudação mais intensa do que aquela vista em resposta a presença do sêmen.

Assim como observado por Dell'aqua (2004) a terapia com corticóide não foi capaz de diminuir o acúmulo de fluído intra uterino, discordando das observações de Bucca et al. (2008). Porém, a dexametasona sistêmica foi a que provocou uma maior redução do fluído acumulado das 8 para as 24 horas.

Foi observado neste estudo que as éguas resistentes apresentaram menor concentração de neutrófilos no fluído uterino do que as éguas susceptíveis a EPPC, discordando dos relatos de Liu et al. (1986) e Williamson et al. (1987). Apesar das éguas resistentes e susceptíveis apresentarem diferentes concentrações de PMNs no pico da inflamação, com o passar do tempo a concentração de neutrófilos no lúmen uterino de ambas dimimuiu, observações condizentes com as de Katila (1996). Porém, a concentração de PMNs ainda se mantem maior para as éguas susceptíveis 24 horas após a inseminação artificial, concordando com os achados de Katila (1995).

$\mathrm{O}$ tratamento local com dexametasona nas éguas resistentes permitiu similar influxo de neutrófilos para o lúmen uterino e, ao contrário do esperado, não permitiu redução na concentração neutrofílica correspondente aquela observada no grupo controle. Entretanto, o tratamento sistêmico proporcionou uma concentração de neutrófilos as 8 horas após a cobertura 1,6 vezes menor em comparação ao grupo controle, mas as 24 horas os valores encontrados foram similares.

Nas éguas susceptíveis os tratamentos com dexametasona diminuíram numericamente a migração de neutrófilos para o lúmen uterino 8 horas após a 
cobertura. Porém, 24 horas após a cobertura, o grupo que não foi submetido a qualquer tratamento apresentou menor quantidade absoluta dessas células, pois o tratamento sistêmico retardou o processo de redução do número de neutrófilos entre 8 e 24 horas após a cobertura. Entretanto, o número de animais usados no estudo impede que essa diferença numérica seja estatística.

A presença de um agente agressor no útero provoca um contínuo recrutamento de neutrófilos para seu interior (Liu et al., 1986; Troedsson, 1999), portanto a heterogenicidade populacional pode comprometer a verificação da funcionalidade desses neutrófilos uterinos, pois Watson et al. (1987) observaram que os neutrófilos oriundos do útero são mais efetivos na fagocitose do que aqueles derivados do sangue por já estarem ativados no útero inflamado, porém Asbury et al. (1982) relataram que o fluído uterino das éguas susceptíveis provoca uma diminuição da capacidade opsonizante dos neutrófilos. Cheung et al. (1985) e Liu et al. (1986) relataram diferenças na capacidade de migração e fagocitose de neutrófilos de éguas resistentes e susceptíveis, mas observaram que os neutrófilos da corrente sanguínea possuem a mesma competência funcional para as duas classes de éguas, fato também observado por Dell'aqua (2004) quando realizou o teste do NBT (nitroblue tetrazolium) não estimulado.

Para se verificar a funcionalidade neutrofílica, representada por sua capacidade fagocítica, no presente estudo foi realizado o teste do NBT em neutrófilos retirados diretamente do fluído uterino após sua coleta. Apesar da heterogenicidade populacional a capacidade fagocítica dessas células não apresentou diferença entre as éguas consideradas resistentes e susceptíveis a EPPC, discordando dos achados de Dell'aqua (2004) que verificou diferença na função dos neutrófilos da circulação sanguínea quando utilizou o teste do NBT estimulado. Os tratamentos com dexametasona também não influenciaram a função desses neutrófilos, concordando com o observado por Dell'aqua (2004).

Existem vários modos de interpretação das amostras citológicas coletadas do útero e métodos para sua coleta. No presente trabalho foi realizada a citologia exfoliativa com utilização de escova ginecológica e a classificação do processo inflamatório foi obtida pela relação entre células 
endometriais e neutrófilos, conforme relatado por Alvarenga e Iwana de Matos (1990). A porcentagem de neutrófilos presentes em uma amostra de citologia endometrial é usada para determinar o grau da inflamação presente no útero. Foi utilizada a classificação apresentada por Brook (1993) onde a presença de menos do que $5 \%$ de PMNs indica um endométrio não inflamado, de 5 a $15 \%$ uma inflamação média, de 15 a 30\% uma inflamação moderada e acima de $30 \%$ uma inflamação severa. Porém, a presença de qualquer outro tipo celular ou de microrganismos era sempre pesquisada.

Os parâmetros citológicos apresentados por éguas não cobertas se assemelham aqueles apresentados após a cobertura por éguas resistentes a endometrite no intervalo de 24 a 96 horas, uma vez que há uma pequena população de neutrófilos residentes no útero (Brook, 1993; Kotilainem et al., 1994). Para éguas cobertas, o pico inflamatório após a cobertura é alcançado anteriormente a 24 horas, nesse período a citologia apresenta resultado semelhante a inflamação ativa, fato observado utilizando-se a técnica de lavado uterino com pequeno volume (Card et al., 2004) e por citologia exfoliativa, nesse experimento foi verificada alta porcentagem de neutrófilos no momento considerado como pico inflamatório, 8 horas e, as 24 horas onde essa relação neutrófilos/ células endometriais ainda indicava um processo inflamatório ativo.

Kotilainen et al. (1994) relataram que em éguas resistentes não haviam neutrófilos presentes na citologia obtida pela técnica de lavado uterino com pequeno volume, mas outros autores relataram um baixo percentual de neutrófilos no mesmo tipo de animal (Card et al., 2004; Nikolakopoulos e Watson, 2000), indicando desacordos na competência da técnica. No presente trabalho, por citologia endometrial exfoliativa foi constatada a presença de neutrófilos anteriormente a inseminação artificial tanto para as éguas resistentes como para as susceptíveis. Porém, todas as éguas resistentes apresentaram citologia compatível com o aceitável para o estro enquanto algumas das éguas susceptíveis apresentavam, nesse mesmo período, mais do que $5 \%$ de neutrófilos, indicando inflamação ativa, pois segundo Card (2005), a presença de mais do que $5 \%$ de neutrófilos indica que a inflamação endometrial está ativa, no presente estudo apenas duas éguas susceptíveis 
apresentaram inflamação ( $<15 \%$ de PMNs) anteriormente à inseminação artificial, mas sem acúmulo de líquido no lúmen uterino.

Éguas com evidência de inflamação na avaliação citológica e contaminação bacteriana apresentaram menores taxas de prenhez, apesar da pequena correlação entre esses testes. Ambas, citologia endometrial e cultura bacteriana são métodos diagnósticos utilizados para identificar as éguas com endometrite, pois as taxas de prenhez diminuem quanto maior a inflamação e a infecção (Riddle et al., 2007). Entretanto, a citologia endometrial identificou duas vezes mais éguas com endometrite do que a cultura bacteriana, fato similar ao observado por Digby \& Ricketts (1982), que relataram que $91 \%$ das éguas com evidência clínica de endometrite persistente apresentaram citologia compatível, mas somente $45 \%$ das amostras foi positiva na cultura. Assim sendo, o presente trabalho focou com maior atenção os achados citológicos nos momentos avaliados, pois o perfil da resposta inflamatória traçado através da citologia endometrial exfoliativa foi semelhante para as éguas resistentes e susceptíveis a EPPC, uma vez que a relação neutrófilos/células endometriais apresentou semelhante redução ao longo do tempo para as duas classes de éguas. Assim como observado previamente por Dell'aqua (2004), os tratamentos com dexametasona não foram capazes de modificar a relação entre neutrófilos e células do endométrio para nenhum tipo de égua ou tratamento.

As taxas de prenhez são inversamente proporcionais a intensidade da inflamação endometrial, em éguas sem processo inflamatório estabelecido as taxas de prenhez são 1.3 e 3 vezes maiores quando comparadas com aquelas éguas que apresentaram inflamação moderada e severa, respectivamente (Riddle et al., 2007). No presente trabalho foram encontradas taxas de recuperação embrionária para éguas resistentes de $73.33 \%$ e para éguas susceptíveis $33.33 \%$, demonstrando que a persistência da inflamação além das 24 horas após a cobertura é prejudicial a fertilidade dos animais.

Nas éguas resistentes, não foi constatada grande diferença na recuperação embrionária ao se empregar os tratamentos, concordando com Dell'aqua et al (2006). Porém, para as éguas susceptíveis, o tratamento com dexametasona local possibilitou um aumento de $40 \%$ na recuperção 
embrionária e o tratamento sistêmico duplicou o número de embriões recuperados por ciclo em comparação ao grupo controle, porém o número de animais utilizados provavelmente não permitiu evidenciar diferença estatística e corroborar os achados de Dell'aqua et al. (2006) e Bucca et al. (2008), os quais observaram aumento no índices de fertilidade dos animais tratados com antiinflamatórios esteróides pela via sistêmica.

As diferenças entre os tratamentos local e sistêmico podem ser explicadas pelo ajuste da dosagem, uma vez que a suplementação no diluidor corresponde a dose máxima de dexametasona não deletéria aos espermatozóides, podendo ter sido insuficiente para a modulação da resposta inflamatória uterina.

Os resultados obtidos no presente trabalho permitem afirmar que nas éguas susceptíveis a intensidade da resposta inflamatória uterina pós cobertura é maior, pois elas apresentam maior acúmulo de líquido intra uterino visualizado por ultrassonografia e maior concentração de neutrófilos nesse fluído. Contudo o exame citológico até 24 horas após a cobertura é incapaz de diferenciar as éguas susceptíveis das resistentes a EPPC.

A utilização sistêmica da dexametasona proporcionou efeito benéfico na redução do líquido acumulado no interior do útero e principalmente na recuperação embrionária.

\section{REFERÊNCIAS BIBLIOGRÁFICAS}

Alghamdi, A.S.; Troedsson, M.H.T. 2002. Concentration of nitric oxide in uterine secretion from mares susceptible and resistant to chronic post-breeding endometritis. Theriogenology. 58, 445-448.

Alghamdi, A.S.; Foster, D.N.; Carlson, C.S.; Troedsson, M.H.T. 2005. Nitric oxide levels and nitric oxide synthase expression in uterine samples from mares susceptible and resistant to persistent breeding-induced endometritis. Am. J. Reprod. Immunol. 53, 230-237 
Alvarenga, M.A.; Iwana de Matos, M.C. 1990. Utilização da escova ginecológica cytobrush na coleta de material endometrial de éguas. Arq. Bras. Med. Vet. Zootec. 42, 67-68.

Al Hijji, J.; Larsson, I.; Batra, S. 2001. Effect of ovarian steroids on nitric oxide synthase in the rat uterus, cervix and vagina. Life Sci. 69, 1133-42.

Asbury, A.C.; Schultz, K.T.; Klesius, P.H.; Foster, G.N.; Washburn, S.M. 1982. Factors affecting phagocytosis of bacteria and neutrophils in the mare uterus. J. Reprod. Fertil. (Suppl). 32, 151-159.

Asbury, A.C. 1986. Endometritis in the mare. In: MORROW, D.A. (ED). Current therapy in theriogenology. 2.ed. Philadelphia: W.B. Saunders, pp. 718-722.

Bader H. 1982. An investigation of sperm migration into the oviducts of the mare. J. Reprod. Fertil. (Suppl). 32, 59-64.

Brinsko, S.P.; Varner, D.D.; Blanchard, T.L. 1991. The effect of uterine lavage performed four hours post-insemination on pregnancy rates in mares. Theriogenology. 35, 1111-1191.

Brook, D. 1993. Uterine cytology. In: McKinnon, A.O.; Voss, J.L. (ED). Equine reproduction. Philadelphia: Lea \& Febiger. pp. 246-253.

Bucca, S.; Carli, A.; Buckley; T.; Dolci, G., Fogarty, U. 2008. The use of dexamethasone administered to mares at breeding time in the modulation of persistent mating induced endometritis. Theriogenology. 70, 1093-1100.

Bulbul, A.; Yagcı, A.; Altunbas, K.; Sevimli, A.; Celik, H.A.; Karadeniz, A., Akdag, E. 2007. The role of nitric oxide in the effects of ovarian steroids on spontaneous myometrial contractility in rat. Theriogenology. 68, 1156-1168. 
Cadario, M.E.; Thatcher, W.W.; Klapstein, E.; Merrit, A.M.; Archbald, L.F.; Thatcher, M.J.; LeBlanc, M.M. 1999. Dynamics of Prostaglandin Secretion, intrauterine fluid and uterine clearance in reproductively normal mares and mares with delayed uterine clearance. Theriogenology. 52, 1181-1192.

Cameron, I.T.; Campbell, S. 1998. Nitric oxide in the endometrium. Human Reprod. Update. 4, 565-569.

Card, C. 2005. Post-breeding inflammation and endometrial cytology in mares. Theriogenology. 64, 580-588.

Card, C.E.; Carley, S.D.; Green, J.; Chirino-Trejo, M. 2004. Endometrial cytology in mares bred with frozen semen. In: Proceedings of the 50th AAEP. 505-509.

Cheung, A.T.W; Liu, I.K.M.; Walsh, E.M.; Miller, M.E. 1985. Phagocytic and killing capacity of uterine-derived polymorphonuclear leukocytes (PMNs) from mares resistant and susceptible to chronic endometritis. Am. J. Vet. Res. 46, 1938-1944.

Cotran, R.S.; Kumar, V.; Robbins, S.L. 1991. Robbins Patologia estrutural e functional. 4ed. Rio de Janeiro, Guanabara-Koogan.

Costa, R.P.R.; Ferreira-Dias, G.; Mateus, L.; Korzekwa, A.; Andronowska, A.; Platek, R.; Skarzynski, D.J. 2007. Endometrial nitric oxide production and nitric oxide synthases in the equine endometrium: Relationship with microvascular density during the estrous cycle. Dom. Anim. Endocrin. 32, 287-302.

Dell'Aqua Jr., J.A.; Papa, F.O.; Lopes, M.D., Alvarenga, M.A.; Macedo, L.P.; Melo, C.M. 2006. Modulation of acute uterine inflamatory response after artificial insemination with equine frozen semen. Anim. Reprod. Sci. 94, 270273. 
Digby, N.J.W.; Ricketts, S.W. 1982. Results of concurrent bacteriological and cytological examinations of the endometrium of mares in routine stud farm practice. J. Reprod. Fertil. Suppl. 32,181-185.

Fioratti, E.G.; Melo, C.M.; Villaverde, A.I.S.B.; Papa, F.O.; Alvarenga, M.A. 2008. Effect of a steroidal anti-inflammatory drug on the viability of equine semen cooled for 24 hours. Reprod. Dom. Anim. 43, 102.

Fumuso, E., Gigu'ere, S., Wade, J., Rogan, D., Videla-Dorna, I., Bowden, R. 2003. Endometrial IL-1, IL-6 and TNF- $\alpha$, mRNA expression in mares resistant or susceptible to post-breeding endometritis. Effects of estrous cycle, artificial insemination and immunomodulation. Vet. Immunol. Immunopathol. 96, 23-41.

Fumuso, E.; Aguilar, J.; Gigu`ere, S.; David, O.; Wade, J.; Rogan, D. 2006. Interleukin-8 (IL-8) and 10 (IL-10) mRNA transcriptions in the endometrium of normal mares and mares susceptible to persistent post-breeding endometritis. Anim. Reprod. Sci. 94, 282-285.

Galindo, A.S.D.; Kunz, T.L.; Gambarini, M.L.; Oliveira, B.D. 2003. Mecanismos de defesa uterinos na fêmea bovina. Rev. Cons. Fed. Med. Vet. 9, 49-58.

Hughes, J.P. 1980. Clinical examinations and abnormalities in the mare. In: Morrow, D.A. (ED). Current therapy in theriogenology. Philadelphia: WB Saunders. pp. 706-721.

Katila, T. 1995. Onset and duration of the uterine inflammatory response of mares after insemination with fresh semen. Biol. Reprod. Monograph. Series 1: Equine reproduction VI, 515-517.

Katila, T. Uterine defense mechanisms in the mare. 1996. Anim. Reprod. Sci. 42, 197-204. 
Katila, T.; Sankari, S.; Mäkelä, O. 2000. Transport of spermatozoa in the reproductive tracts of mares. J. Reprod. Fertil. (suppl). 56, 571-8.

Katila T. 2001. Sperm-uterine interactions: a review. Anim. Reprod. Sci. 68, 267-272.

Kenney, R.M. 1978. Cyclic and pathologic changes in the mare's endometrium as detected by biopsy, with a note on early embryonic death. J. Am. Vet. Med. Assoc. 241-262.

Knowles, R.G.; Palacios, M.; Palmer, R.M.; Moncada. S. 1989. Formation of nitric oxide from L-arginine in the central nervous system: a transduction mechanism for stimulation of the soluble guanylate cyclase. Proc. Acad. Sci. USA. 86, 5159-5162.

Kotilainen, T.; Huhtintn, M.; Katila, T. 1994. Sperm induced leukocytosis in the equine uterus. Theriogenology. 41, 629-636.

LeBlanc, M.M.; Neuwirth, L.; Mauragis, D.; Klapstein, E.; Tran, T. 1994. Oxytocin enhances clearance of radiocolloid from the uterine lumen of reproductively normal mares and mares susceptible to endometritis. Equine Vet. J. 26, 279-282.

Liu, I.K.M; Cheung, A.T.W.; Walsh, E.M.; Miller, M.E.; Lindenberg, P.M. 1985. Comparison of peripheral blood and uterine-derived polymorphonuclear leukocytes from mares resistant and susceptible to chronic endometritis: chemotactic and cell elastirnetry analysis. Am. J. Vet. Res. 46, 917-920.

Liu; I. K. M.; Cheung; A. T. W.; Walsh, E.M.; AYIN; S. 1986. The Functional Competence of Uterine-derived Polymorphonuclear Neutrophils (PMN) from Mares Resistant and Susceptible to Chronic Uterine Infection: A Sequential Migration Analysis. Biol. Reprod. 35, 1168-1174. 
Maloufi, F.; Pierson, R.; Otto, S.; Ball, C.; Card, C.E. 2002. Mares susceptible or resistant to endometritis have similar endometrial echographic and inflammatory cell reactions at 96 hours after infusion with frozen semen and extender. In: Proceedings of the 48th AAEP. 51-57.

Moira, K.O.; Zini, A.; Cheng, C.Y.; Schlegel, P.N. 1998. Human sperm endothelial nitric oxide synthase expression: correlation with sperm motility. Fertil. Steril. 70, 1143-1147.

Murad, F. 1999. Cellular signaling with nitric oxide and cyclic GMP. Braz. J. Med. Biol. Res. 32(11), 1317-27.

Nathan, C. 1992. Nitric oxide as a secretory product of mammalian cells. Faseb J. 6, 3051-64.

Nikolakopoulos, E.; Watson, E.D. 2000. Effect of infusion volume and sperm numbers on persistence of uterine inflammation in mares. Equine. Vet. J. 32, 164-166.

Nikolakopoulos, E.; Kindahl, H.; Watson, E.D. 2000a. Oxytocin and PGF2a release in mares resistant and susceptible to persistent mating-induced endometritis. J. Reprod. Fertil. Suppl. 56, 363-372.

Nikolakopoulos, E.; Kindahl, H.; Gilbert, C.L.; Goode; Watson, E.D. 2000b. Release of Oxytocin and Prostaglandin $f(2$ alpha) around teasing, natural service and associated events in the mare. Anim. Reprod. Sci. 63, 89-99.

Palm, F.; Walter, I.; Budik, S.; Aurich, C. 2006. Influence of different semen extenders and seminal plasma on the inflammatory response of the endometrium in oestrus mares. Anim. Reprod. Sci. 94, 286-289.

Riddle, W.T.; LeBlanc, M.M.; Pierce, S.W.; Stromberg, A.J. 2005. Relationships 
between pregnancy rates, uterine cytology and culture results in a Thoroughbred practice in central Kentucky. In: Proceedings of the 50th AAEP. 51-54.

Riddle, W.T.; LeBlanc, M.M.; Stromberg, A.J. 2007. Relationships between uterine culture, cytology and pregnancy rates in a Thoroughbred practice. Theriogenology. 68, 395-402.

Rigby, S.L.; Barhoumi, R.; Burghardt, R.C.; Colleran, P.; Thompsom, J.A.; Varner, D.D; Blanchard, T.L.; Brinsko, S.P.; Taylor, T.; Wilkerson, M.K.; Delp, M.D. 2001. Mares with Delayed Uterine Clearance Have an Intrinsec Defect in Myometrial Function. Biol. Reprod. 65, 740-747.

Reitzenstein, M.; Callhan, M.A.; Hansen, P.J.; LeBlanc, M.M. 2002. Aberrations in uterine contractile patterns in mares with delayed uterine clearance after administration of detomidine and oxytocin. Theriogenology. 58, 887-898.

Salvemini, D.; Misko, T.P.; Masferrer, J.L.; Seibert, K.; Currie, M.G., Needleman, P. 1993. Nitric oxide activates cyclooxygenase enzymes. Proc. Natl. Acad. Sci. USA. 90, 7240-7244.

Schmidt, H.H.W.; Gagne, G.D.; Nakane, M.; Pollock, J.S.; Miller, M.F.; Murad, F. 1992. Mapping of neural nitric oxide synthase in the rat suggests frequent colocalization with NADPH diaphorase but not with soluble guanylyl cyclase, and novel paraneural function for nitrinergic signal transduction. J. Hisotchem. Cytochem. 40, 1439-1456.

Scott, M.A.; Liu, I.K.M.; Overstreet, J.W. 1995. Sperm transport to the oviducts: Abnormality and their clinical implications. Proc. Am. Assoc. Eq. Pract. 41, 1-2.

Skarzynski, D.J.; Kobayashi, S.; Okuda, K. 2000. Influence of nitric oxide and noradrenaline on prostaglandin F2 $\alpha$ induced oxytocin secretion and intracellular 
calcium mobilization in cultured bovine luteal cells. Biol. Reprod. 63, 10001005.

Troedsson, M.H.T.; Liu, I.K.M., 1992. Measurement of total volume and protein concentration of intrauterine secretion after intrauterine inoculation of bacteria in mares that were either resistant or susceptible to chronic infection. Am. J. Vet. Res. 53, 1641- 1644.

Troedsson, M.H.T.; deMoraes, M.J.; Liu, I.K.M. 1993a. Correlations between histologic endometrial lesions in mares and clinical response to intra-uterine exposure to Streptococcus zooepidemicus. Am. J. Vet. Res. 54, 570-572.

Troedsson, M.H.T.; Liu, I.K.; Thurmond, M. 1993b. Function of uterine and blood-derived polymorphonuclear neutrophils in mares susceptible and resistant to chronic uterine infection: phagocytosis and chemotaxis. Biol. Reprod. 49, 507-514.

Troedsson, M.H.T.; Liu, I.K.; Ing, M.; Pascoe, J.; Thurmond, M. 1993c. Multiple site electromyography recordings of uterine activity following an intrauterine bacterial challenge inmares susceptible and resistant to chronic uterine infection. J. Reprod. Fertil. 99, 307-313.

Troedsson, M.H.T. 1995. Uterine response to semen deposition on the mare. In: Proceedings. The Annual Meeting of the Society for Theriogenology. 130135.

Troedsson, M.H.T.; Liu, I.K.M.; Ing, M.; Pascoe, J. 1995a. Smooth muscle electrical activity in the oviduct, and the effect of oxitocin, prostaglandin F2a and prostaglandin E2 on the myometrium and the oviduct of the cycling mare. Biol. Reprod. Monogr. 1, 475-488. 
Troedsson, M.H.T.; Crabo, B.G.; Ibrahim, N.M.; Scott, M.; Ing, M. 1995b. Mating-induced endometritis: mechanisms, clinical importance, and consequences. Proc. AAEP. 41, 11-12.

Troedsson, M.H.T. 1997. Diseases of the uterus. In: Robinson, N.E. (ED) Current therapy in equine medicine. 4.ed. Philadelphia: W.B Saunders, pp. 517-524.

Troedsson, M.H.T. 1999. Uterine clearance and resistance to persistent endometritis in the mare. Theriogenology. 52, 461-471.

Veronesi, M.C.; Carllucio, A.; Kindhal, H.; Faustini, M.; Battocchio, M.; Cairoli, F. 2006. Oxycitocin-induced PGF $2 \alpha$ Release in Mares With and Without Postbreeding Delayed Uterine Clearance. J. Vet. Med. 53, 259-262.

Watson, E.D.; Stokes, C.R.; Bourne, F.J. 1987. Cellular and humoral mechanisms in mares susceptible and resistant to persistent endometritis. Vet. Immunol. Immunopath. 6, 107-121.

Washburn, S.M., Klesius, P.H., Ganjam, V.K. and Brown, B.G., 1982. Effect of estrogen and progesterone on the phagocytic response of ovariectomized mares infected in utero with P-hemolytic streptococci. Am. J. Vet. Res. 43, 1367-1370.

Welter, H.; Bollwein, H.; Weber, F.; Rohn, S., Einspanier, R. 2004. Expression of endothelial and inducible nitric oxide synthases is modulated in the endometrium of cyclic and early pregnant mares. Reprod. Fertil. Dev. 16, 689698.

Wheeler, M.A.; Smith, S.D.; Garcia-Cardena, G.; Nathan, C.F.; Weiss, R.M.; Sessa, W.C. 1997. Bacterial infection induces nitric oxide synthase in human neutrophils. J. Clin. Invest. 99, 110-116. 
Williamson, P., Munya, S., Martin, R. and Penhale, J., 1987. Dynamics of the acute uterine response to infection, endotoxin infusion and physical manipulation of the reproductive tract in the mare. J. Reprod. Fertil., Suppl. 35, 317-325.

Yallampalli, C.; Garfield, R.E.; Byam-Smith, M. 1993. Nitric oxide inhibits uterine contractility during pregnancy but not during delivery. Endocrinology. 133, 1899-1902.

Zent, W.W.; Troedsson, M.H.T. 1998. Post breeding uterine fluid accumulation in a normal population of Thoroughbred mares: a field study. In: Proc. AAEP. 44, 64-65. 


\title{
TRABALHO 3
}

\section{EFEITO DA DEXAMETASONA NA CONCENTRAÇÃO DE NEUTRÓFILOS E ÓXIDO NÍTRICO NO FLUÍDO UTERINO DAS ÉGUAS}

\author{
E.G. Fioratti, M.A. Alvarenga
}

\section{RESUMO}

A endometrite induzida pela cobertura é uma inflamação fisiológica que serve para eliminar o excesso de sêmen e preparar o útero para a gestação. As contrações miometriais são de grande importância para a limpeza uterina, porém elas são fortemente influenciadas pelos mediadores inflamatórios, dessa forma, a atividade miometrial diminuída está em grande parte relacionada a presença de óxido nítrico. O presente estudo objetivou verificar a influência da dexametasona na concentração neutrofílica e de óxido nítrico no fluído uterino coletado 8 e 24 horas após a inseminação artificial de éguas resistentes e susceptíveis a endometrite induzida pela cobertura. Para isso foram utilizados 3 ciclos estrais consecutivos de 15 éguas resistentes e 15 susceptíveis, essas foram inseminadas apenas uma vez por ciclo com $800 \times 10^{6}$ de espermatozóides viáveis. O grupo tratado local teve a dose inseminante suplementada com dexametasona, o tratado sistêmico sofreu aplicação de dexametasona venosa entre 1 e 2 horas anteriores à inseminação artificial e o grupo controle não sofreu influência medicamentosa. Oito e 24 horas após a cobertura foram colhidas amostras do fluído acumulado no lúmen uterino para verificar a concentração de neutrófilos em câmara de Neubauer e de óxido nítrico pelo método de reação colorimétrica de Griess. Não foi verificada influência dos tratamentos na concentração neutrofílica no fluído recuperado do útero das éguas $(p>0,05)$, porém, as éguas susceptíveis apresentam maior concentração dessas células $(p<0,05)$ quando comparadas as resistentes, demosntrando a maior intensidade da resposta inflamatória após a cobertura. 
Oito horas após a cobertura foi verificado que as éguas susceptíveis apresentam concentração de óxido nítrico superior as resistentes $(p<0,05)$ e que os tratamentos com dexametasona não foram capazes de influenciar na produção e liberação desse mediador inflamatório. Contudo, 24 horas após a cobertura, a concentração de óxido nítrico apresentada pelas éguas resistentes era semelhante a das susceptíveis $(p>0,05)$, exceto no grupo tratado com dexametasona local diluída no sêmen, pois o contato direto dessa droga com o endométrio inflamado pode ter sido mais eficiente no combate a produção endotelial de óxido nítrico. Mais estudos são necessários para determinar o mecanismo de produção e liberação de óxido nítrico nas éguas.

Palavras-chave: égua, endometrite, dexametasona, óxido nítrico. 


\section{INTRODUÇÃO}

A endometrite induzida pela cobertura é uma inflamação fisiológica responsável pela eliminação do excesso de sêmen do trato reprodutivo da fêmea com o objetivo de preparar esse útero para receber o embrião e torná-lo capaz de manter uma gestação (Troedsson et al., 1995a; Troedsson, 1999). Enquanto a maioria das éguas consegue efetivamente limpar esse excesso de células espermáticas e de subprodutos inflamatórios do útero em até 48 horas (éguas resistentes), outras apresentam como característica principal esse processo de limpeza uterina atrasado (éguas susceptíveis) (Troedsson et al., 1993b).

A susceptibilidade à endometrite persistente pós cobertura (EPPC) afeta entre 10 e 15\% das éguas em reprodução (Zent and Troedsson, 1998), principalmente doadoras de embrião (Losinno e Alvarenga, 2006). As éguas susceptíveis geralmente são mais velhas e multíparas com o útero projetado para a cavidade abdominal (LeBlanc et al., 1994), podem apresentar alterações inflamatórias crônicas no endométrio (Troedsson et al.,1993a), presença de fluído no lúmen uterino no diestro (Troedsson, 1995), conformação perineal ruim, cérvix anormal, processo de limpeza uterina atrasado decorrente de contrações miometriais sub-ótimas e falhas no sistema de drenagem linfática (Troedsson et al.,1993c) e uma concentração aumentada de óxido nítrico no fluído uterino luminal (Alghamdi e Troedsson, 2002). Além disso, a presença superior a $2 \mathrm{~cm}$ de fluído no útero durante o estro é considerado forte indicador de predisposição a endometrite após a cobertura (Bucca et al., 2008).

Os espermatozóides no útero são carreados até o oviduto (4 horas), mas apenas uma pequena parte deles efetivamente alcançará o oviduto (Bader, 1982; Brinsko et al., 1992; Scott et al., 1995). Concomitante ao transporte espermático o excedente de espermatozóides passa a ser eliminado por contrações miometriais, através do cérvix (Katila et al., 2000) ou por fagocitose pelos neutrófilos polimorfonucleares (PMNs) (Troedsson et al., 1999).

Nas primeiras 6 horas após o contato com o sêmen o útero responde com aumento das contações miometriais. Entretanto, nas éguas resistentes a inflamação persistente a atividade muscular uterina continua aumentada entre 
7 e 19 horas após a cobertura. Porém, nas éguas susceptíveis ocorre uma diminuição da atividade contrátil que permanece abaixo da linha basal nesse intervalo (Troedsson et al., 1993c). Dessa forma, as contrações miometriais diminuídas dos animais susceptíveis coincide com o pico da resposta inflamatória gerada pelos espermatozóides, uma vez que esse pico ocorre entre 6 e 12 horas após a cobertura (Katila, 1996).

Outro mecanismo de resposta uterina é a liberação de fatores quimiotáticos pelo endométrio agredido durante a inflamação para as células do sistema imune, resultando em uma rápida migração de neutrófilos polimorfonucleares (PMNs) para o interior do lúmen uterino que se inicia em um intervalo que pode variar de 30 (Kotilainem et al., 1994; Troedsson, 1997) a 60 minutos após o contato do sêmen com o útero (Katila, 1995). Esse processo inflamatório é caracterizado pela presença das células imunes e pela ativação do sistema complemento (Asbury et al., 1982; Troedsson et al., 1993a, Watson et al., 1987).

A inflamação resulta na produção e liberação de diferentes mediadores inflamatórios. Porém, os subprodutos inflamatórios capazes de interferir diretamente na atividade contrátil miometrial são as prostaglandinas, principalmente a do tipo F2a (PGF2a) e o óxido nítrico (ON), a primeira aumentando (Cadario et al., 1999) e o segundo diminuindo a atividade da musculatura uterina (Alghamdi e Troedsson, 2002).

O óxido nítrico é um gás formado através da conversão da L-arginina na presença de oxigênio e diversos co-fatores pela ação da óxido nítrico-sintetase (NOS) (Knowles et al., 1989; Al Hijji et a., 2001). O ON tem sido identificado como um importante mensageiro intra e intercelular que controla vários processos, como o tônus vascular, a neurotransmissão, produção de hormônios, diferenciação celular, expressão gênica, a ativação de células do sistema imune e a fisiologia ovariana (Moira et al; 1998), estas ações dependem da produção local e da disponibilidade da NOS, já que o ON é rapidamente consumido (Murad, 1999).

Uma vez que não foram observadas diferenças sistêmicas nas concentrações de ocitocina e a PGF2a entre as éguas susceptíveis e resistentes após a inseminação artificial (Nikolakopoulos et al., 2000a) acredita- 
se que o ON, por ser um mediador de atividade contrátil da musculatura lisa possa induzir o relaxamento dessa no útero e por consequência provocar inibição das contrações miometriais (Yallampalli et al., 1993; Hoffmann et al., 2003; Cameron \& Campbell, 1998).

Uma das funções de maior importância do $\mathrm{ON}$ na fisiologia reprodutiva é regular a contratilidade uterina espontânea (Buhimschi et al., 1995). O nível de ON sintetizado através da NOS varia de acordo com as diferentes circunstâncias fisiológicas e patológicas, causando assim mudanças nos padrões dessas contrações espontâneas (Jablonka-Shariff et a., 1999; Saxena et al., 2000). Estudos in vitro demonstram a capacidade do ON em diminuir ou inibir (Yallampali et al., 1993) as contrações uterinas dependendo da fase do período menstrual ou gestacional em mulheres. $\mathrm{O} O \mathrm{ON}$ inibe a contração dos músculos lisos via ativação da guanilato ciclase, essa enzima se encontra difundida nas células dos músculos lisos (Buhimschi et al., 1995) e, uma vez ativada, provoca um aumento nos níveis de cGMP e, conseqüentemente, relaxamento da musculatura lisa (Anggard, 1992).

A enzima que controla a produção do $\mathrm{ON}$ foi encontrada sob três formas homólogas: iNOS (indutora), eNOS (endotelial) e nNOS (neuronal) (Nathan, 1992) que estão presentes em diferentes tecidos (Saxena et al., 2000). Tanto na superfície do epitélio glandular como nas células do tecido conjuntivo do endométrio e miométrio foram identificadas diversas expressões dessas enzimas. Além disso, a expressão da nNOS e eNOS estava presente em fibras nervosas e a expressão da nNOS e iNOS foi detectada no endotélio vascular e no músculo liso do útero. No entanto, a expressão da iNOS não foi observada nas fibras nervosas (Bulbul et al., 2007).

Vários protocolos de tratamento são atualmente utilizados visando controlar a EPPC em éguas susceptíveis, mas nenhum deles têm sido completamente eficaz. Fumuso et al (2003) demonstraram a diferença na expressão de interleucinas (IL) entre éguas resistentes e susceptíveis a EPPC, posteriormente Fumuso et al (2006) encontraram um método de imunomodular a resposta inflamatória em éguas susceptíveis a EPPC. Trabalhos recentes demonstraram o potencial preventivo dos corticóides na diminuição da 
severidade da inflamação pós cobertura e melhora das taxas de prenhez em éguas sub-férteis (Dell'Aqua et al. 2006; Bucca et al., 2008).

O objetivo do presente trabalho foi comparar os níveis de óxido nítrico 8 e 24 horas após a inseminação artificial e verificar sua correlação com a concentração de neutrófilos nos mesmos momentos, além de verificar a influência dos tratamentos com dexametasona local e sistêmica na concentração de neutrófilos e óxido nítrico no fluído acumulado no lúmen uterino.

\section{MATERIAL E MÉTODOS}

\subsection{Seleção dos animais}

Foram selecionadas 15 éguas entre 14 e 18 anos de idade, com histórico de acúmulo de fluído intra uterino após a cobertura determinado por ultrassonografia, baixa taxa de fertilidade, pobre conformação perineal e útero projetado na cavidade abdominal. As éguas selecionadas para compor o grupo das resistentes $(n=15)$ variavam entre 4 e 8 anos de idade, não apresentavam histórico de acúmulo de líquido, queda na taxa de fertilidade ou alterações anatômicas acima citadas. A característica principal das éguas resistentes foi a de não apresentar acúmulo de líquido no lúmen uterino passadas 48 horas da cobertura e histórico de queda nos índices de fertilidade.

\subsection{Colheita de sêmen e preparo das doses inseminantes}

Foi realizada colheita de sêmen com auxílio de uma vagina artificial (modelo Botucatu), regulada individualmente para cada garanhão no momento da colheita. Imediatamente após a obtenção do sêmen e a retirada da fração gel por filtração foi realizada uma diluição com diluidor comercial a base de leite desnatado na proporção de 1:1, sempre foi utilizado o mesmo diluidor para todas as amostras de sêmen utilizadas. Após essa diluição prévia, a motilidade subjetiva foi obtida por microcopia óptica em aumento de 200 vezes e a 
concentração espermática foi mensurada com uso da câmara de Neubauer, realizado esse processo foi separada uma dose contendo $800 \times 10^{6}$ de espermatozóides móveis. Essa dose inseminante foi rediluída até um volume fixo final de $30 \mathrm{~mL}$ para os grupo controle (C) e tratado sistêmico (TS), para o grupo tratado local (TL) o extensor da segunda diluição foi suplementado com $2 \mathrm{mg}$ de dexametasona e essa amostra foi ressuspendiada até o volume de $30 \mathrm{~mL}$ para garantir uma concentração final constante de $0,067 \mathrm{mg} / \mathrm{mL}$ de dexametasona (Fioratti et al., 2008).

\subsection{Inseminações artificiais}

Tanto as éguas resistentes como as susceptíveis foram inseminadas em ciclos estrais consecutivos com o mesmo garanhão. O primeiro ciclo não sofreu nenhuma influência medicamentosa, sendo por isso considerado como ciclo controle; no segundo ciclo foi adicionado ao sêmen $2 \mathrm{mg}$ de dexametasona (TL) e no terceiro ciclo, no intervalo entre 1 e 2 horas previamente a inseminação artificial foi aplicado por via endovenosa $40 \mathrm{mg}$ de dexametasona (TS).

Ao se detectar um folículo de $35 \mathrm{~mm}$ e um edema uterino compatível as éguas tiveram as ovulações induzidas com $1 \mathrm{mg}$ de deslorelina (I.M.) e cada animal foi então inseminado apenas uma vez por ciclo com o número de espermatazóides e o volume total previamente estabelecido, nos ciclos em que a ovulação não ocorria dentro do período desejado as colheitas eram descartadas e o ciclo estral desconsiderado.

\subsection{Colheita de material uterino}

Oito e 24 horas após a inseminação artificial, foram realizados exames ultrassonográficos para se detectar a presença de fluído acumulado no lúmem uterino. Nesses mesmos momentos, as amostras de fluído uterino foram obtidas através da introdução de um absorvente feminino modelo mini da marca $\mathrm{OB}^{\circledR}$ (Johnson \& Johnson), utilizando um aplicador especialmente preparado de aço inox. Afim de facilitar a remoção desse tampão de algodão, o mesmo teve seu puxador aumentado com fio cordonê grosso estéril, 
permanecendo $5 \mathrm{~cm}$ abaixo da comissura ventral da vulva, todo esse material foi manipulado sobre pano cirúrgico esterelizado com luvas cirúrgicas.

A retirada do tampão foi realizada através da introdução da mão enluvada via vaginal e da tração do fio cordonê, mantendo-o protegido contra o contato com o canal vaginal da égua. Imediatamente após a retirada do tampão do interior do útero ele foi colocado em seringa estéril e pressionado até liberar o líquido absorvido em um tubo estéril. A partir dessa amostra, uma alíquota foi separada para obtenção da concentração de neutrófilos $/ \mathrm{mL}$ em câmara de Neubauer e microscopia óptica, o restante obtido foi submetido a um processo de centrifugação a $3000 \times \mathrm{xg}$ por 10 minutos, para retirada da grande quantidade de células presentes, e as amostras foram então congeladas a temperatura de $-20^{\circ} \mathrm{C}$ até o momento da dosagem dos metabólitos do ON.

\subsection{Dosagem de óxido nítrico}

A partir da descongelação das amostras as concentrações de nitrato $\left(\mathrm{NO}_{3}{ }^{-}\right)$e nitrito $\left(\mathrm{NO}_{2}{ }^{-}\right)$foram determinadas pelo método da reação colorimétrica de Griess em um espectofotometro (Multiskan EX Primary EIA V 2.1-0) com absorbância de cor em 540 nm para estimar a concentração de ON total.

Partindo do princípio estabelecido que a congelação das amostras não muda a concentração do $\mathrm{ON}$, as concentrações de nitrato e nitrito foram realizadas da seguinte maneira. A primeira reação na amostra ocorreu quando o nitrito forma o sal de diazonium, que reage com o segundo reagente para gerar a cor roxa, para a qual o pico de absorbância é de $540 \mathrm{~nm}$. Com o objetivo de reduzir o nitrato a nitrito, uma alíquota de $40 \mu \mathrm{L}$ da amostra armazenada foi incubada em mistura contendo $1000 \mu \mathrm{L}$ de nitrato reductase, $1000 \mu \mathrm{L}$ do cofator NADPH $(5 \mathrm{mg} / \mathrm{mL})$ diluído em água deionizada e $1000 \mu \mathrm{L}$ de PBS $(0,5 \mathrm{M})$. As amostras foram então encubadas numa temperatura de $37^{\circ} \mathrm{C}$ por um intervalo de 14 a 16 horas numa placa de 96 poços. Após isso, 80 $\mu \mathrm{L}$ do reagente de Griess foi adicionado a amostra. Todas as soluções foram completamente protegidas da luz durante o experimento. A curva padrão para o nitrito foi diluída em PBS contendo concentrações variando entre 0,5 a 400 $\mu \mathrm{M}$. Os valores de absorbância adquiridos nas concentrações pré 
estabelecidas foram usados para construir a curva de dispersão. A relação entre a absorbância e a concentração seguiram um padrão linear ( $R 2=0.98$; $p<0.05)$.

Dessa forma, foram realizadas as dosagens de nitrito, o metabólito de menor concentração e de ON total, ou seja, nitrito e nitrato. As reações fazem com que todo nitrato seja reduzido a nitrito e por medições desse obtemos a quantidade total de metabólitos $\left(\mathrm{NO}^{2-}\right.$ e $\left.\mathrm{NO}^{3-}\right)$.

\subsection{Análise estatística}

Devido a grande dispersão dos valores obtidos para a concentração de neutrófilos no fluído uterino, esses tiveram que ser transformados em escala logarítmica para tornar os dados mais homogêneos, posteriormente foi realizada a análise de covariância. As comparações entre os momentos 8 e 24 horas dentro de cada grupo para as éguas resistentes e susceptíveis e entre elas em relação ao mesmo momento e grupo (C, TL, TS) foram realizadas utilizando o teste t. Objetivando verificar o sucesso dos tratamentos, os resultados obtidos para as éguas resistentes e susceptíveis no mesmo momento foi analisado através de ANOVA e teste de Tukey. Para se verificar a correlação entre concentração de neutrófilos e de NO nos diversos momentos, grupos e classes de éguas foi utilizado o teste de correlação de Pearson. Todos os parâmetros analisados seguiram o nível de significância de 5\%.

\section{RESULTADOS}

A concentração de neutrófilos no fluído uterino das éguas resistentes foi significativamente menor do que a das éguas susceptíveis $(p<0,0001)$ nos dois momentos avaliados, independente dos tratamentos empregados. Realizando uma comparação entre os grupos controle, tratado local e tratado sistêmico não foi encontrada diferença $(p>0,05)$ na concentração de neutrófilos as 8 e as 24 horas após a inseminação artificial para as éguas resistentes e susceptíveis a EPPC (tabela 1). Porém, ao longo do tempo, nas resistentes a diminuição da 
concentração de neutrófilos foi menor para aquelas éguas submetidas ao tratamento local $(p<0,05)$ e nas susceptíveis foi observado que o tratamento sistêmico propiciou uma menor redução na concentração de neutrófilos ao longo do tempo $(\mathrm{p}<0,05)$ (tabela 2$)$.

Tabela 1. Valores médios \pm desvio padrão da concentração de neutrófilos/ $\mathrm{mL}$ de fluído uterino recuperado de éguas resistentes e susceptíveis após a inseminação artificial.

\section{Concentração (PMNs*/mL)}

\begin{tabular}{lcccc}
\hline & \multicolumn{2}{c}{ Resistentes } & \multicolumn{2}{c}{ Susceptíveis } \\
\hline & $\mathbf{8}$ hs & $\mathbf{2 4}$ hs & $\mathbf{8}$ hs & $\mathbf{2 4}$ hs \\
\hline C & $22,56 \pm 22,73^{\mathrm{a}}$ & $2,62 \pm 1,5^{\mathrm{a}}$ & $7228,17 \pm 13692,65^{\mathrm{b}}$ & $1718,67 \pm 1860,19^{\mathrm{b}}$ \\
TL & $22,73 \pm 12,71^{\mathrm{a}}$ & $12,28 \pm 21,2^{\mathrm{a}}$ & $4548,20 \pm 5413,19^{\mathrm{b}}$ & $2488,27 \pm 3343,36^{\mathrm{b}}$ \\
& & & \\
TS & $13,82 \pm 9,46^{\mathrm{a}}$ & $3,53 \pm 2,22^{\mathrm{a}}$ & $5846,5 \pm 6115,77^{\mathrm{b}}$ & $4992,5 \pm 3891,23^{\mathrm{b}}$ \\
\hline a,0 & Letras diferentes na mesma linha indicam diferença estatística (p>0,05). C, controle; TL, \\
tratado local; TS, tratado sistêmico. PMNs*, milhões de neutrófilos.
\end{tabular}

Comparando a concentração de $\mathrm{ON}$ do fluído uterino das éguas resistentes e susceptíveis, 8 horas após a inseminação artificial a concentração de ON estava inferior em todos os grupos das éguas resistentes $(p<0,01)$, mas 24 horas após a cobertura foi verificada similaridade entre a concentração de ON dos grupos controle e tratado sistêmico das éguas resistentes e susceptíveis a EPPC $(p>0,05)$. 
Tabela 2. Porcentagem de redução de neutrófilos entre os momentos 8 e 24 horas após a inseminação artificial de éguas resistentes e susceptíveis a endometrite persistente pós cobertura.

\begin{tabular}{|c|c|c|}
\hline & \multicolumn{2}{|c|}{ \% de Redução de PMNs } \\
\hline & Resistentes & Susceptíveis \\
\hline C & $88,4^{\mathrm{a}}$ & $76,2^{\mathrm{a}}$ \\
\hline TL & $46,0^{b}$ & $45,3^{\mathrm{a}}$ \\
\hline TS & $74,5^{\mathrm{a}, \mathrm{b}}$ & $14,6^{\mathrm{b}}$ \\
\hline
\end{tabular}

Para as éguas resistentes não foi observada diferença na concentração de ON no fluído uterino entre os grupos, entretanto ocorreu um aumento nessa concentração ao longo do período avaliado para o grupo controle $(p<0,001)$ e tratado sistêmico $(p<0,05)$, mas para as éguas submetidas ao tratamento local valores similares entre os dois momentos foram observados (Figura 1). Para as éguas susceptíveis não foram observadas diferenças na concentração de ON ao longo do tempo independentemente dos tratamentos empregados ( $p>0,05)$.

Não foi observada correlação entre as concentrações de neutrófilo e de $\mathrm{ON}$, tanto para as éguas resistentes como para as susceptíveis nos 3 grupos de avaliação. Somente no momento 24 horas, para as éguas resistentes, foi verificada uma leve correlação para o grupo controle $(r=0,09)$ e uma correlação moderada para o grupo tratado local $(r=0,78)$, porém a confiabilidade adquirida pela dispersão dos parâmetros analisados é pequena $(p>0,05)$. 


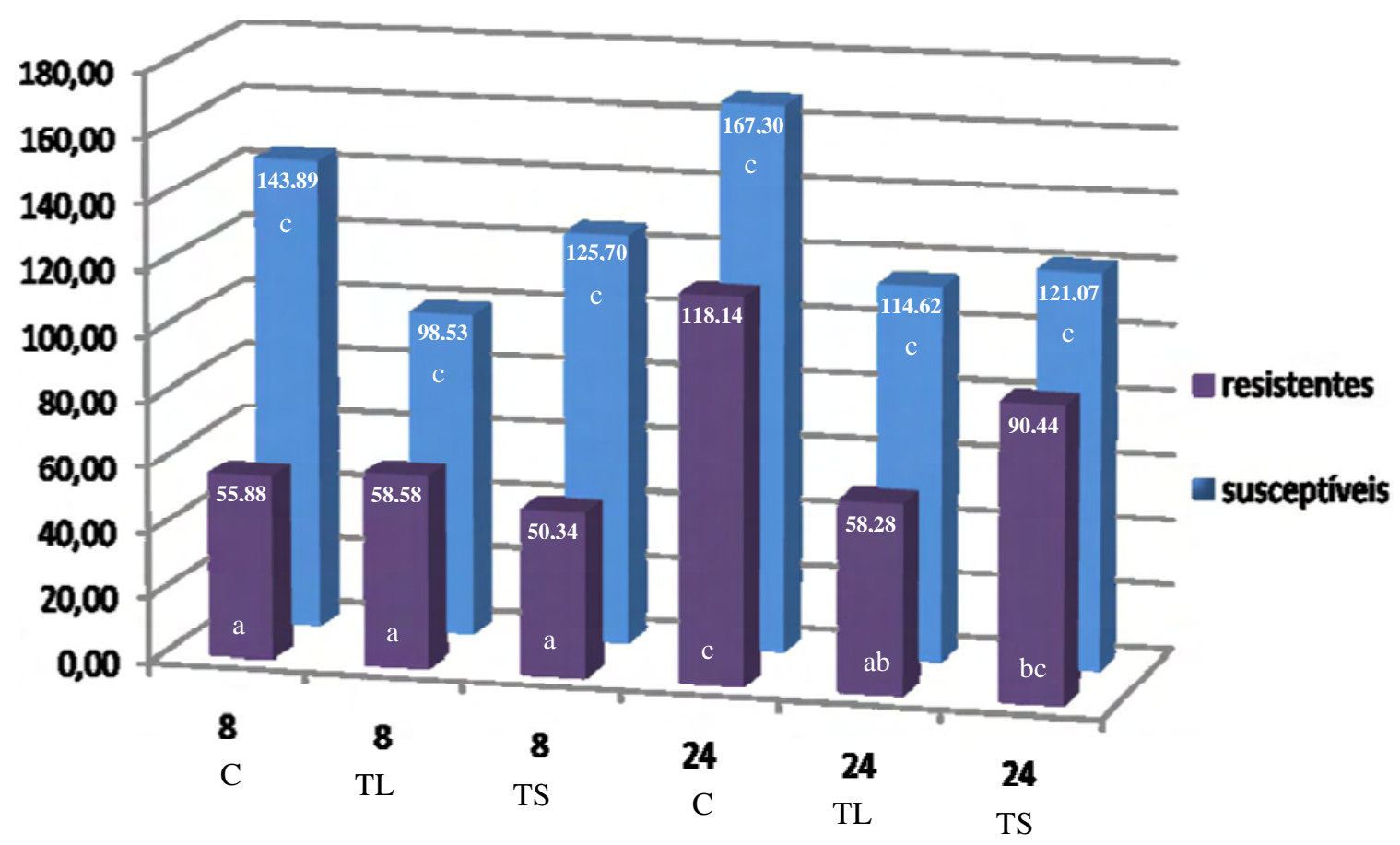

Figura 1. Valores médios para a concentração de óxido nítrico mensurada no fluído uterino livre de éguas resistentes e susceptíveis para os grupos controle (C), tratado local (TL) e tratado sistêmico (TS) nos momentos 8 e 24 horas após a inseminação artificial.

\section{DISCUSSÃO}

O processo inflamatório resultante do contato dos espermatozóides com o útero provoca alterações de permeabilidade dos vasos sanguíneos e liberação de fatores quimiotáticos que resultam em migração de neutrófilos para o local agredido (Palm et al, 2006). No presente trabalho foi verificado que anteriormente a inseminação artificial havia pequena presença de neutrófilos no lúmen uterino e após a introdução do sêmen ocorreu intensa migração deles, concordando com Troedsson et al. (2001) que sugeriram que os espermatozóides funcionam como agentes quimiotáticos para os PMNs. Independente do tratamento empregado ocorreu a migração neutrofílica para o útero, concordando com os achados de Bucca et al. (2008).

Foi observado neste estudo que as éguas resistentes apresentaram menor concentração de neutrófilos no fluído uterino do que as éguas 
susceptíveis a EPPC, discordando de relatos anteriores onde não foi constatada essa diferença (Liu et al., 1986; Williamson et al., 1987).

Apesar da diferença no pico da inflamação, onde um maior número de neutrófilos são encontrados (Katila, 1996), com o passar do tempo a concentração neutrofílica decresceu, tanto para as éguas resistentes como para as susceptíveis. Mas, mesmo com essa diminuição, a concentração de PMNs ainda se manteve maior para as éguas susceptíveis 24 horas após a inseminação artificial, concordando com os achados de Katila (1995).

Considerando que os neutrófilos no útero são mais efetivos na fagocitose do que aqueles que permanecem na corrente sanguínea por já estarem ativados no útero inflamado (Watson et al., 1987), que o tempo de vida de um neutrófilo varia de 12 a 15 horas (Katila, 1996) e que a presença do agente agressor no útero provoca um contínuo recrutamento dessas células (Liu et al., 1986), essa diferença na migração neutrofílica entre as éguas susceptíveis e resistentes pode ter sido resultante da contínua liberação de fatores quimiotáticos que facilitam a migração de neutrófilos para o útero (Troedsson, 1999), uma vez que as éguas susceptíveis apresentam maior expressão de interleucinas pró-inflamatórias após a cobertura do que as resistentes (Fumuso et al., 2003; Fumuso et al., 2006).

$\mathrm{O}$ tratamento local com dexametasona nas éguas resistentes permitiu similar influxo de neutrófilos para o lúmen uterino e, ao contrário do esperado, não permitiu redução na concentração dessas células semelhante a vista no grupo controle. Entretanto, o tratamento sistêmico proporcionou uma concentração de neutrófilos as 8 horas após a cobertura $60 \%$ menor em comparação ao grupo controle, mas as 24 horas os valores encontrados foram similares.

A dexametasona local não conseguiu manter a estabilidade da membrana vascular e minimizar o influxo de neutrófilos para o útero, provavelmente porque sua dose foi ajustada para induzir mínimas modificações na estrutura e nas características do movimento espermático, sendo portanto insuficiente na contenção da resposta inflamatória. Por outro lado, a aplicação sistêmica pode ter provocado menor liberação de fatores quimotáticos como as interleucinas, semelhante ao que foi observado por Fumuso et al (2006), pois a 
migração de neutrófilos para o lúmen uterino foi numericamente menor nesse grupo quando comparado aos grupos controle e tratado local.

Nas éguas susceptíveis os tratamentos com dexametasona minimizaram a migração de neutrófilos em um primeiro momento avaliado conferindo a imunomodulação desejada. Porém, 24 horas após a cobertura, o grupo controle apresentou menor quantidade dessas células de defesa. Entretanto, o número de animais usados no estudo impede que essa diferença numérica seja estatística. Além disso, foi observado que o tratamento sistêmico proporcionou menor redução na concentração de neutrófilos ao longo do período avaliado quando comparado com o grupo controle e com o tratado local. Isso pode ter acontecido porque as éguas susceptíveis apresentam uma resposta inflamatória diferenciada, uma vez que sua intensidade e duração são maiores.

A utilização da dexametasona nas éguas susceptíveis provoca um atraso na redução da concentração de PMNs no fluído uterino ao longo do tempo provavelmente porque a menor migração deles na fase inicial induza um atraso na limpeza uterina, sendo necessário um recrutamento contínuo de neutrófilos, concordando com os achados de Troedsson (1999). Essa diferença na resposta uterina pode estar vinculada a maior sensibilidade do útero aos sub-produtos inflamatórios, os corticóides podem ter bloqueado parcialmente a fosfolipase $A_{2}$ diminuindo a produção de ácido araquidônico, resultando na menor produção dos sub-produtos inflamatórios e menor migração neutrofílica.

Confirmando os achados de Bucca et al. (2008) e de Dell'aqua (2004), a terapia com corticóide não foi capaz de diminuir significativamente, apesar das diferenças numéricas, a concentração neutrofílica no líquido intra uterino de éguas resistentes e susceptíveis a EPPC.

Diversos autores constataram diferença entre as éguas susceptíveis e resistentes quanto a remoção mecânica do conteúdo uterino devido a variações contráteis do miométrio (Reitzenstein et al., 2002; Rigby et al., 2001; Nikolakopoulos et al., 2000b; Troedsson et al., 1993c). Além de outros fatores, essa menor atividade do miométrio apresentada pelas éguas susceptíveis está relacionada ao relaxamento muscular induzido pelo $\mathrm{ON}$, uma vez que sua alta concentração foi responsável por manter a atividade contrátil miometrial abaixo 
da linha basal entre 7 e 19 horas após a cobertura (Troedsson et al., 1993c). Assim sendo, a maior concentração de $\mathrm{ON}$ encontrada para as éguas susceptíveis 8 horas após a inseminação artificial pode ser responsabilizada pelo atraso na limpeza uterina favorecendo a persistência do processo inflamatório, concordando com os achados de Alghamdi e Troedsson (2002) que verificaram, 13 horas após a cobertura, que a concentração de $\mathrm{ON}$ foi significativamente menor nas éguas resistentes do que nas susceptíveis.

Foi constatado no presente trabalho que as éguas susceptíveis mantiveram altas concentrações de ON durante as primeiras 24 horas após a inseminação, esse fato deve estar relacionado ao elevado número de neutrófilos dispersos no lúmen uterino, uma vez que essa é uma característica marcante no útero inflamado dos animais com EPPC (Kotilainen et al., 1994), já que esse tipo de célula possui a capacidade de produzir ON (Wheeler et al., 1997; Alghamdi et al., 2005).

O uso da dexametasona local ou sistêmica não foi capaz de minimizar a produção e liberação de ON durante as primeiras 8 horas após a cobertura em comparação com o grupo controle. Entretanto, nas éguas resistentes após 24 horas da cobertura o tratamento com dexametasona local foi eficiente em manter a concentração de $\mathrm{ON}$ similar àquela encontrada as 8 horas. Uma vez que a iNOS foi detectada no endotélio vascular e na musculatura lisa do útero (Bulbul et al., 2007) e a dexametasona provoca a "downregulation" da sua expressão e, por consequênciua, uma diminuição na produção de ON no tecido endotelial (Ganster \& Geller, 2000), o contato direto dessa droga com o endométrio inflamado pode ter sido mais eficiente no combate a produção endotelial de ON.

Nas éguas resistentes ocorreu uma elevação da concentração de ON no transcorrer do período avaliado. Sendo o ON um subproduto inflamatório sua maior produção deveria ser compatível ao pico da inflamação, esse achado está em desacordo com os resultados obtidos por Katila (1996) que descrevem como pico da inflamação o intervalo entre 6 e 12 horas após a cobertura. $O$ aumento na concentração de ON observado as 24 horas foi um achado inesperado uma vez que grande parte dele é produzida pelos neutrófilos que estão no fluído uterino (Wheeler et al., 1997). Concordando com os achados de 
Katilla (1996) nossos resultados também demonstram uma diminuição da concentração de neutrófilos ao longo desse período, portanto seria esperado uma diminuição na concentração de $\mathrm{ON}$ concomitante a diminuição do processo inflamatório.

Apenas recentemente a presença de diferentes isoformas da NOS foi relatada no endométrio eqüino (Welter et al., 2004; Alghamdi et al., 2005) e o ON produzido no endométrio pode ter um efeito sobre o miométrio subjacente em qualquer fase do ciclo estral (Cameron \& Campbell, 1998), assim sendo, possivelmente 0 aumento verificado na concentração de $\mathrm{ON}$ não seja de responsabilidade dos neutrófilos, mas sim de outras células endometriais ou do sistema imune que estão infiltradas no endométrio.

De acordo com Alghamdi et al. (2005) todas as isoformas que controlam a produção de $\mathrm{ON}$ foram expressadas 13 horas após a inseminação artificial, porém em quantidade e localização diferentes, sendo que a expressão da iNOS foi maior em éguas susceptíveis. Essa maior expressão em éguas susceptíveis pode explicar a maior concentração de ON livre no fluído uterino dessas éguas 8 horas após a cobertura quando comparadas as éguas resistentes. Uma expressão tardia dessa enzima pode ser a responsável pelo aumento de ON 24 horas após a inseminação em éguas resistentes, estudos futuros seriam necessários para verificar a presença das isoformas da NOS no tecido uterino ou nas células inflamatórias nele infiltradas as 8 e as 24 horas após a cobertura e confirmar a diferença na expressão dessas enzimas entre as éguas resistentes e susceptíveis nesses momentos.

Embora os neutrófilos infiltrados no endométrio não demonstrem a capacidade de produzir ON por não exibirem nenhuma isoforma da NOS, a possibilidade de outras células de defesa presentes no endométrio contribuirem na sua produção não pode ser excluída (Alghamdi et al., 2005).

Outro fato que deve ser levado em consideração é que in vitro a síntese de ON pelo tecido endometrial equino é maior na fase lútea (Costa et al., 2007). O aumento na produção de ON na fase lútea pode ser explicado pela atividade enzimática da ciclooxigenase (COX) (Salvemini et al., 1993; Skarzynski et al., 2000). Portanto, o aumento da síntese de ON pelo endométrio eqüino durante a fase lútea pode também sugerir a participação do 
ON na regulação do fluxo sangüíneo e liberação de prostaglandinas no útero (Schmidt et al., 1992).

A expressão da eNOS no miométrio equino em todo o ciclo estral pode também sugerir um papel fisiológico semelhante ao da mulher e das ratas. $\mathrm{O}$ ON no miométrio da égua pode estar provocando a quiescência uterina para preparar o útero para a gestação (Costa et al., 2007). Uma possível explicação para o aumento do ON no fluído uterino livre nas éguas resistentes é a preparação do endométrio para receber o embrião, uma vez que, para essas éguas, 24 horas após a cobertura o processo inflamatório está praticamente finalizado e o útero estaria iniciando as modificações necessárias para a manutenção de uma gestação.

Finalmente podemos concluir que a concentração neutrofílica no lúmen uterino das éguas resistentes é inferior a das susceptíveis e que a utilização da dexametasona local e sistêmica não foi capaz de minimizar o influxo de neutrófilos após a cobertura. Para as éguas susceptíveis, a administração sistêmica de dexametasona foi responsável pelo atraso na redução da concentração neutrofílica entre 8 e 24 horas após a cobertura.

As éguas susceptíveis apresentaram maior concentração de óxido nítrico no fluído uterino 8 horas após a inseminação artificial quando comparadas as resistentes e mantiveram valores similares de concentração até as 24 horas. Entretanto, as éguas resistentes demonstraram aumento na concentração de $\mathrm{ON}$ das 8 para as 24 horas após a inseminação artificial.

Mais estudos são necessários para determinar as razões do aumento na concentração de ON 24 horas após inseminação artificial em éguas resistentes, pois aparentemente este aumento parece estar mais relacionado com outras células presentes no endométrio do que com a presença das células inflamatórias livres no fluído acumulado no lúmen uterino.

\section{REFERÊNCIAS BIBLIOGRÁFICAS}

Alghamdi, A.S.; Troedsson, M.H.T. 2002. Concentration of nitric oxide in uterine secretion from mares susceptible and resistant to chronic post-breeding endometritis. Theriogenology. 58, 445-448. 
Alghamdi, A.S.; Foster, D.N.; Carlson, C.S.; Troedsson, M.H.T. 2005. Nitric oxide levels and nitric oxide synthase expression in uterine samples from mares susceptible and resistant to persistent breeding-induced endometritis. Am. J. Reprod. Immuno. 53, 230-237

Al Hijii, J.; Larsson, I.; Batra, S. 2001. Effect of ovarian steroids on nitric oxide synthase in the rat uterus, cervix and vagina. Life Sci. 69, 1133-42.

Asbury, A.C.; Schultz, K.T.; Klesius, P.H.; Foster, G.N.; Washburn, S.M. 1982. Factors affecting phagocytosis of bacteria and neutrophils in the mare uterus. J. Reprod. Fertil. (Suppl). 32, 151-159.

Asbury, A.C. 1986. Endometritis in the mare. In: MORROW, D.A. (ED). Current therapy in theriogenology. 2.ed. Philadelphia: W.B. Saunders, pp. 718-722.

Bader H. 1982. An investigation of sperm migration into the oviducts of the mare. J. Reprod. Fertil. (Suppl). 32, 59-64.

Brinsko, S.P.; Varner, D.D.; Blanchard, T.L. 1991. The effect of uterine lavage performed four hours post-insemination on pregnancy rates in mares. Theriogenology. 35, 1111-1191.

Bulbul, A.; Yagcl, A.; Altunbas, K.; Sevimli, A.; Celik, H.A.; Karadeniz, A., Akdag, E. 2007. The role of nitric oxide in the effects of ovarian steroids on spontaneous myometrial contractility in rat. Theriogenology. 68, 1156-1168.

Bucca, S.; Carli, A.; Buckley; T.; Dolci, G., Fogarty, U. 2008. The use of dexamethasone administered to mares at breeding time in the modulation of persistent mating induced endometritis. Theriogenology. 70, 1093-1100.

Cadario, M.E.; Thatcher, W.W.; Klapstein, E.; Merrit, A.M.; Archbald, L.F.; Thatcher, M.J.; LeBlanc, M.M. 1999. Dynamics of Prostaglandin Secretion, 
intrauterine fluid and uterine clearance in reproductively normal mares and mares with delayed uterine clearance. Theriogenology. 52, 1181-1192.

Cameron, I.T.; Campbell, S. 1998. Nitric oxide in the endometrium. Human Reprod. Update. 4, 565-569.

Costa, R.P.R.; Ferreira-Dias, G.; Mateus, L.; Korzekwa, A.; Andronowska, A.; Platek, R.; Skarzynski, D.J. 2007. Endometrial nitric oxide production and nitric oxide synthases in the equine endometrium: Relationship with microvascular density during the estrous cycle. Dom. Anim. Endocrin. 32, 287-302.

Fioratti, E.G.; Melo, C.M.; Villaverde, A.I.S.B.; Papa, F.O.; Alvarenga, M.A. 2008. Effect of a steroidal anti-inflammatory drug on the viability of equine semen cooled for 24 hours. Reprod. Dom. Anim. 43, 102.

Fumuso, E.; Gigu`ere, S.; Wade, J.; Rogan, D.; Videla-Dorna, I.; Bowden, R. 2003. Endometrial IL-1, IL-6 and TNF- $\alpha$, mRNA expression in mares resistant or susceptible to post-breeding endometritis. Effects of estrous cycle, artificial insemination and immunomodulation. Vet. Immunol. Immunopathol. 96, 23-41.

Fumuso, E.; Aguilar, J.; Gigu`ere, S.; David, O.; Wade, J.; Rogan, D. 2006. Interleukin-8 (IL-8) and 10 (IL-10) mRNA transcriptions in the endometrium of normal mares and mares susceptible to persistent post-breeding endometritis. Anim. Reprod. Sci. 94, 282-285.

Galindo, A.S.D.; Kunz, T.L.; Gambarini, M.L.; Oliveira, B.D. 2003. Mecanismos de defesa uterinos na fêmea bovina. Rev. Cons. Fed. Med. Vet. 9, 49-58.

Ganster, R.W.; Geller, D.A. 2000. Molecular Regulation of Inducible Nitric Oxide Synthase. In: Ignarro, L.J. (ED). Nitric Oxide: Biology on Pathobiology. Academic Press, San Diego. 
Katila, T. 1995. Onset and duration of the uterine inflammatory response of mares after insemination with fresh semen. Biol. Reprod. Monograph. Series 1: Equine reproduction VI, 515-517.

Katila, T. Uterine defense mechanisms in the mare. 1996. Anim. Reprod. Sci. 42, 197-204.

Katila, T.; Sankari, S.; Mäkelä, O. 2000. Transport of spermatozoa in the reproductive tracts of mares. J. Reprod. Fertil. (suppl). 56, 571-8.

Knowles, R.G.; Palacios, M.; Palmer, R.M.; Moncada. S. 1989. Formation of nitric oxide from L-arginine in the central nervous system: a transduction mechanism for stimulation of the soluble guanylate cyclase. Proc. Acad. Sci. USA. 86, 5159-5162.

Kotilainen, T.; Huhtintn, M.; Katila, T. 1994. Sperm induced leukocytosis in the equine uterus. Theriogenology. 41, 629-636.

LeBlanc, M.M.; Neuwirth, L.; Mauragis, D.; Klapstein, E.; Tran, T. 1994. Oxytocin enhances clearance of radiocolloid from the uterine lumen of reproductively normal mares and mares susceptible to endometritis. Equine Vet. J. 26, 279-282.

Liu; I. K. M.; Cheung; A. T. W.; Walsh, E.M.; AYIN; S. 1986. The Functional Competence of Uterine-derived Polymorphonuclear Neutrophils (PMN) from Mares Resistant and Susceptible to Chronic Uterine Infection: A Sequential Migration Analysis. Biol. Reprod. 35, 1168-1174.

Losinno, L.; Alvarenga, M.A. 2006. Fatores críticos em programas de transferência de embriões em eqüinos no Brasil e Argentina. Acta Scientiae Veterinariae (Suppl 1). 34, 39-49. 
Moira, K.O.; Zini, A.; Cheng, C.Y.; Schlegel, P.N. 1998. Human sperm endothelial nitric oxide synthase expression: correlation with sperm motility. Fertil. Steril. 70, 1143-1147.

Murad, F. 1999. Cellular signaling with nitric oxide and cyclic GMP. Braz. J. Med. Biol. Res. 32, 1317-27.

Nathan, C. 1992. Nitric oxide as a secretory product of mammalian cells. Faseb J. 6, 3051-64.

Nikolakopoulos, E.; Kindahl, H.; Watson, E.D. 2000a. Oxytocin and PGF2 $\alpha$ release in mares resistant and susceptible to persistent mating-induced endometritis. J. Reprod. Fertil. (Suppl.) 56, 363-372.

Nikolakopoulos, E.; Kindahl, H.; Gilbert, C.L.; Goode; Watson, E.D. $2000 \mathrm{~b}$. Release of Oxytocin and Prostaglandin $f(2$ alpha) around teasing, natural service and associated events in the mare. Anim. Reprod. Sci. 63, 89-99.

Palm, F.; Walter, I.; Budik, S.; Aurich, C. 2006. Influence of different semen extenders and seminal plasma on the inflammatory response of the endometrium in oestrus mares. Anim. Reprod. Sci. 94, 286-289.

Rigby, S.L.; Barhoumi, R.; Burghardt, R.C.; Colleran, P.; Thompsom, J.A.; Varner, D.D; Blanchard, T.L.; Brinsko, S.P.; Taylor, T.; Wilkerson, M.K.; Delp, M.D. 2001. Mares with Delayed Uterine Clearance Have an Intrinsec Defect in Myometrial Function. Biol. Reprod. 65, 740-747.

Reitzenstein, M.; Callhan, M.A.; Hansen, P.J.; LeBlanc, M.M. 2002. Aberrations in uterine contractile patterns in mares with delayed uterine clearance after administration of detomidine and oxytocin. Theriogenology. 58, 887-898. 
Salvemini, D.; Misko, T.P.; Masferrer, J.L.; Seibert, K.; Currie, M.G., Needleman, P. 1993. Nitric oxide activates cyclooxygenase enzymes. Proc. Natl. Acad. Sci. USA. 90, 7240-7244.

Schmidt, H.H.W.; Gagne, G.D.; Nakane, M.; Pollock, J.S.; Miller, M.F.; Murad, F. 1992. Mapping of neural nitric oxide synthase in the rat suggests frequent colocalization with NADPH diaphorase but not with soluble guanylyl cyclase, and novel paraneural function for nitrinergic signal transduction. J. Hisotchem. Cytochem. 40, 1439-1456.

Scott, M.A.; Liu, I.K.M.; Overstreet, J.W. 1995. Sperm transport to the oviducts: Abnormality and their clinical implications. Proc. AAEP. 41, 1-2.

Skarzynski, D.J.; Kobayashi, S.; Okuda, K. 2000. Influence of nitric oxide and noradrenaline on prostaglandin F2 $\alpha$ induced oxytocin secretion and intracellular calcium mobilization in cultured bovine luteal cells. Biol. Reprod. 63, 10001005.

Troedsson, M.H.T.; deMoraes, M.J.; Liu, I.K.M. 1993a. Correlations between histologic endometrial lesions in mares and clinical response to intra-uterine exposure to Streptococcus zooepidemicus. Am. J. Vet. Res. 54, 570-572.

Troedsson, M.H.T.; Liu, I.K.; Thurmond, M. 1993b. Function of uterine and blood-derived polymorphonuclear neutrophils in mares susceptible and resistant to chronic uterine infection: phagocytosis and chemotaxis. Biol. Reprod. 49, 507-514.

Troedsson, M.H.T.; Liu, I.K.; Ing, M.; Pascoe, J.; Thurmond, M. 1993c. Multiple site electromyography recordings of uterine activity following an intrauterine bacterial challenge in mares susceptible and resistant to chronic uterine infection. J. Reprod. Fertil. 99, 307-313. 
Troedsson, M.H.T. 1995. Uterine response to semen deposition on the mare. In: Proceedings. The Annual Meeting of the Society for Theriogenology. 130135.

Troedsson, M.H.T.; Liu, I.K.M.; Ing, M.; Pascoe, J. 1995a. Smooth muscle electrical activity in the oviduct, and the effect of oxitocin, prostaglandin F2a and prostaglandin E2 on the myometrium and the oviduct of the cycling mare. Biol. Reprod. Monogr. 1, 475-488.

Troedsson, M.H.T.; Crabo, B.G.; Ibrahim, N.M.; Scott, M.; Ing, M. 1995b. Mating-induced endometritis: mechanisms, clinical importance, and consequences. Proc. AAEP. 41, 11-12.

Troedsson, M.H.T. 1997. Diseases of the uterus. In: Robinson, N.E. (ED). Current therapy in equine medicine. 4.ed. Philadelphia: W.B Saunders, pp. 517-524.

Troedsson, M.H.T. 1999. Uterine clearance and resistance to persistent endometritis in the mare. Theriogenology. 52, 461-471.

Troedsson, M.H.T.; Loseth, K.; Alghamdi, A.M.; Crabo, B.G. 2001. Interaction between equine semen and endometrium: the inflammatory response to semen. Proc. $3^{\text {rd }}$ Int. Symp. Stallion Reprod. 27.

Veronesi, M.C.; Carllucio, A.; Kindhal, H.; Faustini, M.; Battocchio, M.; Cairoli, F. 2006. Oxycitocin-induced PGF $2 \alpha$ Release in Mares With and Without Postbreeding Delayed Uterine Clearance. J. Vet. Med. 53, 259-262.

Watson, E.D.; Stokes, C.R.; Bourne, F.J. 1987. Cellular and humoral mechanisms in mares susceptible and resistant to persistent endometritis. Vet. Immunol. Immunopath. 6, 107-121. 
Welter, H.; Bollwein, H.; Weber, F.; Rohn, S., Einspanier, R. 2004. Expression of endothelial and inducible nitric oxide synthases is modulated in the endometrium of cyclic and early pregnant mares. Reprod. Fertil. Dev. 16, 689698.

Wheeler, M.A.; Smith, S.D.; Garcia-Cardena, G.; Nathan, C.F.; Weiss, R.M.; Sessa, W.C. 1997. Bacterial infection induces nitric oxide synthase in human neutrophils. J. Clin. Invest. 99, 110-116.

Yallampalli, C.; Garfield, R.E.; Byam-Smith, M. 1993. Nitric oxide inhibits uterine contractility during pregnancy but not during delivery. Endocrinology. 133, 1899-1902.

Zent, W.W.; Troedsson, M.H.T. 1998. Post breeding uterine fluid accumulation in a normal population of Thoroughbred mares: a field study. In: Proc. AAEP. 44, 64-5. 
Discussão Geral 


\section{DISCUSSÃO GERAL}

A acidez do ambiente uterino é deletéria ao movimento espermático, mas é uma condição reversível, ao contrário do prejuízo causado por um ambiente alcalino (MAKLER et al.,1981). Da mesma forma, mudanças osmóticas provocam redução da motilidade espermática irreversível (CRINCH \& JEQUIER, 1978). O espermatozóide equino apresenta baixa tolerância às variações de osmolaridade, e por essa razão, o diluidor para o sêmen deve apresentar uma pressão osmótica compatível a apresentada pelo ejaculado e o valor do $\mathrm{pH}$ deve ficar ao redor da neutralidade (BALL \& VO, 2001).

As suplementações com diversos AIES realizadas nesse estudo mantiveram $\circ \mathrm{pH}$ dos diversos meios extensores entre 6,63 a 6,95 e a osmolaridade permaneceu entre 351 e $392 \mathrm{mOsm} / \mathrm{Kg}$. Os resultados obtidos após a suplementação não demonstraram variações além daquelas estabelecidas como fisiológicas por Macedo et al (2003) e por Zahn et al (2001) e mantiveram a osmolaridade do diluidor seminal no intervalo de interesse estabelecido por Katila (1997). Portanto a queda de motilidade observada para a maioria das drogas utilizadas na suplementação do diluidor não pode ser creditada a alterações no $\mathrm{pH}$ e osmolaridade.

A motilidade é considerada um dos fatores mais importantes associados com a capacidade de fertilização do espermatozóide, pois a expressão dessa característica está diretamente relacionada à viabilidade e integridade estrutural da célula espermática (VERSTEGEN et al., 2002). Dessa forma, as drogas que induziram acentuada queda de motilidade foram excluídas do estudo e a dexametasona foi a droga eleita para ser utilizada como suplementação do diluidor no momento da inseminação artificial.

Entretanto, a capacidade fertilizante do espermatozóide também está vinculada com sua integridade morfofuncional. A integridade da membrana plasmática é fator de extrema necessidade para a sobrevivência do espermatozóide no trato reprodutivo feminino e para manutenção de sua capacidade fertilizante (PARKS \& GRAHAM, 1992). 
O contato direto entre a membrana dos espermatozóides e a dexametasona poderia provocar uma marcante estabilização dessa membrana plasmática impedindo, dessa forma, as modificações necessárias para a capacidade fertilizante. Porém, a habilidade de estabilizar membranas, e com isso imperdir a liberação de mediadores químicos pró inflamatórios, só pode ser observada em exposição a doses supra-farmacológicas de AIES, não se reproduzindo em doses terapêuticas convencionais. Dessa forma, dados obtidos nesse experimento demonstraram que a integridade da membrana espermática não foi alterada pelo contato com os AIES.

O acrossomo do espermatozóide deve permanecer intacto durante 0 carreamento desse pelo útero até o sítio de fertilização, pois a perda do acrossomo ou uma reação acrossomal espontânea os torna incapazes de exercer sua função de fertilização por não conseguirem se ligar a zona pelúcida e fertilizar o oócito (SILVA E GADELLA, 2006).

No presente experimento foi utilizada a associação FITC-PSA para verificar a integridade da membrana acrossomal e determinar se a suplementação com AIES seria capaz de induzir alguma modificação estrutural nela. Assim como na membrana plasmática, os resultados obtidos para a mensuração da integridade da membrana acrossomal demonstram que as interações com a dexametasona não produzem danos ao acrossomo.

Como citado anteriormente, as característica do movimento espermático são fundamentais para a fertilização, mas esse movimento está intimamente ligado ao funcionamento das mitocôndrias, uma vez que a porcentagem de mitocôndrias que se apresentam com funcionalidade normal está altamente correlacionada com a porcentagem de espermatozóides móveis e viáveis (GARNER et al., 1997; THOMAS et al., 1998). Em garanhões, uma relação entre função mitocondrial, motilidade e as características das velocidades têm sido observada (LOVE et al., 2003, PAPAIOANNOU et al., 1997).

Nesse trabalho foi considerada como ativada qualquer amostra que respondeu ao estímulo, não fazendo diferenciação entre as intensidades de resposta ou uma classificação dos espermatozóides baseada nesse parâmetro. Assim sendo, não foi verificada diferença significativa entre o grupo tratado com dexametasona e o controle no potencial da membrana mitocondrial. 
O acúmulo de líquido no lúmen uterino é decorrente da exsudação provocada pela inflamação e a passagem desse conteúdo traz consigo células de defesa, principalmente neutrófilos, para realizar junto com as contrações do miométrio e a drenagem linfática a limpeza uterina após a cobertura (TROEDSSON, 1999; KATILA, 1996).

No presente trabalho foi constatado que as éguas susceptíveis a endometrite pós cobertura acumulam maior quantidade de fluído intra uterino do que as éguas resistentes a esse processo persistente. Como observado por Dell'aqua (2004) a terapia com corticóide não foi capaz de diminuir o acúmulo de fluído intra uterino, discordando das observações de Bucca et al. (2008). Porém, a dexametasona sistêmica provocou uma maior redução do fluído acumulado das 8 para as 24 horas.

Foi observado neste estudo que as éguas resistentes apresentaram menor concentração de neutrófilos no fluído uterino do que as éguas susceptíveis a EPPC, discordando dos relatos de Liu et al. (1986) e Williamson et al. (1987). Mas, apesar das éguas resistentes e susceptíveis apresentarem diferentes concentrações de PMNs no pico da inflamação, com o passar do tempo a concentração de neutrófilos no lúmen uterino de ambas dimimuiu, observações condizentes com as de Katila (1996), porém a concentração de PMNs ainda se manteve maior para as éguas susceptíveis 24 horas após a inseminação artificial, concordando com os achados de Katila (1995).

Nas éguas susceptíveis os tratamentos com dexametasona diminuíram a migração de neutrófilos para o lúmen uterino 8 horas após a cobertura. Porém, 24 horas após a cobertura, o grupo que não foi submetido a qualquer tratamento apresentou menor quantidade absoluta dessas células, pois o tratamento sistêmico retardou o processo de redução do número de neutrófilos entre 8 e 24 horas após a cobertura.

A heterogenicidade dos neutrófilos uterinos pode comprometer a verificação de sua funcionalidade, uma vez que os neutrófilos derivados do útero são mais efetivos na fagocitose do que aqueles presentes na corrente sanguínea por já estarem ativados no útero inflamado (WATSON et al., 1987), porém Asbury et al. (1982) relataram que o fluído uterino das éguas susceptíveis provoca uma diminuição da capacidade opsonizante dos neutrófilos. Cheung et al. (1985) e Liu et al. (1986) relataram diferenças na 
capacidade de migração e fagocitose de neutrófilos de éguas resistentes e susceptíveis, mas observaram que os neutrófilos da corrente sanguínea possuem a mesma competência funcional para as duas classes de éguas, fato também observado por Dell'aqua (2004).

Ao verificar a funcionalidade neutrofílica, o presente estudo utilizou neutrófilos retirados diretamente do fluído uterino após sua coleta. Apesar da heterogenicidade populacional a capacidade fagocítica dessas células não apresentou diferença entre as éguas consideradas resistentes e susceptíveis a endometrite persistente, discordando dos achados de Asbury et al (1982) quanto a diferença verificada para éguas resistentes e susceptíveis.

No presente trabalho foi verificado que anteriormente a cobertura havia pequena presença de neutrófilos no lúmen uterino, concordando com Card et al (2004) e Nikolakopoulos \& Watson (2000) que relataram um baixo percentual de neutrófilos em éguas susceptíveis antes da cobertura, e após a introdução do sêmen ocorreu intensa migração deles, concordando com Troedsson et al. (2001) que sugeriram que os espermatozóides funcionam como agentes quimiotáticos para os PMNs. Independente do tratamento empregado ocorreu a migração neutrofílica para o útero, concordando com os achados de Bucca et al. (2008). Porém, todas as éguas resistentes apresentaram citologia compatível com o aceitável para o estro enquanto algumas das éguas susceptíveis apresentavam, nesse mesmo período, mais do que 5\% de neutrófilos, indicativo de inflamação ativa segundo Card (2005), apenas duas éguas susceptíveis apresentaram inflamação anteriormente à inseminação artificial, mas sem acúmulo de líquido no lúmen uterino.

As taxas de prenhez são inversamente proporcionais a intensidade da inflamação endometrial (RIDDLE et al., 2007). No presente trabalho foram encontradas taxas de recuperação embrionária para éguas resistentes de $73.33 \%$ e para éguas susceptíveis $33.33 \%$, demonstrando que a persistência da inflamação além das 24 horas após a cobertura é prejudicial a fertilidade dos animais.

Nas éguas resistentes, não foi constatada grande diferença na recuperação embrionária ao se empregar os tratamentos, concordando com Dell'aqua et al (2006). Porém, para as éguas susceptíveis, o tratamento com dexametasona local possibilitou um aumento de $40 \%$ na recuperção 
embrionária e o tratamento sistêmico duplicou o número de embriões recuperados por ciclo em comparação ao grupo controle, dados expressivos mesmo sem obtenção de diferença estatística que corroboraram os achados de Dell'aqua et al. (2006) e Bucca et al. (2008) que observaram aumento nos índices de fertilidade dos animais tratados com anti-inflamatórios esteróides.

Diversos autores constataram diferença entre as éguas susceptíveis e resistentes quanto a remoção mecânica do conteúdo uterino devido a variações contráteis do miométrio (REITZENSTEIN et al., 2002; RIGBY et al., 2001; NIKOLAKOPOULOS et al., 2000b; TROEDSSON et al., 1993). Além de outros fatores, essa menor atividade do miométrio apresentada pelas éguas susceptíveis está relacionada ao relaxamento muscular induzido pelo ON, uma vez que sua alta concentração foi responsável por manter a atividade contrátil miometrial abaixo da linha basal entre 7 e 19 horas após a cobertura (TROEDSSON et al., 1993). Assim sendo, a maior concentração de ON encontrada para as éguas susceptíveis 8 horas após a inseminação artificial pode ser responsabilizada pelo atraso na limpeza uterina favorecendo a persistência do processo inflamatório, concordando com os achados de Alghamdi \& Troedsson (2002) que verificaram, 13 horas após a cobertura, que a concentração de $\mathrm{ON}$ foi significativamente menor nas éguas resistentes do que nas susceptíveis.

Foi constatado no presente trabalho que as éguas susceptíveis mantiveram altas concentrações de ON durante as primeiras 24 horas após a inseminação, esse fato deve estar relacionado ao elevado número de neutrófilos dispersos no lúmen uterino, uma vez que essa é uma característica marcante no útero inflamado dos animais com endometrite (KOTILAINEN et al., 1994) e que essas células possuem capacidade de produzir ON (WHEELER et al., 1997; ALGHAMDI et al., 2005).

O uso da dexametasona local ou sistêmica não foi capaz de minimizar a produção e liberação de ON durante as primeiras 8 horas após a cobertura em comparação com o grupo controle. Porém, nas éguas resistentes após 24 horas da cobertura, o tratamento com dexametasona local foi eficiente em manter a concentração de $\mathrm{ON}$ similar àquela encontrada as 8 horas. 


\section{Conclusões Gerais}




\section{CONCLUSÕES GERAIS}

$\checkmark$ As características de motilidade espermática não se alteram após a adição de dexametasona ao diluidor de sêmen equino.

$\checkmark$ A integridade morfofuncional dos espermatozóides foi mantida apesar da adição da dexametasona ao diluidor de sêmen equino.

Após a inseminação artificial as éguas susceptíveis a endometrite persistente acumularam maior quantidade de líquido intra uterino com maior concentração de neutrófilos do que as éguas resistentes.

$\checkmark$ O teste do NBT verificou que não há diferença na capacidade fagocítica dos neutrófilos uterinos de éguas resistentes e susceptíveis à endometrite persistente após a cobertura.

$\checkmark$ Os tratamentos com dexametasona não foram deletérios para a funcionalidade dos neutrófilos do fluído uterino.

$\checkmark$ O exame citológico até 24 horas após a inseminação artificial é incapaz de diferenciar as éguas susceptíveis das resistentes a endometrite persistente após a cobertura.

$\checkmark$ Os tratamentos com dexametasona proporcionaram efeitos benéficos na redução do líquido acumulado no interior do útero e na taxa de recuperação embrionária.

As éguas susceptíveis apresentaram maior concentração de óxido nítrico no fluído uterino 8 horas, mas os valores se assemelham 24 horas após a inseminação artificial quando comparadas as resistentes a endometrite persistente. 
Bibliografia 


\section{BIBLIOGRAFIA}

ALGHAMDI, A.S., TROEDSSON, M.H.T. Concentration of nitric oxide in uterine secretion from mares susceptible and resistant of chronic post-breeding endometritis. Theriogenology. v.58, p. 445-448, 2002.

ALGHAMDI, A.S.; FOSTER, G.N., TROEDSSON, M.H.T. Nitric oxide levels and nitric oxide synthase expression in uterine samples from mares susceptible and resistant to persistent breeding-induced endometritis. Am. J. Reprod. Immunol., v.53, p.230-237, 2005.

ANDRADE, M.M.J. Antiinflamatórios Esteroidais. In: SPINOSA, H.S. Farmacologia aplicada à medicina veterinária. 3.ed. Rio de Janeiro: Guanabara-Koogan, 2002. p. 240-250.

ASBURY, A.C. Endometritis in the mare. In: MORROW, D.A. Current therapy in theriogenology. 2.ed. Philadelphia: W.B. Saunders, 1986. p. 718-722.

ASBURY, A.C. Failure of uterine defense mechanisms. In: ROBINSON, N.E. Current therapy in equine medicine. 2.ed. Philadelphia: W.B. Saunders, 1987. p. 508-511.

ASBURY, A.C.; SCHULTZ, K.T.; KLESIUS, P.H.; FOSTER, G.N.; WASHBURN, S.M. Factors affecting phagocytosis of bacteria and neutrophils in the mare uterus. J. Reprod. Fert. (Suppl). v. 32, p. 151-159, 1982.

BALL, B.A.; VO, A. Osmotic tolerance of equine spermatozoa and the effects of soluble cryoprotectants on equine sperm motility, viability, and mitochondrial membrane potential. J. Androl. v. 22, p. 1061-1069, 2001.

BIELANSKI, W.; RZASA, J.; OKOLSKI, A. Prostaglandins in stallion semen. Theriogenology, v.17, n.2, p.167-173, 1982. 
BRENDEMUEHL, J.P. Effect of Oxycitocin and PGF $2 \alpha$ on Luteal Formation, Function, and Pregnancy Rates in Mares. Theriogenology, v.58, p.623-626, 2002.

BUCCA, S.; CARLI, A.; BUCKLEY, T.; DOLCI, G., FOGARTY, U. The use of dexamethasone administered to mares at breeding time in the modulation of persistent mating induced endometritis . Theriogenology, v.70, p.1093-1100, 2008.

CADARIO, M.E.; MERRIT, A.M.; ARCHBALD, L.F.; THATCHER, W.W.; LEBLANC, M.M. Changes in intrauterine pressure after oxytocin administration in reproductively normal mares and those with a delay in uterine clearance. Theriogenology, v.51, p.1017-1025, 1999a.

CADARIO, M.E.; THATCHER, W.W.; KLAPSTEIN, E.; MERRIT, A.M.; ARCHBALD, L.F.; THATCHER, M.J.; LEBLANC, M.M. Dynamics of Prostaglandin Secretion, intrauterine fluid and uterine clearance in reproductively normal mares and mares with delayed uterine clearance. Theriogenology, v.52, p.1181-1192, 1999b.

CAMPBELL, M.H.L.; ENGLAND, G.C.W. A comparison of the ecbolic efficacy of intravenous and intrauterine oxytocin treatments. Theriogenology, v.58, p.437477, 2002.

CAMPBELL, M.H.L.; ENGLAND, G.C.W. Effect of teasing, mechanical stimulation and the intrauterine infusion of saline on uterine contractions in mares. Vet. Rec., v.155, p. 103-110, 2004.

CAMPBELL, M.H.L.; ENGLAND, G.C.W. The effect of coitus and artificial insemination of different volumes of fresh semen on uterine contractions in the mare. Anim. Reprod. Sci., v.94, p. 248-251, 2006. 
CARD, C. Infectious diseases of the puerperal period. In: YOUNGQUIST, R.S. Current therapy in large animal theriogenology. Philadelphia: W.B. Saunders, 1997. p.161-165.

CARD, C. Post-breeding inflammation and endometrial cytology in mares. Theriogenology, v.64, p. 580-588, 2005.

CARD, C.E.; CARLEY, S.D.; GREEN, J.; CHIRINO-TREJO, M. Endometrial cytology in mares bred with frozen semen. In: Proceedings of the 50th AAEP. 505-509, 2004.

CHENG, H.; ALTHOUSE, G.C.; HSU, W.H. Prostaglandin F2a added to extended boar semen at processing elicits in vitro myometrial contractility after 72 hours of storage. Theriogenology, v.55, p. 1901-1906, 2001.

CHENG, H.; ALTHOUSE, G.C.; HSU, W.H. Concentrations of endogenous prostaglandin F2alpha in boar semen and effect of a 72-h incubation period on exogenous prostaglandin F2alpha concentration in extended boar semen. Prostaglandins other lipid mediat. v.70, p.285-290, 2006.

CHEUNG, A.T.W; LIU, I.K.M.; WALSH, E.M.; MILLER, M.E. Phagocytic and killing capacity of uterine-derived polymorphonuclear leukocytes (PMNs) from mares resistant and susceptible to chronic endometritis. Am. J. Vet. Res. v. 46, p. 1938-1944, 1985.

CLAUS, R.; DIMMICK, M.A.; GIMENEZ, I; HUDSON, L.W. Estrogens and prostaglandin $F(2)$ alpha in the semen and blood plasma of stallions. Theriogenology. v.38, p.687-693, 1992.

CLOUGH. C.J.; CAMPBELL, M.L.H.; MATSON, T. The effect of inclusion of oxytocin in semen extender on spermatozoal motility. Anim. Reprod. Sci., v.94, p.132-134, 2006. 
COLLINS, T.; CONTRAN, R.S.; KUMAR, V. Robbins Pathologic Basic of Disease. $6^{\circ}$ ed., Ed WB Saunders, 1999.

CRINCH, J.P.; JEQUIER, A.M. Infertility in man with retrograde ejaculation: the action of purine on sperm motility, and a simple method for achieving antegrade ejaculation. Fertil. Steril. v. 30, p. 572-576, 1978.

DELL'AQUA Jr., J.A. Efeito da córtico-terapia e plasma seminal na resposta inflamatória e fertilidade de éguas submetidas à inseminação artificial. Botucatu, 2004. 120p. Tese (Doutorado) - Faculdade de Medicina Veterinária e Zootecnia - Universidade Estadual Paulista "Júlio de Mesquita Filho".

DELL'AQUA Jr., J.A.; PAPA, F.O.; LOPES, M.D., ALVARENGA, M.A.; MACEDO, L.P.; MELO, C.M. Modulation of acute uterine inflammatory response after artificial insemination with equine frozen semen. Anim. Reprod. Sci., v. 94, p. 270-273, 2006.

FISCHER, B.; BEIER, H.M. Uterine environment in early pregnancy. In: SCREENAN, J.M.; DISKIN, M.G. Embryonic mortality in farm animals. The Netherlands: Martinus Nijohoff Publishers, 1986. p.93-108.

GALINDO, A.S.D.; KUNZ, T.L.; GAMBARINI, M.L.; OLIVEIRA, B.D. Mecanismos de defesa uterinos na fêmea bovina. Revista do Conselho Federal de Medicina Veterinária, v.9, n.30, p. 49-58, 2003.

GALLAGHER, G.R.; SENGER, P.L. Effect of phenylephrine, ergonovine, oxytocin and norepinephrine as an extender ingredient on viability of bovine spermatozoa. J. Anim. Sci. v.67, p.1573-1576, 1989.

GARNER, D.L., THOMAS, C.A., JOERG, H.W., DELARNETTE, M., MARSHALL, C.E. Fluorometric Assessments of Mitochondrial Function and Viability in Cryopreserved Bovine Spermatozoa. Biology of Reproduction. v. 57, p. 1401-1406, 1997. 
GODDAR, P.J.; ALLEN, W.E. Genital tract pressures in mares II. Changes induced by oxytocin and prostaglandin $F(2)$ alpha. Theriogenology. v.24, p.3544, 1985.

GUTJAHR, S.; PACCAMONTI, D.L.; PYCOCK, J.F.; TAVERNE, M.A.M. DIELEMAN, S.J.; van der WEJDEN, G.C. Effect of dose and day of treatment on uterine response to oxytocin in mares. Theriogenology, v.54, p.447-456, 2000.

HINRICHS, K.; CUMMINGS, M.R.; SERTICH, P.L.; KENNEY, R.M. Clinical significance of aerobic bacterial flora of the uterus, vagina, vestibule, and clitoral fossa of clinically normal mares. J. Am. Vet. Med. Ass., v.193, p.72-75, 1988.

HOVART, G.; BILKEI, G. Exogenous prostaglandin F2 $\alpha$ at time of ovulation improves reproductive efficiency in repeat breeder sows. Theriogenology, v.59, p.1479-1484, 2003.

KATILA, T. Onset and duration of the uterine inflammatory response of mares after insemination with fresh semen. Biol. Reprod. Monograph. Series 1: Equine reproduction VI, p. 515-517, 1995.

KATILA, T. Uterine defense mechanisms in the mare. Anim. Reprod. Sci. v. 42, p. 197-204, 1996.

KATILA, T. Procedures for handling fresh stallion semen. Theriogenology. v. 46, p. 1217-1227, 1997.

KARAHAN, I. TURK, G.; GUR, S. In Vitro Effects of Prostaglandin F2 $\alpha$ and Metamizol on the Motility of diluted Bull Semen. Turk J. Vet. Anim. Sci., v.30, p.271-278, 2006.

KENNEY, R.M.; DOIG, P.A. Equine endometrial biopsy. In: MORROW, D.A. Current therapy in equine medicine. Philadelphia: W.B. Saunders, 1986. p.723729. 
KREIDER, J.L.; OGG, W.L.; TURNER, J.W. Influence of prostaglandin F $2 \alpha$ on sperm production and seminal characteristics of the stallion. Prostaglandins, v.22, p.903-913, 1981.

KOS, M.; BILKEI, G. Prostaglandin F 2alpha supplemented semen improves reproductive performance in artificially inseminated in sows. Anim. Reprod. Sci., v.80, p.113-120, 2004.

KOTILAINEN, T.; HUHTINTN, M.; KATILA, T. Sperm induced leukocytosis in the equine uterus. Theriogenology. v. 41, p. 629-636, 1994.

KOZUMPLIK, J.; MARTINEK, J. The effect of Oestrophan Spofa (synthetic analog of Prostaglandin F 2 alpha) added to the insemination dose on pregnancy and fertility in sows. Vet. Med. (Praha), v.31, p.227-232, 1986.

LEBLANC, M.M.; NEUWIRTH, L.; MAURAGIS, D.; KLAPSTEIN, E.; TRAN, T. Oxytocin enhances clearance of radiocolloid from the uterine lumen of reproductively normal mares and mares susceptible to endometritis. Equine Veterinary Journal. v.26, p.279-282, 1994.

LEBLANC, M.M. Effects of oxytocin, prostaglandin and phenylbutazone on uterine clearance of radiocolloid. Pferdeheilkunde, v.13, p.483, 1997.

LEBLANC, M.M. Persistent mating-induced endometritis. In: ROBINSON, N.E. Current therapy in equine medicine. 5.ed. St. Louis: Elsevier Science, 2003. p. 234-237.

LEFRANC, A.C., ALLEN, W.R. Uterine fluid accumulation and endometrial integrity in the barren mare. Pferdeheilkunde, v.24. p.27-30, 2008.

LIU; I. K. M.; CHEUNG; A. T. W.; WALSH, E.M.; AYIN; S. The Functional Competence of Uterine-derived Polymorphonuclear Neutrophils (PMN) from 
Mares Resistant and Susceptible to Chronic Uterine Infection: A Sequential Migration Analysis. Biol. Reprod. v. 35, p. 1168-1174, 1986.

LOVE, C.C., THOMPSON, J.A., BRINSKO, S.P., RIGBY, S.L., BLANCHARD, T.L., LOWRY, V.K., VARNER, D.D. Relationship between stallion sperm motility and viability as detected by two fluorescence staining techniques using flow cytometry. Theriogenology. v. 60(6), p. 1127-1138, 2003.

MACEDO, L.P., PAPA, F.O., MELO, C.M., DELL'AQUA JR, J.A. Efeito da sazonalidade sobre os parâmetros espermáticos de garanhões de diferentes raças na região de clima subtropical úmido (Botucatu, SP/ Brasil). Acta Scientiae Veterinariae. v. 31, p. 436, 2003.

MADILL, S.; TROEDSSON, M.H.T.; SANTSCHI, E.M.; MALONE, E.D. Doseresponse effect of intramuscular oxytocin treatment on myometrial contraction of reproductively normal mares during estrus. Theriogenology, v.58, p.479-481, 2002.

MAES, D.G.D.; MATEUSEN, B.; RIJSSELAERE, T.; DE VLIEGHER, S.; VAN SOOM, A.; de KRUIF, A. Motility characteristics of boar spermatozoa after addition of prostaglandin F2a. Theriogenology, v.60, p.1435-1443, 2003.

MAKLER, A.; DAVID, R.; BLUMENFELD, Z.; BETTER, O.S. Factors affecting sperm motility. VII Sperm viability as affected by change of $\mathrm{pH}$ and osmolarity of semen and urine specimen. Fertil. Steril. v. 36, p. 507-511, 1981.

MCRAE, A.C. The blood-uterine lumen barrier and exchange between extracelular fluids. J. Reprod. Fert., v.82, p.857-873, 1988.

MOIRA, K.O. Human sperm endothelial nitric oxide synthase expression: correlation with sperm motility. Fertil. Steril.,v.70, n.6, p.1143-1147, 1998. 
NIKOLAKOPOULOS, E.; WATSON, E.D. Uterine contractility is neLcessary for the clearance of intrauterine fluid but not bacteria after bacterial infusion in the mare. Theriogenology, v.52, p.413-423, 1999.

NIKOLAKOPOULOS, E.; WATSON, E.D. Effect of infusion volume and sperm numbers on persistence of uterine inflammation in mares. Equine. Vet. J. v. 32, p. 164-166, 2000.

NIKOLAKOPOULOS, E.; KINDAHL, H.; GILBERT, C.L.; GOODE; WATSON, E.D. Release of Oxytocin and Prostaglandin F2 $\alpha$ around teasing, natural service and associated events in the mare. Anim. Reprod. Sci., v.63, p.89-99, 2000.

O'BERT, H.; HARRIS, M.A.; ARNS, M.J. Prostaglandin F2 $\alpha$ concentrations in stallion semen and the effect of $24 \mathrm{~h}$ of cold storage on exogenous prostaglandin F2 $\alpha$ concentrations. Anim. Reprod. Sci., v.94, p.39-41, 2006.

PALM, F.; WALTER, I.; BUDIK, S.; AURICH, C. Influence of different semen extenders and seminal plasma on the inflammatory response of the endometrium in oestrus mares. Anim. Reprod. Sci., v.94, p.286-289, 2006.

PAPAIOANNOU, K.Z., MURPHY, R.P., MONKS, R.S., HYNES, N., RYAN, M.P., BOALND, M.P., ROCHE, J.F. Assessment of viability and mitochondrial function of equine spermatozoa using double staining and flow cytometry. Theriogenology. v. 48 (2), p. 299-312, 1997.

PARKS, E.J., GRAHAM, J.K. Effects of criopreservation procedures on sperm membranes. Theriogenology. v. 38, p. 209-222, 1992.

PENROD, L.; ADAMS, K.; ARNS, M.J. The influence of exogenous prostaglandin F2 $\alpha$ on spermatozoa motility and fertility. Anim. Reprod. Sci., v.94, p.36-38, 2006. 
PORTUS, B.J.; REILAS, T.; KATILA, T. Effect of plasma seminal on uterine inflammation, contractility and pregnancy rates in mares. Equine Vet. J., v.37, n.6, 2005.

REILAS, T.; RISCO, A.M.; KARESKOSKI, M.; KATILA, T. Effect of flunixin meglumine and oxytocin on uterine response to insemination in mares. Anim. Reprod. Sci., v.94, p.252-253, 2006.

REITZENSTEIN, M.; CALLHAN, M.A.; HANSEN, P.J.; LEBLANC, M.M. Aberrations in uterine contractile patterns in mares with delayed uterine clearance after administration of detomidine and oxytocin. Theriogenology, v.58, p.887-898, 2002.

RIDDLE, W.T.; LEBLANC, M.M.; STROMBERG, A.J. Relationships between uterine culture, cytology and pregnancy rates in a Thoroughbred practice. Theriogenology. v. 68, p. 395-402, 2007.

RIGBY, S.L.; HILL, J.; MILLER, C.; THOMPSON, J.; VARNER, D.; BLANCHARD, T. Administration of oxytocin immediately after insemination does not improve pregnancy rates in mares bred by fertile or subfertile stallions. Theriogenology, v.51, p.1143-1150, 1999.

RIGBY, S.L.; BARHOUMI, R.; BURGHARDT, R.C.; COLLERAN, P.; THOMPSOM, J.A.; VARNER, D.D; BLANCHARD, T.L.; BRINSKO, S.P.; TAYLOR, T.; WILKERSON, M.K.; DELP, M.D. Mares with Delayed Uterine Clearance Have an Intrinsec Defect in Myometrial Function. Biol. Reprod., v.65, p.740-747, 2001.

SILVA, P.N.F., GADELLA, B.M. Detection of damage in mammalian sperm cells. Theriogenology. v. 65, p. 958-978, 2006.

SINNEMAA, L.; JARVIMAA, T.; LEHMONEN, N.; MAKELA, O.; REILAS, T.; SANKARI, S.; KATILA, T. Effect of insemination volume on uterine contractions and inflammatory response and on elimination of sperm in the mare uterus - 
scintigraphic and ultrasonografic studies. J. Vet. Med. Assoc., v.52, p.466-471, 2005.

THOMAS, C.A., GARNER, D.L., DEJARNETTE, J.K., MARSHALL, C.E. Effect of Cryopreservation on Bovine Sperm Organelle Function and Viability as Determined by Flow Cytometry. Biology of Reproduction. v. 58, p. 786-793, 1998.

THOMASSIAN, A. Afecções do aparelho reprodutor da fêmea. In: Enfermidades dos cavalos. 3.ed. São Paulo: Livraria Varela, 1996. p.308-322.

THRELFALL, W.R.; CARLETON, C.L. Treatment of uterine infections in the mare. In: MORROW, D.A. Current therapy in theriogenology. 2.ed. Philadelphia: W.B. Saunders, 1986. p.730-736.

THRELFALL, W.R.; IMMEGART, H.M. Doença uterina e tratamento. In: REED, S.M.; BAYLY, W.M. Medicina interna eqüina. Rio de Janeiro: Editora Guanabara Koogan, 2000. p. 666-670.

TIZARD, I.R. Resistência às bactérias. In: . Imunologia veterinária. 5.ed. São Paulo: Editora Roca, 1998. p.294-309.

TROEDSSON, M.H.T.; LIU, I.K.; ING, M.; PASCOE, J.; THURMOND, M. Multiple site electromyography recordings of uterine activity following an intrauterine bacterial challenge in mares susceptible and resistant to chronic uterine infection. J. Reprod. Fertil. v. 99, p. 307-313, 1993.

TROEDSSON, M.H.T. Diseases of the uterus. In: ROBINSON, N.E. Current therapy in equine medicine. 4.ed. Philadelphia: W.B Saunders, 1997. p.517524.

TROEDSSON, M.H.T; LIU, I.K.M.; CRABO, B.G. Sperm transport and survival in the mare: a review. Theriogenology, v.50, p. 807-818, 1998. 
TROEDSSON, M.H.T. Uterine clearance and resistance to persistent endometritis in the mare. Theriogenology, v.52, p.461-471, 1999.

TROEDSSON, M.H.T.; LEE, C-S.; FRANKLIN, R.; CRABO, B.G. Post breeding uterine inflammation: the role of seminal plasma. J. Reprod. Fert., v.56, p.341$349,2000$.

TROEDSSON, M.H.T.; LOSET, k.; ALGHAMDI, A.M.; DAHMS, B.; CRABO, B.G. Interaction between equine semen and the endometrium: the inflamatory response to semen. Anim. Reprod. Sci., v.68, p.273-278, 2001.

TROEDSSON, M.H.T.; LOSETH, K.; ALGHAMDI, A.M.; DAHMS, B., CRABO, B.G. Interaction between equine semen and the endometrium: the inflammatory response to semen. Anim. Reprod. Sci., v.68, p.273-278, 2002.

TROEdsson, M.H.T.; DESVOUsGeS, A.; MACPHERSON, M.L., POZOR, M.P. Persistent breeding-induced endometritis. Pferdeheilkunde, v.24. p.56-60, 2008.

VERONESI, M.C.; CARLLUCIO, A.; KINDHAL, H.; FAUSTINI, M.; BATTOCCHIO, M.; CAIROLI, F. Oxycitocin-induced PGF $2 a$ release in mares with and without post-breeding delayed uterine clearance. J. Vet. Med., v.53, p.259-262, 2006.

VERSTEGEN, J., IGUER-OUADA, M., ONCLIN, K. Computer assisted semen analysers in andrology research and veterinary practice. Theriogenology. v. 57, p. $149-179,2002$.

WATSON, E.D.; STOKES, C.R.; BOURNE, F.J. Cellular and humoral mechanisms in mares susceptible and resistant to persistent endometritis. Vet. Immunol. Immunopath. v. 6, p. 107-121, 1987.

WATSON, E.D.; NIKOLAKOPOULOS, E.; GILBERT, C.; GOODE, J. Oxycitocin in the semen and gonads of stallion. Theriogenology, v.51, p.855-865, 1999. 
WHEELER, M.A.; SMITH, S.D.; GARCIA-CARDENA, G.; NATHAN, C.F.; WEISS, R.M.; SESSA, W.C. Bacterial infection induces nitric oxide synthase in human neutrophils. J. Clin. Invest. v. 99, p.110-116, 1997.

WILLENBURG, K.L.; MILLER, G.M; RODRIGUEZ-ZAS, S.L.; KNOX, R.V. Influence of hormone supplementation to extended semen on artificial insemination, uterine contractions, establishment of a sperm reservoir, and fertility in swine. Anim. Sci., v.81, p.821-829, 2003.

WILLIAMSON, P., MUNYA, S., MARTIN, R. AND PENHALE, J. Dynamics of the acute uterine response to infection, endotoxin infusion and physical manipulation of the reproductive tract in the mare. J. Reprod. Fertil. (Suppl.) v. 35, p. 317-325, 1987.

ZAHN, F.S., PAPA, F.O., DELL'AQUA JR, J.A., FERREIRA, J.C.P. Avaliação da variação sazonal de volume, motilidade, vigor, concentração, número total de espermatozóides, $\mathrm{pH}$ e osmolaridade do sêmen de garanhões na região e Botucatu. Ver. Bras. Reprod. Anim. v. 25, p. 201-203, 2001.

ZENT, W.W.; TROEDSSON, M.H.T. Post-breeding uterine fluid accumulation in a normal population of thoroughbred mares: a field study. Proc. Am. Assoc. Equine Pract., v.44, p.64-65, 1998. 


\section{Theriogenology An International J ournal of Animal Reproduction}

\section{Guide for Authors}

An International J ournal of Animal Reproduction

\section{NTRODUCTI ON}

Please consult this Guide for Authors for further details on the requirements for submitting your paper to Theriogenology. The guidelines described in this document should be adhered to carefully, to ensure high-quality and rapid publication of your manuscript.

Aims and Scope

Theriogenology is an international, peer-reviewed journal that publishes papers regarding the study of reproduction in domestic and non-domestic mammals, birds, reptiles, and fish. Theriogenology publishes only material that has never been previously published and is not being considered for publication elowhere; the exception would be limited disclosure (e.g. publication of an abstract or in the proceedings of a scientific conference, with limited circulation).

Types of Contribution
$1 . \quad$ Original Research Papers (Regular Papers)

1. $\quad$ Original Research

3. Technical Notes

Original Research Papers should report the results of original research. The material should not have been previously published elsewhere, except in a preliminary form.

Review Articles should cover subjects falling within the scope of the journal that are of active current interest. They are usually invited, but prospective Authors may contact the Editors with proposals.

Technical Notes are concise, comprehensive descriptions of technical aspects of innovative methods (that will not be subsequently published as a fulllength paper). The entire submitted manuscript typically should not exceed approximately 12 double-spaced pages.

Page Charges

This journal has no page charges.

\section{BEFORE YOU BEGIN}

Ethics in Publishing

For information on Ethics in Publishing and Ethical guidelines for journal publication see 6 http://www.elsevier.com/publishingethics and $\square$ http://www. elsevier.com/ethicalquidelines

Policy and Ethics

The work described in your article must have been carried out in accordance with The Code of Ethics of the World Medical Association (Declaration of Helsinki) for experiments involving humans: EC Directive 86/609/EEC for animal experiments; Uniform Requirements for manuscripts submitted to Biomedical iournals. This must be stated at an appropriate point in the article.

Conflict of Interest

All authors are requested to disclose any actual or potential conflict of interest including any financial, personal or other relationships with other people or organizations within three years of beginning the submitted work that could inappropriately influence, or be perceived to influence, their work. See also Ghattp://www.elsevier.com/conflictsofinterest

Submission Declaration

Submission of an article implies that the work described has not been published previously (except in the form of an abstract or as part of a published lecture or academic thesis), that it is not under consideration for publication elsewhere, that its publication is approved by all authors and tacitly or explicitly by the responsible authorities where the work was carried out, and that, if accepted, it will not be published elsewhere in the same form, in English or in any other language, without the written consent of the copyright-holder.

Contributors

Each author is required to declare his or her individual contribution to the article: all authors must have materially participated in the research and/or article preparation, so roles for all authors should be described. The statement that all authors have approved the final article should be true and included in the disclosu

Authorship

All authors should have made substantial contributions to all of the following: (1) the conception and design of the study, or acquisition of data, or analysis and interpretation of data, (2) drafting the article or revising it critically for important intellectual content, (3) final approval of the version to be submitted.

Copyright

Upon acceptance of an article, authors will be asked to complete a 'J ournal Publishing Agreement' (for more information on this and copyright see $\square$ the corresponding author confirming receipt of the manuscript together with a 'J ournal Publishing Agreement' form or a link to the online version of this agreement. Subscribers may reproduce tables of contents or prepare lists of articles including abstracts for internal circulation within their institutions. Permission of the Publisher is required for resale or distribution outside the institution and for all other derivative works, including compilations and translations (please consult G/http://www.elsevier.com/permissions). If excerpts from other copyrighted works are included, the author(s) must obtain written permission from the copyright owners and credit the source(s) in the article. Elsevier has preprinted forms for use by authors in these cases: please consult 日-lihttp://www.elsevier.com/permissions

Retained Author Rights

As an author you (or your employer or institution) retain certain rights; for details you are referred to: Ghttp://www.elsevier.com/authorsrights Role of the Funding Source

You are requested to identify who provided financial support for the conduct of the research and/or preparation of the article and to briefly describe the role of the sponsor(s), if any, in study design; in the collection, analysis and interpretation of data; in the writing of the report; and in the decision to submit the paper for publication. If the funding source(s) had no such involvement then this should be stated. Please see http://www.elsevier.com/funding 
Funding Body Agreements and Policies

Elsevier has established agreements and developed policies to allow authors whose articles appear in journals published by Elsevier, to comply with potential manuscript archiving requirements as specified as conditions of their grant awards. To learn more about existing agreements and policies please visit $\square$ http://www.elsevier.com/fundingbodies

Sponsored Articles

This journal offers authors the option to sponsor non-subscriber access to their articles on Elsevier's electronic publishing platforms. For more information please view our Sponsored Articles page at $\mathrm{G}$ http://www.elsevier.com/sponsoredarticles

Language Services

Authors who require information about language editing and copyediting services pre- and post-submission please visit

http://www.elsevier.com/languagepolishing or our customer support site at 6 http://epsupport.elsevier.com for more information. Please note Elsevier neither endorses nor takes responsibility for any products, goods or services offered by outside vendors through our services or in any advertising. For more information please refer to our Terms \& Conditions: Gluhttp://www.elsevier.com/termsandconditions

Submission

Submission to this journal proceeds totally online. Use the following guidelines to prepare your article. Via the online submission site of this journal ( $\square$ http://ees.elsevier.com/therio/ ) you will be guided stepwise through the creation and uploading of the various files. The system automatically converts source files to a single Adobe Acrobat PDF version of the article, which is used in the peer-review process. Please note that even though manuscript source files are converted to PDF at submission for the review process, these source files are needed for further processing after acceptance. All correspondence, including notification of the Editor's decision and requests for revision, takes place by e-mail and via the author's homepage, removing the need for a hard-copy paper trail.

Referees

Please submit, as part of the covering letter with the manuscript, the names, full affiliation (department, institution, city and country) and email addresses of up to 5 potential Referees. Appropriate Referees should be knowledgeable about the subject but have no close connection with any of the authors. In addition, Referees should be from institutions other than (and preferably countries other than) those of any of the Authors. You may also suggest reviewers you do not want to review your manuscript, but please state your reasons for doing so. The Editors retain the right to choose reviewers as deemed appropriate. All submissions will be reviewed by at least two anonymous reviewers to evaluate them for originality, clear statement of a hypothesis, appropriate experimental design, completeness of methods, a logical and comprehensive discussion, and conclusions that are supported by data.

\section{PREPARATION}

Language

Please write your text in good English (American or British usage is accepted, but not a mixture of these). Use decimal points (not decimal commas); use a space for thousands (10 000 and above).

Use of Word-processing Software

It is important that the file be saved in the native format of the word processor used. The text should be in single-column format and double spaced. It is important that all pages and lines are numbered. Keep the layout of the text as simple as possible. Most formatting codes will be removed and replaced on processing the article. In particular, do not use the word processor's options to justify text or to hyphenate words. However, do use bold face, italics, subscripts, superscripts etc. Do not embed "graphically designed" equations or tables, but prepare these using the word processor's facility. When preparing tables, if you are using a table grid, use only one grid for each individual table and not a grid for each row. If no grid is used, use tabs, not spaces, to align columns. The electronic text should be prepared in a way very similar to that of conventional manuscripts (see also the Guide to

Publishing with Elsevier: G-http://www.elsevier.com/guidepublication). Do not import the figures into the text file but, instead, indicate their approximate locations directly in the electronic text and on the manuscript. See also the section on Electronic illustrations. To avoid unnecessary errors you are strongly advised to use the "spell-check" and "grammar-check" functions of your word processor.

LaTeX

If the LaTeX file is suitable, proofs will be produced without rekeying the text. The article should preferably be written using Elsevier's document class "elsarticle", or alternatively the standard document class "article".

The Elsevier LaTeX style file package (including detailed instructions for LaTeX preparation) can be obtained from the Quickguide: $\square$ http://www.elsevier.com/latex. It consists of the file: elsarticle.cls, complete user documentation for the class file, bibliographic style files in various http://www. elsevier.com/latex. It consists

Article Structure

Subdivision - Numbered Sections

Divide your article into clearly defined and numbered sections. Subsections should be numbered 1.1. (then 1.1.1., 1.1.2., ...), 1.2., etc. (the abstract is not included in section numbering). Use this numbering also for internal cross-referencing: do not just refer to "the text". Any subsection may be given a brief heading. Each heading should appear on its own separate line, with one blank line above and below each heading.

Introduction

State the objectives of the work and provide an adequate background, avoiding a detailed literature survey or a summary of the results. In most cases, this section should not exceed approximately 2 double-spaced pages.

Materials and Methods

Provide sufficient detail to allow the work to be reproduced. Methods already published should be indicated by a reference: only relevant modifications should be described.

Results

Results should be clear and concise, and should correspond to data collection as described in Materials and Methods.

Discussion

This should explore the significance of the results of the work, not repeat them. A combined Results and Discussion section is often appropriate. Avoid extensive citations and discussion of published literature.

Conclusions

The main conclusions of the study may be presented in a short Conclusions section, which may stand alone or form a subsection of a Discussion or Results and Discussion section.

Essential Title Page Information

Title. Concise and informative. Titles are often used in information-retrieval systems. Avoid abbreviations and formulae where possible.

Author names and affiliations. Where the family name may be ambiguous (e.g., a double name), please indicate this clearly. Present the authors' affiliation addresses (where the actual work was done) below the names. Indicate all affiliations with a lower-case superscript letter immediately after the author's name and in front of the appropriate address. Provide the full postal address of each affiliation, including the country name, and, if available, the e-mail address of each author.

Corresponding author. Clearly indicate who is willing to handle correspondence at all stages of refereeing and publication, also post-publication. Ensure 
that telephone and fax numbers (with country and area code) are provided in addition to the e-mail address and the complete postal address.

Present/permanent address. If an author has moved since the work described in the article was done, or was visiting at the time, a "Present address"' (or "Permanent address") may be indicated as a footnote to that author's name. The address at which the author actually did the work must be retained as the main, affiliation address. Superscript Arabic numerals are used for such footnotes.

Abstract

A concise and factual abstract is required. The abstract should state briefly the purpose of the research, the principal results and major conclusions. An

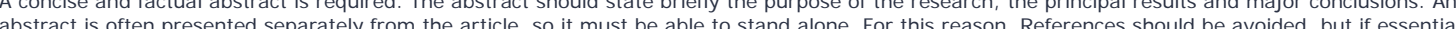
abstract is of must be defined at their first mention in the abstract itself.

Keywords

Immediately after the abstract, provide a maximum of 6 keywords, using American spelling and avoiding general and plural terms and multiple concepts (avoid, for example, "and", "of"). Be sparing with abbreviations: only abbreviations firmly established in the field may be eligible. These keywords will be used for indexing purposes.

Abbreviations

Define abbreviations that are not standard in this field in a footnote to be placed on the first page of the article. Such abbreviations that are unavoidable in the abstract must be defined at their first mention there, as well as in the footnote. Ensure consistency of abbreviations throughout the article.

Acknowledgements

Collate acknowledgements in a separate section at the end of the article before the references and do not, therefore, include them on the title page, as a footnote to the title or otherwise. List here those individuals who provided help during the research (e.g., providing language help, writing assistance or proof reading the article, etc.)

Nomenclature and Units

Follow internationally accepted rules and conventions: use the international system of units (SI). If other quantities are mentioned, give their equivalent in SI. You are urged to consult IUPAC: Nomenclature of Organic Chemistry:

Genbank

DNA sequences and GenBank Accession numbers. Many Elsevier journals cite "gene accession numbers" in their running text and footnotes. Gene accession numbers refer to genes or DNA sequences about which further information can be found in the databases at the National Center for Biotechnical Information (NCBI) at the National Library of Medicine. Authors are encouraged to check accession numbers used very carefully. An error in a letter or number can result in a dead link. Note that in the final version of the electronic copy, the accession number text will be linked to the appropriate source in the NCBI databases enabling readers to go directly to that source from the article.

Math Formulae Present simple formulae in the line of normal text where possible and use the solidus (/) instead of a horizontal line for small fractional terms, e.g., X/Y
In principle, variables are to be presented in italics. Powers of e are often more conveniently denoted by exp. Number consecutively any equations that In principle, variables are to be presented in italics. Powers of e are often more conve
have to be displayed separately from the text (if referred to explicitly in the text).

Footnotes

Footnotes should be used sparingly. Number them consecutively throughout the article, using superscript Arabic numbers. Many word processors build footnotes into the text, and this feature may be used. Should this not be the case, indicate the position of footnotes in the text and present the footnotes themselves separately at the end of the article. Do not include footnotes in the Reference list.

Table footnotes

Indicate each footnote in a table with a superscript lowercase letter.

Image Manipulation

Whilst it is accepted that authors sometimes need to manipulate images for clarity, manipulation for purposes of deception or fraud will be seen as scientific ethical abuse and will be dealt with accordingly. For graphical images, this journal is applying the following policy: no specific feature within an image may be enhanced, obscured, moved, removed, or introduced. Adjustments of brightness, contrast, or color balance are acceptable if and as long as they do not obscure or eliminate any information present in the original. Nonlinear adjustments (e.g. changes to gamma settings) must be disclosed in the figure legend.

Electronic Artwork

General points

- Make sure you use uniform lettering and sizing of your original artwork.

- Save text in illustrations as "graphics" or enclose the font.

- Only use the following fonts in your illustrations: Arial, Courier, Helvetica, Times, Symbol.

- Number the illustrations according to their sequence in the text.

- Use a logical naming convention for your artwork files.

- Provide captions to illustrations separately.

- Produce images near to the desired size of the printed version.

Submit each figure as a separate file.

A detailed guide on electronic artwork is available on our website: Ghttp://www.elsevier.com/artworkinstructions You are urged to visit this site; some excerpts from the detailed information are given here.

Formats

Regardless of the application used, when your electronic artwork is finalized, please "save as" or convert the images to one of the following formats Regardless of the application used, when your electronic artwork is finalized, please "save as" or convert the
(note the resolution requirements for line drawings, halftones, and line/halftone combinations given below):

EPS: Vector drawings. Embed the font or save the text as "graphics".

TIFF: color or grayscale photographs (halftones): always use a minimum of $300 \mathrm{dpi}$.

TIFF: Bitmapped line drawings: use a minimum of $1000 \mathrm{dpi}$.

TIFF: Combinations bitmapped line/half-tone (color or grayscale): a minimum of $500 \mathrm{dpi}$ is required. DOC, XLS or PPT: If your electronic artwork is created in any of these Microsoft Office applications please supply "as is".

Please do not:

- Supply embedded graphics in your word processor (spreadsheet, presentation) document;

- Supply files that are optimized for screen use (like GIF, BMP, PICT, WPG); the resolution is too low;

- Supply files that are too low in resolution; 
Non-Electronic Artwork

Provide all illustrations as high-quality printouts, suitable for reproduction (which may include reduction) without retouching. Number illustrations consecutively in the order in which they are referred to in the text. They should accompany the manuscript, but should not be included within the text. Clearly mark all illustrations on the back (or - in case of line drawings - on the lower front side) with the figure number and the author's name and, in cases of ambiguity, the correct orientation.

Mark the appropriate position of a figure in the article.

Color Artwork

Please make sure that artwork files are in an acceptable format (TIFF, EPS or MS Office files) and with the correct resolution. If, together with your accepted article, you submit usable color figures then Elsevier will ensure, at no additional charge, that these figures will appear in color on the Web (e.g. ScienceDirect and other sites) regardless of whether or not these illustrations are reproduced in color in the printed version. For color reproduction in print, you will receive information regarding the costs from Elsevier after receipt of your accepted article. Please indicate your preference for color in print or on the Web only. For further information on the preparation of electronic artwork, please see 1 http://www.elsevier.com/artworkinstructions. Please note: Because of technical complications which can arise by converting color figures to "gray scale" (for the printed version should you not opt for color in print) please submit in addition usable black and white versions of all the color illustrations.

Figure Captions

Ensure that each illustration has a caption. Supply captions separately, not attached to the figure. A caption should comprise a brief title (not on the figure itself) and a description of the illustration. Keep text in the illustrations themselves to a minimum but explain all symbols and abbreviations used.

Text Graphics

Present incidental graphics not suitable for mention as figures, plates or schemes at the end of the article and number them "Graphic 1", etc. Their precise position in the text can then be indicated. See further under Electronic artwork. If you are working with LaTeX and have such features embedded in the text, these can be left, but such embedding should not be done specifically for publishing purposes. Further, high-resolution graphics files must be provided separately.

Tables

Number tables consecutively in accordance with their appearance in the text. Place footnotes to tables below the table body and indicate them with superscript lowercase letters. Avoid vertical rules. Be sparing in the use of tables and ensure that the data presented in tables do not duplicate results described elsewhere in the article.

References

Citation in text

Please ensure that every reference cited in the text is also present in the reference list (and vice versa). Any references cited in the abstract must be given in full. Unpublished results and personal communications are not recommended in the reference list, but may be mentioned in the text. If these given in full. Unpublished results and personal communications are not recommended in the reference list, but may be mentioned in the text. If these publication date with either "Unpublished results" or "Personal communication" Citation of a reference as "in press" implies that the item has been publication date with either

Web references

As a minimum, the full URL should be given. Any further information, if known (DOI, author names, dates, reference to a source publication, etc.), should also be given. Web references can be listed separately (e.g., after the reference list) under a different heading if desired, or can be included in should also

References in a special issue

Please ensure that the words 'this issue' are added to any references in the list (and any citations in the text) to other articles in the same Special Issue.

Reference Style

Text: Indicate references by number(s) in square brackets in line with the text. The actual authors can be referred to, but the reference number(s) must always be given. Example: "..... as demonstrated $[3,6]$. Barnaby and Jones [8] obtained a different result..."

List: Number the references (numbers in square brackets) in the list in the order in which they appear in the text.

Examples:

Reference to a journal publication:

[1] Connor EE, Ashwell MS, Dahl GE. Characterization and expression of the bovine growth hormone-releasing hormone (GHRH) receptor. Domest Anim Endocrinol 2002;22:189-99.

Reference to a book:

[2] Van Zutphen LFM, Baumans V, Beynen AC. Principles of Laboratory Animal Science, Revised Edition. Elsevier B.V., 2001.

Reference to a chapter in an edited book:

[3] Betteridge KJ. Embryo Transfer. In: Reproduction in Domesticated Animals, King G] (Ed.), World Animal Science B9, Elsevier B.V., 1993, pp. 413-8.

Journal Abbreviations Source

Journal names should be abbreviated according to Index Medicus journal abbreviations: Ghttp://www.nlm.nih.gov/tsd/serials/lii.html; List of serial title word abbreviations: Ghhttp://www.issn.org/2-22661-LTWA-online.php; CAS (Chemical Abstracts Service): G Ghttp://www.cas.org/sent.htm/

Supplementary Material

Elsevier accepts electronic supplementary material to support and enhance your scientific research. Supplementary files offer the author additional possibilities to publish supporting applications, movies, animation sequences, high-resolution images, background datasets, sound clips and more. Supplementary files supplied will be published online alongside the electronic version of your article in Elsevier Web products, including ScienceDirect:

Whttp://www.sciencedirect.com In order to ensure that your submitted material is directly usable, please ensure that data are provided in one of our recommended file formats. Authors should submit the material in electronic format together with the article and supply a concise and descriptive caption for each file. Video files: please supply 'stills' with your files: you can choose any frame from the video or make a separate image. These will be used instead of standard icons and will personalize the link to your supplementary information. For more detailed instructions please visit our artwork instruction pages at Ghttp://www.elsevier.com/artworkinstructions

Additional Style Notes

Please use the following words, phrases, abbreviations, and stylistic conventions

- Avoid the word "injected," (e.g., "Cows were injected with cloprostenol") but include the generic name, proprietary name, dosage and route of administration (e.g., "Cows were treated with cloprostenol [Estrumate $500 \mu \mathrm{g} \mathrm{im]").}$

- Either cite a P value (recommended for Abstract and for Results) or use the term 'significant' (recommended for Discussion), but do not do both.

- Terms with a specific statistical meaning (i.e. significant, tended and correlated), should only be used in a strict statistical context.

- Numbers less than 10 are written as a word, unless followed by an abbreviation for unit of measure, e.g. five embryos, 5 min 
- transrectal palpation, not rectal palpation

- nucleus transfer, not nuclear transplant

- estrus (noun) synchronization, but, estrous (adjective) behavior

- $\quad$ sperm can be used as both noun and adjective

120 to 125 , not $120-125$

- treatment by period, not treatment $\mathrm{X}$ period

- gravity: $100 \mathrm{Xg}$ (in lieu of speed for centrifugation)

- magnification: $\times 100$

- identification number of an animal: No. 10, but 30 animals: $n=30$

- 3 d, Day 3 (define Day 0)

Standard definitions

- $\quad$ oogonium: female gamete before meiosis

- oocyte, primary: female gamete from onset of the first maturation division (meiosis) until extrusion of the first polar body

- oocyte secondary: female gamete from onset of second meiosis until extrusion of the second polar body

- ovum: female gamete from the end of both meiotic divisions until the union of the male and female pronuclei (differs from the common use of ovum as a general term for any female gamete)

- germinal vesicle: nucleus of the ovum

- zygote: a fertilized ovum, from the fusion of the male and female gamete to completion of first cleavage

- embryo: a conceptus from 2-cell stage to the stage when cell migration and differentiation are largely complete

- fetus: a conceptus after organogenesis is mostly complete (primarily increasing in size)

- conceptus: an embryo or fetus with all its membranes and accessory structures

- abortion: expulsion of a conceptus incapable of independent life

- premature parturition: expulsion (before full term) of a conceptus capable of independent life

- stillbirth: avoid this term (use fetal death or abortion)

Abbreviations

Never use an abbreviation to start a sentence. Some abbreviations may be used anywhere else, including the manuscript's title and figure and table titles and legends, without definition; others may not be used in the title, but may be used in the text without definition. In general, abbreviations must be defined when used for the first time (this may be avoided in the ABSTRACT if necessary to conserve space). To make reading the paper more pleasant, avoid using abbreviations and acronyms; instead use short synonyms, for instance: for "Cesarean section" instead of "CS" use "section" or "hysterotomy."

The following abbreviations may be used in the text without definition (note that abbreviations exclude periods):

$\begin{array}{lllll}\text { AI } & \text { ANOVA } & \text { ADP } & \text { ATP } & \text { BSA } \\ \text { cAMP } & \text { CL } & \text { DEAE-cellulose } & \text { DMSO } & \text { DNA } \\ \text { eCG } & \text { EDTA } & \text { EGF } & \text { ELISA } & \text { FSH } \\ \text { GH } & \text { GnRH } & \text { hCG } & \text { HEPE } & \text { ShMG } \\ \text { IVC } & \text { IVF } & \text { IVM } & \text { LH } & \text { MOET } \\ \text { MSH } & \text { mRNA } & \text { NAD } & \text { NADH } & \text { PBS } \\ \text { PGF } 2 \alpha & \text { PGFM } & \text { PIPES } & \text { PRID } & \text { PRL } \\ \text { RIA } & \text { RNA } & \text { SDS-PAGE } & \text { SCNT } & \text { TRH } \\ \text { TRIS } & \text { TRNA } & \text { TSH } & & \end{array}$

Units of Measure:

cpm - counts per min

$\mathrm{dpm}$ - disintegrations per min

- gram

ga - gauge of hypodermic needle

h- hour

$\mathrm{kg}$ - kilogram

L - liter

$\mathrm{mL}-$ milliliter

$\mathrm{mL}-$ milliiter

$\mathrm{m}$ - meter

min - minute

mo - month

sec - second

$\mathrm{v}: \mathrm{v}$ - volume ratio

wt/vol - weight per volume

$\mathrm{yr}$ - year

Routes of treatment:

id - intradermal

im - intramuscular

iu - intrauterine

iv - intravenous

po - oral

Statistical expressions:

ANOVA - analysis of variance

CV - coefficient of variation

$\mathrm{df}$ - degrees of fre
$\mathrm{F}$ - variance ratio

NS - not significant

P - probability

P - probability

SEM - standard error of the mean

SEM - standard error of the 
Additional information:

- For issues of style and format not addressed here, please consult Scientific Style and Format: The CBE Manual for Authors, Editors, and Publishers, Sixth Edition.

- For spelling, word formation and divisions, plurals, possessives, meanings and usage, consult the CBE Manual or a current English language collegiate-level dictionary.

- For conflicts between instructions in this Guide and any of the references, the Guide takes precedence. Do not hesitate to contact the Editorial Office if you have any questions about the preparation of your manuscript.

Submission Checklist

It is hoped that this list will be useful during the final checking of an article prior to sending it to the journal's Editor for review. Please consult this Guide for Authors for further details of any item.

Ensure that the following items are present:

One Author designated as corresponding Author

- E-mail address

- Full postal address

- Telephone and fax numbers

All necessary files have been uploaded

- Keywords

- All figure captions

- All tables (including title, description, footnotes)

Further considerations

- Manuscript has been "spellchecked" and "grammar-checked"

- References are in the correct format for this journal

- All references mentioned in the Reference list are cited in the text, and vice versa

- Permission has been obtained for use of copyrighted material from other sources (including the Web)

- color figures are clearly marked as being intended for color reproduction on the Web (free of charge) and in print or to be reproduced in color on the Web (free of charge) and in black-and-white in print

- If only color on the Web is required, black and white versions of the figures are also supplied for printing purposes

For any further information please visit our customer support site at $Q$ http://epsupport.elsevier.com

\section{AFTER ACCEPTANCE}

Use of the Digital Object Identifier

The Digital Object Identifier (DOI) may be used to cite and link to electronic documents. The DOI consists of a unique alpha-numeric character string which is assigned to a document by the publisher upon the initial electronic publication. The assigned DOI never changes. Therefore, it is an ideal medium for citing a document, particularly 'Articles in press' because they have not yet received their full bibliographic information.

The correct format for citing a DOI is shown as follows (example taken from a document in the journal Physics Letters B):

doi: 10.1016/j. physletb. 2003.10.071

When you use the DOI to create URL hyperlinks to documents on the web, they are guaranteed never to change.

Proofs

One set of page proofs in PDF format will be sent by e-mail to the corresponding author (if we do not have an e-mail address, then paper proofs will be sent by post). Elsevier now sends PDF proofs which can be annotated; for this you will need to download Adobe Reader version 7 (or higher) available free from Ghttp://www.adobe.com/products/acrobat/readstep2.html Instructions on how to annotate PDF files will accompany the proofs. The exact system requirements are given at the Adobe site: 1 http://www.adobe.com/products/acrobat/acrrsystemreqs. html\# 70 win

If you do not wish to use the PDF annotations function, you may list the corrections (including replies to the Query Form) and return to Elsevier in an email. Please list your corrections quoting line number. If, for any reason, this is not possible, then mark the corrections and any other comments (including replies to the Query Form) on a printout of your proof and return by fax, or scan the pages and e-mail, or by post. Please use this proof only for checking the typesetting, editing, completeness and correctness of the text, tables and figures. Significant changes to the article as accepted for publication will only be considered at this stage with permission from the Editor. We will do everything possible to get your article published quickly and accurately. Therefore, it is important to ensure that all of your corrections are sent back to us in one communication: please check carefully before replying, as inclusion of any subsequent corrections cannot be guaranteed. Proofreading is solely your responsibility. Note that Elsevier may proceed with the publication of your article if no response is received.

Offprints

The corresponding author, at no cost, will be provided with a PDF file of the article via e-mail. The PDF file is a watermarked version of the published article and includes a cover sheet with the journal cover image and a disclaimer outlining the terms and conditions of use.

\section{AUTHOR INQUIRIES}

For inquiries relating to the submission of articles (including electronic submission where available) please visit this journal's homepage. You can track accepted articles at $\$$ http://www.elsevier.com/trackarticle and set up e-mail alerts to inform you of when an article's status has changed. Also accessible from here is information on copyright, frequently asked questions and more. Contact details for questions arising after acceptance of an article, especially those relating to proofs, will be provided by the publisher.

Updated March 2009

This is a spacer.

Top of Page 